\title{
The Judicial Genealogy (and Mythology) of John Roberts: Clerkships from Gray to Brandeis to Friendly to Roberts
}

\begin{abstract}
BRAD SNYDER*
During his Supreme Court nomination hearings, John Roberts idealized and mythologized the first judge he clerked for, Second Circuit Judge Henry Friendly, as the sophisticated judge-as-umpire. Thus far on the Court, Roberts has found it difficult to live up to his Friendly ideal, particularly in several high-profile cases. This Article addresses the influence of Friendly on Roberts and judges on law clerks by examining the roots of Roberts's distinguished yet unrecognized lineage of former clerks: Louis Brandeis's clerkship with Horace Gray, Friendly's clerkship with Brandeis, and Roberts's clerkships with Friendly and Rehnquist. Labeling this lineage a judicial genealogy, this Article reorients clerkship scholarship away from clerks' influences on judges to judges' influences on clerks. It also shows how Brandeis, Friendly, and Roberts were influenced by their clerkship experiences and how they idealized their judges. By laying the clerkship experiences and career paths of Brandeis, Friendly, and Roberts side-byside in detailed primary source accounts, this Article argues that judicial influence on clerks is more professional than ideological and that the idealization of judges and emergence of clerkships as must-have credentials contribute to a culture of judicial supremacy.
\end{abstract}

* Assistant Professor, University of Wisconsin Law School. Thanks to Eleanor Brown, Dan Ernst, David Fontana, Abbe Gluck, Dirk Hartog, Dan Hamilton, Alison LaCroix, Brent McIntosh, Jeff Rosen, Mitra Sharafi, Dan Sharfstein, Frank Tuerkheimer, Mel Urofsky, Bill Whitford, John Witt, and the participants at the American Bar Foundation/Illinois Legal History Seminar, University of Wisconsin Law School junior faculty workshop, and George Washington University Law School faculty workshop for their comments; to Philip Bobbitt, Judge Michael Boudin, Charles Davidow, Peter Edelman, Andrew Kaufman, Reinier Kraakman, Larry Kramer, Richard Lazarus, Judge Pierre Leval, and Paul Mogin for their input and for agreeing to be interviewed; to Joan Goodman for providing me with her father's oral history transcripts; to Jill Bramwell and Tim Lundquist for their research assistance; to Jessica H. Kim and her colleagues at the Ohio State Law Journal; and to the following librarians and archivists: Lilly Li, Cheryl O'Connor, and Bonnie Shucha at the University of Wisconsin Law Library; Lia Apodaca, Fred Augustyn, Jennifer Brathovde, Jeff Flannery, Patrick Kerwin, Bruce Kirby, Joe Jackson, and Daun van Ee at the Library of Congress Manuscript Division; Dave Kelly at the Library of Congress; Ed Moloy, Margaret Peachy, Lesley Schoenfeld, and David Warrington at the Harvard Law School Special Collections Library; and Barbara Krieger at Dartmouth College's Rauner Library archives. 


\section{TABLE OF CONTENTS}

I. INTRODUCTION

II. THE GRAY CLERKSHIP: 1875-1902 …....................................... 1157

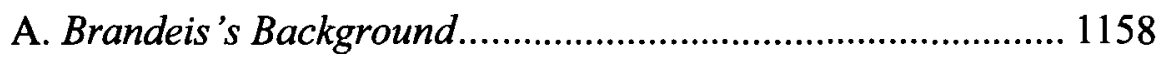

B. Brandeis's Clerkship Experience ...................................... 1159

III. THE BRANDEIS CLERKSHIP: 1916-1939 ................................... 1161

A. The Courtship of Henry Friendly ............................................ 1166

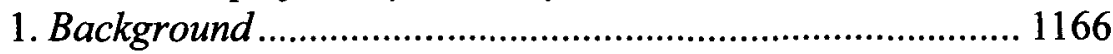

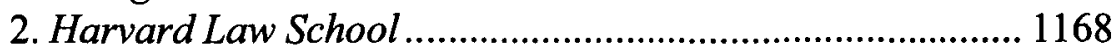

3. The Battle with Buckner ................................................... 1171

B. Friendly's Clerkship Experience............................................ 1174

IV. BRANDEIS'S INFLUENCE ON FRIENDLY ..................................... 1189

A. Friendly's Career Choices.................................................. 1190

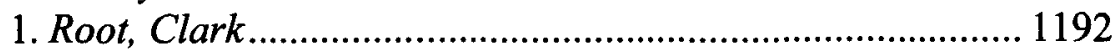

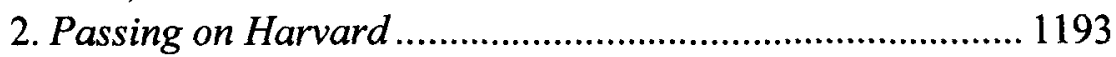

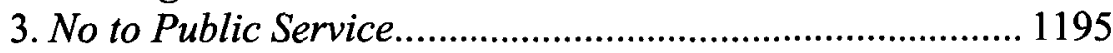

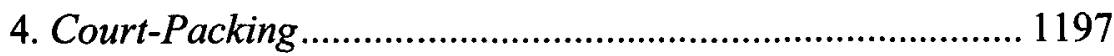

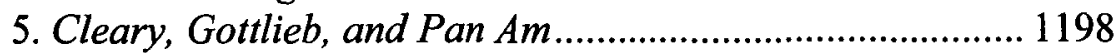

6. Calling on the Second Circuit ............................................. 1199

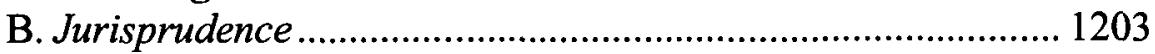

C. Clerkship Model ................................................................. 1209

V. THE FRIENDLY CLERKSHIP, 1959-1986_................................. 1215

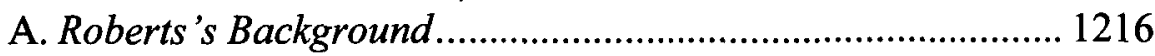

B. Roberts's Clerkship Experience ............................................. 1219

C. Roberts's Career Path.......................................................... 1221

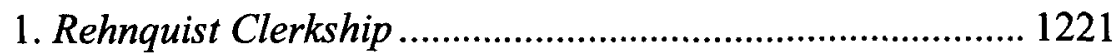

2. Reagan Justice Department ............................................. 1225

3. Hogan \& Hartson ........................................................... 1228

4. Principal Deputy Solicitor General .................................... 1228

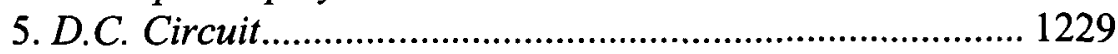

VI. FRIENDLY MYTHOLOGY REVISITED........................................ 1231

A. Friendly as Umpire .............................................................. 1234

B. Friendly as Unattainable Ideal ........................................... 1235

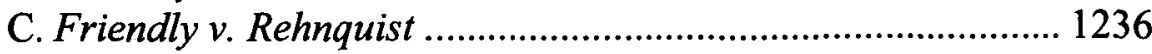

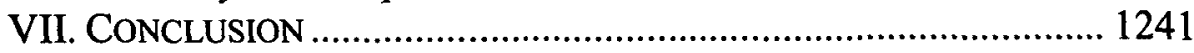

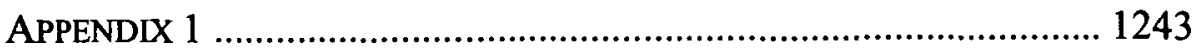




\section{INTRODUCTION}

In 2005, John G. Roberts nearly made American judicial history as the first former law clerk to join his Justice on the Supreme Court. Instead, Roberts helped carry Chief Justice William Rehnquist's "plain unvarnished pine" coffin up the Court's marble steps ${ }^{1}$ and succeeded Rehnquist as Chief Justice. Conventional wisdom pegged Roberts as a Rehnquist disciple. ${ }^{2}$ Most commentators, however, overlooked Roberts's clerkship with one of the Nation's most revered federal appellate judges - Second Circuit Judge Henry J. Friendly. ${ }^{3}$ To Bush Administration officials, friends, and law clerks, Roberts identified Friendly, not Rehnquist, as his judicial role model. ${ }^{4}$

During his Supreme Court confirmation hearings, Roberts described Friendly as the exemplar of judicial modesty. ${ }^{5}$ Roberts admired that Friendly was not results-oriented and that the media could not decide whether Friendly was liberal or conservative. ${ }^{6}$ Roberts admired the thoroughness of Friendly's opinions and that, despite being an "absolute genius," Friendly possessed the "essential humility" to defer to elected officials.

Roberts regarded Friendly as the ideal judge. For the American public, Roberts explained his judicial philosophy through his much maligned judges-

1 John G. Roberts, Jr., Tribute to William H. Rehnquist, 31 J. SuP. CT. Hist. 15, 15 (2006); see also JEFFREY TOOBIN, THE NINE 3 (2007).

2 Tom Brune \& Monte R. Young, His Conservative Roots Run Deep, NEwSDAY, July 24, 2005, at A7; Jan Crawford Greenburg, Philosophy Likely to Evoke Rehnquist, CHI. TRIB., Sept. 6, 2005, at 1; Adam Liptak \& Todd S. Purdum, As Clerk for Rehnquist, Nominee Stood Out for Conservative Rigor, N.Y. TLMES, July 31, 2005, at 1; Tony Mauro, Editorial, Ironies Abound as Rehnquist Leaves Us, USA TODAY, Sept. 7, 2005, at $25 \mathrm{~A}$.

${ }^{3}$ But see Todd S. Purdum et al., Court Nominee's Life Is Rooted in Faith and Respect for Law, N.Y. TIMES, July 21, 2005, at 1 (comparing Roberts to Friendly because "Roberts is an erudite, Harvard-trained, Republican corporate-lawyer-turned-judge, with a punctilious, pragmatic view of the law"); Jeffrey Rosen, Op-Ed., In Search of John Roberts, N.Y. TIMES, July 21, 2005, at A21 (encouraging Senators to ask questions about Friendly during Roberts's confirmation hearings).

${ }^{4}$ Author Interviews; Michael Grunwald \& Amy Goldstein, Few Have Felt Beat of Roberts's Political Heart, WASH. PosT, July 24, 2005, at Al (quoting Roberts's friend Richard Lazarus); Neil Lewis, An Ultimate Capital Insider, N.Y. TIMES, July 20, 2005, at A14 (also quoting Richard Lazarus).

${ }^{5}$ Confirmation Hearing on the Nomination of John G. Roberts, Jr. to Be Chief Justice of the United States: Hearing Before the S. Comm. on the Judiciary, 109th Cong. 202 (2005) [hereinafter Roberts Supreme Court Hearings] (statement of John Roberts).

${ }^{6}$ Id.

${ }^{7}$ Id. 
as-baseball umpires metaphor. ${ }^{8}$ For members of the Senate Judiciary Committee, Roberts offered them a more sophisticated judicial umpire in Henry Friendly.

During Roberts's first five years as Chief Justice, Friendly has been less a role model than an unattainable ideal. Roberts and Friendly served on different courts and judged in different eras. Nor is it fair to judge Roberts on a handful of high-profile cases or five years into his Supreme Court tenure. Thus far, Roberts has not attained Friendly's reputation as a sophisticated judicial umpire. It remains an elusive goal.

Law clerks have been mythologizing their judges for generations. Indeed, Roberts is part of a distinguished and unrecognized lineage of former law clerks who have idealized their judges beginning with Louis Brandeis's clerkship with Horace Gray from 1877 to 1879 , continuing with Henry Friendly's clerkship with Brandeis from 1927 to 1928, and culminating with Roberts's clerkships with Friendly and Rehnquist from 1978 to $1980 .{ }^{9}$

This Article refers to Roberts's clerkship lineage as a judicial genealogy because clerks often think of themselves as extended families of Brandeis clerks, Friendly clerks, or Rehnquist clerks. With more federal judges beginning their legal careers as clerks, ${ }^{10}$ these extended clerkship families span multiple generations. If history is any indication, more than one-third of Obama's judicial nominees will be former judicial clerks. ${ }^{11}$ Obama's second Supreme Court nominee, Elena Kagan, clerked for D.C. Circuit Judge Abner Mikva and Justice Thurgood Marshall. At her Supreme Court confirmation hearings, Republican Senators criticized Mikva and Marshall as "well-known activists" 12 and charged that Kagan's clerkship memos to Marshall indicate

${ }^{8}$ See, e.g., Aaron Zelinsky, The Justice as Commissioner: Benching the JudgeUmpire Analogy, 119 YALE L.J. POCKET PART 113, 116-17 (2010), http://yalelawjournal.org/2010/03/03/zelinsky.html; $c f$. BRUCE WEBER, AS THEY SEE 'EM 172 (2009) (quoting umpire describing calling of balls and strikes as "like the Constitution" and "[t]he strike zone is a living, breathing document" and another umpire about the rulebook's description of the strike zone: "Have you ever read Roe $v$. Wade? What it says is very clear. And we've still been fighting for twenty-five or thirty years over what it means.").

${ }^{9}$ Roberts could be considered part of another judicial genealogy. Rehnquist clerked for Justice Robert Jackson, one of Roberts's favorite justices. Rehnquist, however, was not one of Jackson's favorite clerks and misread Jackson's views, particularly when it came to Brown v. Board of Education. See Brad Snyder, What Would Justice Holmes Do (WWJHD)?: Rehnquist's Plessy Memo, Majoritarianism, and Parents Involved, 69 OHо ST. L.J. 873, 882-89 (2009).

${ }^{10}$ See infra, app. 1.

11 Id.

12 See Confirmation Hearing on the Nomination of Elena Kagan to be Associate Justice of the United States: Hearing Before the S. Comm. on the Judiciary, 111 th Cong. (2010) [hereinafter Kagan Supreme Court Hearings] (statement of Sen. Jeff Sessions). 
that she was results-oriented "based largely on her own liberal policy preferences." 13 Kagan responded that "the role of the clerks was pretty much to channel Justice Marshall" and that "if you confirm me to this position, you will get Justice Kagan. You won't get Justice Marshall."14

Through the concept of judicial genealogy, this Article hopes to reorient clerkship scholarship. Scholars have focused on the influence of clerks on their judges. ${ }^{15}$ Backlash over Brown v. Board Education (and other Warren Court decisions) ${ }^{16}$ and Bush v. Gore ${ }^{17}$ and clerk-centric books about the Court ${ }^{18}$ have increased anxiety about clerk influence.

The obsession with law clerk influence is greater than ever. A recent article analyzed the "separate career tracks" of liberal and conservative

${ }^{13}$ Id. (statement of Sen. Jon Kyl).

${ }^{14}$ Id. (statement of Elena Kagan). For similar comments about Marshall, see generally Confirmation Hearing on the Nominations of Thomas Perrelli Nominee to be Associate Attorney General of the United States and Elena Kagan Nominee to be Solicitor General of the United States, Hearing Before the S. Comm. on the Judiciary, 111 th Cong. 97-99 (2009) [hereinafter Kagan S.G. Hearings]; Elena Kagan, For Justice Marshall, 71 TEX. L. REV. 1125 (1992).

15 See generally Bradley J. Best, LAW Clerks, Support PersonNel, aNd tHE DEClINE OF CONSENSUAL NORMS ON THE UNITED STATES SUPREME COURT, 1935-1995 (2002); TODD C. PEPPERS, COURTIERS OF THE MARBLE PALACE: THE RISE AND INFLUENCE OF THE SUPREME COURT LAW Clerk (2006); ARTEMUS WARD \& DAVID L. WEIDEN, SORCERERS' APPRENTICES (2006); Helen J. Knowles, Clerkish Control of Recent Supreme Court Opinions? A Case Study of Justice Kennedy's Opinion in Gonzales v. Carhart, 10 Geo. J. GENDER \& L. 63 (2009); Todd C. Peppers et al., Inside Judicial Chambers: How Federal District Judges Select and Use Their Law Clerks, 71 ALB. L. REV. 623 (2008); Todd C. Peppers \& Christopher Zorn, Law Clerk Influence on Supreme Court Decision Making: An Empirical Assessment, 58 DePAUL L. REV. 51 (2008); David R. Stras, The Supreme Court's Gatekeepers: The Role of Law Clerks in the Certiorari Process, 85 TEX. L. REV. 947 (2007); Rick A. Swanson \& Steven Wasby, Good Stewards: Law Clerk Influence in State High Courts, 29 JuST. SYS. J. 24 (2008); Royce De Rohan Barondes, Want Your Opinions Reversed? Hire a Yale Clerk (and Don't Require the Bar) (Univ. of Missouri-Columbia Sch. of Law Legal Studies Research Grp., Paper No. 2008-8), available at http://papers.ssm.com/sol3/papers.cfm?abstract_id $=1116$ 343.

${ }^{16}$ See 104 CONG. REC. 8107-08 (1957) (remarks of Sen. John Stennis decrying clerks' "ever-increasing importance and influence"); William H. Rehnquist, Who Writes the Decisions of the Supreme Court, U.S. NEWS \& WORLD REP., Dec. 13, 1957, at 74-75 (contending many "liberal" clerks showed "extreme solicitude for the claims of Communists and other criminal defendants, expansion of federal power at the expense of State power, [and] great sympathy toward any government regulation of business," and those biases crept into cert memos).

17 See David Margolick et al., The Path to Florida, VANITY FAIR, Oct. 2004, at 320.

18 See generally EDWARD LAZARUS, ClOSED CHAMBERS (1998); J. HARVIE WILKINSON, III, SERVING JUSTICE (1974); BOB WOODWARD \& SCOTT ARMSTRONG, THE BRETHREN (1979). 
Supreme Court clerks and concluded that clerks are contributing to the Court's ideological polarization. ${ }^{19}$ The authors of that article, along with other scholars, have suggested rotating the clerks among the Justices (or reassigning them to the Court as a whole) to reduce this ideological polarization. ${ }^{20}$ The ideological polarization thesis, which has attracted recent national media attention, ${ }^{21}$ implies that Supreme Court clerks possess too much influence on their Justices.

The emphasis on law clerk influence and ideological polarization is misplaced. Although the role of most clerks has changed from researchers and fact checkers to opinion drafters, ${ }^{22}$ the notion that federal judges delegate too much power to their clerks is overstated. Nearly five years after his clerkship with Justice Robert Jackson and in an article that began the modern debate about law clerk influence, William Rehnquist accurately described clerks as having a "worm's eye view" of the Court. ${ }^{23}$ It is far-fetched to think that during a single year a politically-motivated law clerk can achieve some sort of Svengali power over a much more experienced judge. Judges want clerks who will implement their wishes and that often means hiring likeminded clerks. But just because someone clerked for a Republican-appointed judge does not mean he or she must be a Republican--particularly at the federal courts of appeals, which have more Republican-appointed judges. ${ }^{24}$ Finally, the proposal about rotating clerks among Justices would rob recent

19 William E. Nelson et al., Supreme Court Clerkships Polarization, 13 GREEN BAG 2D 59, 66 (2009) [hereinafter Nelson, Polarization]. But see id. at 62 (disclaiming causal connection between clerkships and ideological polarization).

${ }^{20}$ Id. at 69; Craig S. Lerner \& Nelson Lund, Judicial Duty and the Supreme Court's Cult of Celebrity, 78 GEO. WASH. L. REV. 1255, 1294 (2010) (proposing reassignment of clerks to Supreme Court library); David S. Law, How to Rig the Federal Courts, 99 GEO. L.J. 57 (forthcoming 2011), available at http://papers.ssrn.com/sol3/papers.cfm?abstract id=1578403 (proposing similar arrangement); Stuart Taylor Jr. \& Benjamin Wittes, $\overline{O f}$ Clerks and Perks, ATLANTIC MONTHLY, July/Aug. 2006, at 55 (proposing one clerk per justice and disallowing clerks from drafting opinions).

${ }^{21}$ See Editorial, Politically Charged Clerks, N.Y. Times, Sept. 21, 2010, at A24; Adam Liptak, $A$ Sign of the Court's Polarization: Its Choice of Clerks, N.Y. TimES, Sept. 6, 2010, at A1.

22 See PEPPERS, supra note 15, at 38-205 (defining clerk as "stenographer," "legal assistant," or "law firm associate"); RICHARD A. POSNER, THE FEDERAL COURTS 140-57 (1999) (discussing appellate clerk as "ghostwriter"). Posner is one of few appellate judges who drafts his own opinions.

23 See Rehnquist, supra note 16, at 74 .

${ }^{24}$ See Jason Mazzone, Response to Adam Liptak on the Polarization of Supreme Court Clerks, BALKINIZATION (Sept. 7, 2010, 4:57 PM), http://balkin.blogspot.com/2010/09/response-to-adam-liptak-on-polarization.html (observing that Republican-dominated federal courts of appeals represents change from past eras). 
graduates of the professional rewards from working closely with a single judge.

A better question than the influence of clerks on judges is the influence of judges on clerks. ${ }^{25}$ Influence is difficult to measure because it is not falsifiable and often not quantifiable in large sample sizes. Scholars have attempted to measure judicial influence on clerks through network analyses of pre- and post-clerkship educational and employment connections ${ }^{26}$ and statistical studies of post-clerkship employment of Supreme Court clerks. ${ }^{27}$

Prompted by questions about Friendly's and Rehnquist's influence on Roberts, this Article takes a more humanistic, biographical approach to discern judicial influence on clerks. It explores Roberts's judicial genealogy through detailed primary-source accounts of Brandeis's clerkship with Gray, Friendly's clerkship with Brandeis, and Roberts's clerkships with Friendly and Rehnquist.

By laying the clerkship experiences, career paths, and jurisprudence of Brandeis, Friendly, and Roberts side-by-side, this Article suggests that the influence of judges on clerks is more professional than ideological. Although an admittedly fine line, professional influence includes ethical, jurisprudential, and practical lessons; ideological influence is more political. By the time they start clerkships, most law graduates are fully formed politically or ideologically but inexperienced professionally. Judges play multiple professional roles in the lives of their clerks: as exemplars of judicial ethics, craftsmanship, and decision-making; as mentors and career advisers; and as role models and sources of inspiration long after judges have retired or died.

Gray, Brandeis, and Friendly not only taught their clerks valuable professional lessons but also contributed to the institutionalization of judicial clerkships in American legal culture. Gray, the grandfather of the modern clerkship, pioneered the hiring of recent law graduates for one- or two-year terms as secretaries and sounding boards. Brandeis, inspired by his Gray clerkship and aided by Felix Frankfurter, transformed clerkships into intense, substantive experiences and springboards into government and academia. Friendly perpetuated Brandeis's clerkship model and was one of the first

25 See generally William E. Nelson et al., The Liberal Tradition of the Supreme Court Clerkship: Its Rise, Fall, and Reincarnation?, 62 VAND. L. REV. 1749 (2009) [hereinafter Nelson, Liberal Tradition]; Laura Krugman Ray, Clerk and Justice: The Ties That Bind John Paul Stevens and Wiley B. Rutledge, 41 CONN. L. REV. 211 (2008); Joseph T. Thai, The Law Clerk Who Wrote Rasul v. Bush: John Paul Stevens's Influence from World War II to the War on Terror, 92 VA. L. REV. 501, 526 (2006).

${ }^{26}$ See Daniel Martin Katz and Derek K. Stafford, Hustle and Flow: A Social Network Analysis of the American Federal Judiciary, 71 OHIO ST. L.J. 457 (2010).

27 See generally Nelson, Liberal Tradition, supra note 25. 
modern "feeder" judges; Friendly's former clerks include five current federal appellate judges and the Chief Justice. ${ }^{28}$

As law clerks, Brandeis, Friendly, and Roberts also idealized their judges and exalted the role of the judiciary in American society. The danger of clerkships is not that they promote ideological polarization but that they promote a culture of judicial supremacy. Clerkships have created a class of legal elites who contribute to the professionalization and self-construction of the federal judiciary. Top law graduates vie for clerkships because professors and law firms tell them that clerkships are good training. Peers reinforce that clerkships are prestigious. And for top students, clerkships often perform critical sorting functions that grades and law review cannot. The rewardssix-figure clerkship bonuses, big law firm jobs, teaching opportunities, and government service-are great. Many clerks, if they enjoyed their clerkships, spread the gospel of their judges as wise men or women and the judiciary as a place of intellectual seriousness. But even clerks who did not enjoy their clerkships burnish the reputations of their judges and the judiciary through their post-clerkship accomplishments.

By exploring Brandeis's clerkship with Gray, Friendly's clerkship with Brandeis, and Roberts's clerkships with Friendly and Rehnquist, this Article reveals how judges influence their clerks and how clerks idealize their judges. Roberts's clerkships with Friendly and Rehnquist provide another way of analyzing several of Roberts's high-profile opinions.

Part I examines the origins of the modern clerkship based on Brandeis's clerkship with Gray. Part II explores how Brandeis and Frankfurter transformed the purpose of clerkships and tried to fit Friendly into this mold. Part III reveals how Brandeis influenced Friendly's jurisprudence and how Friendly idealized Brandeis. Part IV explores Roberts's clerkships with Friendly and Rehnquist and his career path to the Supreme Court. Part V explains what Roberts learned from Friendly and Rehnquist and compares Roberts's idealization of Friendly before the Senate Judiciary Committee with several of Roberts's high-profile Supreme Court opinions.

A note on methodology: biographical history, like statistical studies and network analyses, has its methodological limitations. ${ }^{29}$ But, as other scholars have shown, ${ }^{30}$ the power of biographical or narrative history lies in its ability

${ }^{28}$ See infra text accompanying note 383 .

${ }^{29}$ See, e.g., G. EdWard White, The American Judicial Tradition 6 (3d ed. 2007) ("History as biography also overemphasizes individual contributions.").

${ }^{30}$ Id.; Daniel R. Ernst, Willard Hurst and the Administrative State: From Williams to Wisconsin, 18 L. \& HIST. REV. 1, 1, 13 (2000). 
to place someone's career in a broader historical, political, and interpersonal context.

Despite the selection bias of three famous judge-clerk pairs, Brandeis, Friendly, and Roberts's clerkship experiences are historically significant. Legal historians tend to focus on the most prominent legal thinkers or the hardest cases to explore the development of legal liberalism ${ }^{31}$ or the role of public opinion in influencing the Supreme Court and constitutional interpretation. ${ }^{32}$ A judge's professional influence, like that of a great teacher on a prized student, is often most evident in the careers of his or her most successful clerks. Indeed, Friendly's recently processed papers at Harvard Law School provide new insights about Brandeis's influence on Friendly and Friendly's influence on Roberts.

\section{THE GRAY CLERKSHIP: 1875-1902}

The modern judicial clerkship, hiring recent law graduates for one or two years, began in 1875 with Massachusetts Supreme Judicial Court Chief Justice Horace Gray. Gray hired recent Harvard Law School graduates selected by his half-brother, Harvard law professor John Chipman Gray, as legal secretaries. ${ }^{33}$ Gray redefined judicial clerkships in several ways. First, he hired recent graduates for one-year terms rather than career positions. ${ }^{34}$ Second, he relied on a law professor to select his clerks and created a symbiotic relationship between the legal academy and judiciary. ${ }^{35}$ Third, he relied on his clerks for secretarial work such as dictation but also for substantive input on his opinions. ${ }^{36}$ Before Gray, judges hired non-lawyers for stenographic and administrative duties.

31 See generally LaURa KaLMAN, THE STRANGe CAREER OF LEGal LiberalisM (1996).

32 See generally BARRy Friedman, The Will of the PEOPle (2009).

33 PePpers, supra note 15, at 43-48, 51-52; Todd C. Peppers, Birth of an Institution: Horace Gray and the Lost Law Clerks, 32 J. SUP. CT. HIST. 229, 231 (2007) [hereinafter Peppers, Birth of an Institution].

${ }^{34}$ See Recollections of Mr. [Langdon Parker] Marvin on Presentation of Brandeis's Bust to Harvard Law School (on file with Felix Frankfurter Papers [hereinafter FF-LC], Library of Congress, Box 127, Folder "Brandeis, Louis D. 1939-59," at 3) (recalling Gray's secretaries as "annuals" because of one-year stay).

35 Peppers, Birth of an Institution, supra note 33, at 238 (detailing how three former Gray clerks taught at Harvard Law School and another at Northwestern University and the University of Chicago).

${ }^{36}$ See id. at 232-33 (explaining clerkship duties and remarking, "Gray treated his young assistants as more than mere scriveners"); infra text accompanying note 42 (Brandeis's account of his clerkship duties). 
Gray brought his innovative clerkship to the U.S. Supreme Court from 1891 to 1902 and remained ahead of his time. ${ }^{37}$ Upon Gray's death in 1903, only his successor on both courts, Oliver Wendell Holmes Jr., had adopted his clerkship model. The next clerkship innovator was one of Gray's former clerks, Louis Brandeis.

\section{A. Brandeis's Background}

Gray hired Brandeis because of his academic reputation-Brandeis had enrolled at Harvard Law School at age eighteen without an undergraduate degree (he had studied for two years in Dresden, Germany) and graduated two years later with the "highest known" record in the law school's history, a 97 out of 100 based on the grading scale at the time. ${ }^{38}$ After a year of postgraduate study at the law school, Brandeis moved to St. Louis to be near his sister and brother-in-law but left after seven unhappy months for Boston. ${ }^{39}$

The Gray clerkship gave Brandeis the opportunity to earn some money and gain inroads into the Boston legal community. Torn between private practice and teaching at Harvard Law School, Brandeis decided to start a law firm with Harvard classmate Samuel Warren. The clerkship satisfied his

${ }^{37}$ Before 1919, Supreme Court justices (and lower court judges) hired law clerks through federal funding for stenographers. In 1919 , Congress provided $\$ 2,000$ for a stenographic clerk and $\$ 3,600$ for a law clerk. PEPPERS, supra note 15 , at 83 .

38 James Landis, Mr. Justice Brandeis and the Harvard Law School, 55 HARV. L. REV. 184, 184 (1941). But see Garfield Horn, Landis Research Assistant, Original Draft of Mr. Justice Brandeis and the Harvard Law School 1 n.2 (Oct. 28, 1941) (on file with James Landis Papers [hereinafter Landis Papers], Library of Congress, Box 169, Folder "Mr. Justice Brandeis and the Harvard Law School, Harvard Law Review 1941") (explaining that "[h]is average for the two-year course of those days was 97 (but it should be remembered that the marking system at that time differed to some extent from what it now is, so that grades of 90 or better, while exceptional, were not extraordinary)" and noting that, "[s]ubsumed in this [mark of] 97 were three marks of 100 and two of 99") (emphasis added) (based on "Law School records, Secretary's Office, Gannett House"); ARTHUR E. SUTHERLAND, THE LAW AT HARVARD: A HISTORY OF IDEAS AND MEN, 18171967 , at $198 \mathrm{n} .44$ (1967) (explaining that "[t]radition gives to Justice Brandeis the highest grades ever attained at the Harvard Law School. Notation of excellence on a scale of 100 has varied over the years, so that a grade of 90 -odd in 1878 is not convertible into the same figures in 1967;" nonetheless, "the astonishingly high quality of Brandeis'[s] work is still entirely evident"); cf. Secretary to Justice Brandeis Nearly Ties His Harvard Rank, ChRISTIAN SCI. MONITOR, Sept. 12, 1927, at 1 [hereinafter Secretary Nearly Ties Rank] (acknowledging changing scale but claiming Brandeis averaged 87 out of 100); infra note 106.

39 MELVIN I. UROFSKY, LOUIS D. BRANDEIS: A LIFE 32-45 (2009). 
brother-in-law Charles Nagel and his Harvard professors. ${ }^{40}$ In July 1879, Brandeis wrote Harvard classmate Walter Bond Douglas:

I have accepted a position with Ch. Justice Gray as his Secty \& Assistant which gives me a salary about $\$ 500$ - does not take very much of my time, will be very instructive and is deemed by Bradley[,] Thayer \& Langdell very valuable as a stepping stone. Most of the work for the C.J. falls in summer so that it will not greatly interfere with the practice. ${ }^{41}$

In fact, Brandeis clerked and practiced law at the same time.

\section{B. Brandeis's Clerkship Experience}

From the first week of his clerkship, Brandeis idealized and mythologized Gray to friends and family. Brandeis wrote Nagel:

My position with the Ch.J is pleasanter than my fondest hopes had pictured. None of the unpleasant peculiarities for which Judge Gray is noted have appeared in my intercourse with him. His arrogance and impatience are apparently the judicial wig \& gown, for off the bench, there is no sign of them. On the contrary, he is the most affable of men, patiently listening to suggestions and objections \& even contradiction. I have worked with him daily since Tuesday and have enjoyed most of the mornings keenly. Our mode of working is this. He takes out the record \& briefs in any case, we read them over, talk about the points raised, examine the authorities' arguments-then he makes up his mind if he can, marks out the line of argument for his opinion, writes it, \& then dictates it to me.

But I am treated in every respect as a person of co-ordinate position. He asks me what I think of his line of argument and I answer candidly. If I think other reasons better, I give them; if I think his language is obscure, I tell him so; if I have any doubts I express them and he is very fair in acknowledging a correct suggestion or disabusing one of an erroneous idea.

In these discussions \& investigations I shall learn very much. Many beautiful points are raised and must be decided. The $\mathrm{Ch}$. Justice has a

40 Alpheus Thomas Mason, Brandeis: A Free MaN's Life 57 (1946) (quoting letter from Charles Nagel to Louis D. Brandeis (July 5, 1879), describing Gray clerkship as the "most desirable of all the chances offered you in Boston"); infra text accompanying note 44 .

${ }^{41}$ Letter from Louis D. Brandeis to Walter Bond Douglas (July 6, 1879), reprinted in 1 LETTERS OF LOUIS D. BRANDEIS, 1870-1907, at 36 (Melvin I. Urofsky \& David W. Levy eds., 1971) [hereinafter 1 LETTERS OF LDB]. 
marvellous [sic] knowledge of Mass. decision[s] \& Statutes and I expect much advantage in this respect. ${ }^{42}$

Brandeis's only ministerial task was taking dictation, but he had not done any the first week. ${ }^{43}$ Brandeis worked for Gray from 9 a.m.-2 p.m., then spent the rest of the day building his practice with Warren. ${ }^{44}$ After the first month, Brandeis wrote his brother that the clerkship "is as pleasant and interesting as ever." 45 Thanks to Gray, Brandeis was admitted to the Massachusetts bar without taking the exam. ${ }^{46}$ Gray praised Brandeis's work and sent him clients. ${ }^{47}$ Brandeis clerked for nearly two terms until Gray left for the U.S. Supreme Court.

Upon Gray's departure, Brandeis wrote the new Supreme Court Justice a fawning letter:

When Ximenez was made Archbishop of Toledo a brother prelate wrote to him: "For Your Reverence I am happy, but for myself most sorry; for I fear I have lost a good friend."

Such apprehensions do not disturb me; but I deeply regret the prospect of losing so good a [Mass.] Chief Justice. ${ }^{48}$

Brandeis clerked for Gray for the money, because Brandeis's Harvard professors encouraged him to do it, and because Brandeis needed contacts in the Boston legal community to build his law practice. Brandeis did not clerk for Gray because of the position's prestige or status. The Gray clerkship did not put Brandeis in a nationally recognized class of legal elites. Nor was

42 Letter from Louis D. Brandeis to Charles Nagel (July 12, 1879), reprinted in 1 LETTERS OF LDB, supra note 41 , at 38, and THE FAMILY LETTERS OF LOUIS D. BRANDEIS at 16-17 (Melvin I. Urofsky \& David W. Levy eds., 2002) [hereinafter FAMILY LETTERS].

43 See id.

44 Letter from Louis D. Brandeis to Frederika Dembitz Brandeis (July 20, 1879), reprinted in FAMILY LETTERS, supra note 42, at 20-21, and MASON, supra note 40, at 60 ("Because I have little or no work at all to do for the C.J., I shall devote myself this week to our own affairs, try to collect some debts for a client and probably examine a title for a lot.").

45 See Letter from Louis D. Brandeis to Alfred Brandeis (July 31, 1879), reprinted in FAMILY LETTERS, supra note 42, at 22.

${ }^{46}$ Letter from Brandeis to Nagel (July 12, 1879), supra note 42 , reprinted in FAMILY LETTERS, supra note 42, at 17, 19 n.5.

${ }^{47}$ Letter from Louis D. Brandeis to Alfred Brandeis (July 30, 1881), reprinted in 1 LETTERS OF LDB, supra note 41, at 63-64; UROFSKY, supra note 39, at 52.

${ }^{48}$ Letter from Louis D. Brandeis to Horace Gray (Dec. 20, 1881) (on file with FFLC, supra note 34, Box 127, Folder "Brandeis, Louis D. 1939-59"). 
Brandeis identified as a former Gray clerk. Clerkships were in their infancy and not considered plum credentials. Clerking for Gray taught Brandeis about judicial decision-making and craftsmanship and the need to address arguments on both sides of an issue. Most of all, however, Gray influenced Brandeis by providing him the model for the modern judicial clerkship.

\section{THE BRANDEIS CLERKSHIP: 1916-1939}

The first former-clerk-turned-federal-judge when Wilson nominated him to the Supreme Court in 1916, Brandeis adopted aspects of Gray's clerkship model and transformed clerkships as a legal and cultural institution. If Gray initiated the modern clerkship and Holmes copied it, then Brandeis perfected it. Gray employed his clerks as secretaries who still acted as stenographers yet contributed some substantive suggestions. The childless Holmes employed clerks/secretaries. He sought well-read companions to walk (and later take drives) with him, listen to his Civil War stories, read and discuss literature, and serve as his surrogate sons. ${ }^{49}$ Holmes's clerks read certiorari petitions and commented on his draft opinions; they also paid his bills, balanced his checkbook, responded to fan mail, and in later years read books to him. ${ }^{50}$ Though he still referred to them as secretaries, Brandeis turned his

${ }^{49}$ FranCiS BIDdLe, Mr. JUSTICE HolmES 12 (1942) ("Gray knew the kind of boys Holmes wanted-they must be able to deal with the certiorari, balance his checkbook, and listen to his tall talk."); see id. at 82-83, 148-49; THE MAKING OF THE NEW DEAL 2346 (Katie Louchheim ed., 1983) (containing recollections of Holmes clerks Thomas Corcoran, Alger and Donald Hiss, and James Rowe); I. Scott Messinger, The Judge As Mentor: Oliver Wendell Holmes, Jr. and His Law Clerks, 11 YALE J.L. \& HuMAN. 119, 120 (1999) (discussing Holmes's mentoring of his clerks and his clerks' "veneration" of Holmes); Mark DeWolfe Howe, Mr. Justice Holmes and His Secretaries, N.Y. TIMES MAG., Apr. 8, 1951, at 15, 42 (describing duties "of the most trivial significance" but learning about work ethic that Holmes described as his "jobbist" philosophy).

In 1912, President Taft's son, Robert, declined a clerkship with Holmes in favor of private practice in Cincinnati. See Letter from Robert Taft to William H. Taft 2 (Nov. 13, 1912) (on file with William H. Taft Papers [hereinafter WHT-LC], Library of Congress, reel 452, image 174) (desiring to start practice in Cincinnati rather than accepting Holmes's offer); Letter from William H. Taft to John Gray (Nov. 19, 1912) (on file with WHT-LC, supra, reel 452, image 176) ("[W] hat [Robert] needs more than anything else is experience in the actual drudgery of the practice and procedure in Ohio."); Letter from William H. Taft to Robert Taft (Nov. 19, 1912) (on file with WHT-LC, supra, reel 452, image 177) ("That need [to practice in Ohio] is much more preemptory than the need of anything that you would derive through an association, as a secretary, with Mr. Justice Holmes."). Young Taft's decision reveals the status of clerkships in 1912 and Frankfurter's subsequent elevation of clerkships into highly sought-after prizes.

50 Biddle, supra note 49, at 12; JoHN S. MONAGAN, THE GRAND PANJANDRUM: Mellow Years of Justice Holmes 114 (1988) (describing these "largely secretarial" duties of Holmes clerks); THE MAKING OF THE NEW DEAL, supra note 49, at 23-33. 
clerks into law firm associates - to research case law, legislative histories, and economic or sociological studies at the Library of Congress; check facts; criticize his opinions; and serve as his "disciples." 51

Brandeis could not have perfected his clerkship model without assistance from a young Harvard professor, Felix Frankfurter. Frankfurter, like Brandeis, viewed public service as a higher calling. An Anglophile inspired by the British civil service, Frankfurter believed that the federal government's corruption and incompetence could be reduced with an expert class of lawyers turned public servants. ${ }^{52}$ Frankfurter found his future experts at Harvard Law School, molded them during post-graduate research fellowships, and selected them to clerk for Brandeis, Holmes, and lower court judges. After their clerkships, many - such as Dean Acheson, Tommy Corcoran, and James Landis-joined the Roosevelt administration and helped implement the New Deal. ${ }^{53}$ Through clerkships, Frankfurter created an "old boy network" and class of legal elites primed for public service and transformed clerkships into an insular path to power. ${ }^{54}$ Karl Llewellyn wrote: "I should be inclined to rate it as Frankfurter's greatest contribution to our law that his vision, energy, and persuasiveness turned this two-judge

51 See Todd C. Peppers, Isaiah and His Young Disciples: Justice Brandeis and His Law Clerks, 34 J. SUP. CT. HIST. 75, 75 (2009) [hereinafter Peppers, Isaiah and His Young Disciples] (crediting Brandeis with "professionalization of the clerkship institution"); Nelson, Liberal Tradition, supra note 25, at 1769 (describing Brandeis's goal of turning clerks into law professors "engag[ing] in scholarly projects such as critiquing, explaining, and justifying the work of the Court, or generating historical and social science information for the Justices. This vision endured for some three-quarters of a century after Brandeis's ascension to the bench."); see also STEPHEN W. BASKERVILLE, OF LAWS AND LIMITATIONS: AN INTELLECTUAL PORTRAIT OF LOUIS DEMBITZ BRANDEIS 235-39, 279-90 (1994); PHILIPPA STRUM, LOUIS D. BRANDEIS: JUSTICE FOR THE PEOPLE 355-71 (1984); LEWIS J. PAPER, BRANDEIS 244-46 (1983); UROFSKY, supra note 39, at 464-78.

52 Felix Frankfurter, The Public \& Its Government 113-14, 144-45, 157-58 (1930); Ernst, supra note 30, at 13.

53 Felix Frankfurter, The Young Men Go to Washington, FoRTUNE, Jan. 1936, at 61, reprinted in FELIX FRANKFURTER, LAW AND POLITICS 238-49 (Archibald MacLeish \& E.F. Prichard, Jr. eds., 1939).

54 G. Edward White, Felix Frankfurter, the Old Boy Network, and the New Deal: The Placement of Elite Lawyers in Public Service in the 1930s, 39 ARK. L. REV. 631, 654-59 (1986). This old boy network, of course, excluded blacks and women (Harvard admitted few of the former and none of the latter during the 1920s and 1930s). William O. Douglas hired Lucile Lomen, the first female Supreme Court clerk, in 1944, and thenJustice Frankfurter hired William T. Coleman, the first black Supreme Court clerk, in 1948. David J. Danelski, Lucile Lomen: The First Woman to Clerk at the Supreme Court, 23 J. SUP. CT. Hist. 43, 43 (1999); Todd C. Peppers, William Thaddeus Coleman, Jr.: Breaking the Color Barrier at the U.S. Supreme Court, 33 J. SUP. CT. HIST. 353, 353 (2008). 
idiosyncrasy [Gray and Holmes's clerkship model] into what shows high possibility of becoming a pervasive American institution."55

Like Holmes, Brandeis relied on Frankfurter to select his clerks and rejected at least one pre-clerkship interview request. ${ }^{56}$ By the 1930s, Frankfurter was choosing clerks for five and sometimes six judges.57 Brandeis's criteria differed from the others; he preferred Jews and future law professors. ${ }^{58}$ Brandeis believed that Jews, excluded from law firms because of their religion, should teach:

It seems to me that a great service could be done generally to American law and to the Jews by placing desirable ones in the law school faculties. There is in the Jew a certain potential spirituality and sense of public service which can be more easily aroused and directed, than at present is discernible in American non-Jews. And the difficulty which the Law Schools now have

55 Karl N. Llewellyn, The Common law Tradition: Deciding appeals 321 $(1960)$.

56 Interview by Lewis Paper with Adrian S. Fisher, in Washington, D.C. 1 (Aug. 11, 1980) (on file with Lewis J. Paper Papers [hereinafter Paper Papers], Harvard Law School Special Collections Library, Box 1, Folder 1-3 "Paper Ints. pt. I") ("I asked if I could meet the Justice before, just to make sure he didn't think he was getting a pig in the poke or anything, but Felix looked at me like that was a real strange request, and so I never met Brandeis before my clerkship began."); $c f$. Interview by Lewis Paper with David Riesman 1 (May 5, 1981) (on file with Paper Papers, supra, Box 1, Folder 1-4 "Paper Ints. pt. II") (describing meeting Brandeis, Cardozo, and Holmes after second year of law school, but Frankfurter rejected request to clerk for Cardozo). Riesman's preclerkship meeting was the exception rather than the rule. See infra text accompanying notes 123-25 (describing Friendly's unusual pre-clerkship meeting).

${ }^{57}$ Besides Holmes and Brandeis, Frankfurter selected clerks for Augustus Hand, Learned Hand, Julian Mack, and "triennially" for then-New York Court of Appeals Judge Benjamin Cardozo. Letter from Felix Frankfurter to Learned Hand (Dec. 20, 1934) (on file with Learned Hand Papers [hereinafter Hand Papers], Harvard Law School, Box 105A, Folder 105-2) (explaining his selection process for six judges); see also Letter from Felix Frankfurter to Harold Stephens (Sept. 10, 1935) (on file with Harold Stephens Papers, Library of Congress, Box 14) (claiming to have "had the designation of five men for five federal judges"); GERALD GUNTHER, LEARNED HAND: THE MAN AND THE JUDGE 289 (1994) (selecting Hand clerks from 1930 to 1939); ANDREW L. KAUFMAN, CARDOZO 474 (1998) (selecting Cardozo's New York Court of Appeals clerks every third year and his first and last Supreme Court clerks, Melvin Siegel and Joseph Rauh).

${ }^{58}$ Letter from Louis D. Brandeis to Felix Frankfurter (Oct. 13, 1929) (on file with FF-LC, supra note 34, Box 28, Folder "Brandeis, Louis D. 1929 \#44"), reprinted in 5 LeTTERS OF LoUIS D. BRANDEIs, 1921-1941, at 404 (Melvin I. Urovsky \& David W. Levy eds., 1978) [hereinafter 5 LETTERS OF LDB]; Letter from Louis D. Brandeis to Felix Frankfurter (Jan. 28, 1928) (on file with FF-LC, supra note 34, Box 27, Folder "Brandeis, Louis D. \#36"), reprinted in 5 LETTERS OF LDB, supra, at 319-20. 
in getting able men may offer opportunities, not open in other fields of intellectual activity. 59

Brandeis viewed law schools as ripe for his progressive ideas and law teaching as the highest form of public service. His former clerks could produce a ripple effect by spreading progressive, public-service-oriented ideas to generations of America's future lawyers, businessmen, and political leaders. Of Brandeis's twenty-one clerks, nine were Jews and eleven went on to teach. ${ }^{60}$ At one point, Brandeis counted his former clerks in academia and declared: "Now I have a majority."61 Upon his eightieth birthday, Brandeis's clerks proposed a reunion; Brandeis preferred "a message from each of the group recounting the public service that he had of late been performing." 62

Brandeis wanted unmarried and hard-working clerks because his clerkship was exhausting. ${ }^{63}$ His clerks usually lived in the same Washington, D.C., apartment building as he and his wife, worked during the day out of a second downstairs apartment that served as the Justice's office, served guests at the Justice's late Monday afternoon teas, and made guests leave his dinner parties by his 10 p.m. bedtime. ${ }^{64}$ Brandeis arose at 5 a.m., worked all day, but never at night; his clerks worked all day and at night to keep up with him. They often awoke to notes under their door that said: "Please see me when you come in. L.D.B." 65 Brandeis, unlike Holmes, was obsessed with facts

${ }^{59}$ Letter from Brandeis to Frankfurter (Oct. 13, 1929), supra note 58, at 404.

${ }^{60}$ David Riesman started at University of Buffalo Law School before joining Harvard's sociology department. Calvert Magruder, Brandeis's first clerk, taught at Harvard Law School before his First Circuit nomination. See MASON, supra note 40, at 690; STRUM, supra note 51, at 359; Nelson, Liberal Tradition, supra note 25, at 1758-59; Peppers, Isaiah and His Young Disciples, supra note 51, at 90.

${ }^{61}$ Francis Biddle, The Friendship of Holmes and Brandeis, THE ATLANTIC MONTHLY, Dec. 1965, at 89 (citing Paul Freund).

62 Paul A. Freund, Mr. Justice Brandeis, 55 HARv. L. Rev. 181, 195 (1941); see also Paul A. Freund, An Appreciation of Mr. Justice Brandeis, 11 ST. LoUIS U. L.J. 1, 4 (1966).

${ }^{63}$ Letter from Louis D. Brandeis to Felix Frankfurter (Oct. 23, 1922) (on file with FF-LC, supra note 34, Box 26, Folder "Brandeis, Louis D. 1922 \#15") ("I shall leave your discretion to act untrammeled. Wealth, ancestry, and marriage, of course, create presumptions; but they may be overcome.").

64 See Interview with James Landis, Oral History Project, Columbia University (1963-64) 67-68, 70 [hereinafter Landis COH]; Paul A. Freund, Justice Brandeis: A Law Clerk's Remembrance, 68 AM. JEWISH HIST. SOC'Y 7, 8-9 (1978) [hereinafter Freund, $A$ Law Clerk's Remembrance].

65 Paul A. Freund, Mr. Justice Brandeis: A Centennial Memoir, 70 HARV. L. REV. 769, 775 (1957) [hereinafter Freund, Centennial Memoir]; Landis COH, supra note 64, at 65-67. 
and revolutionized the law with his sociological jurisprudence. ${ }^{66}$ Brandeis sent clerks to the Library of Congress for scientific studies, statistics, or forty-eight state legal surveys for use in footnotes. Clerks checked all facts in Brandeis's opinions against the legal record and all case citations. They suggested substantive changes to his opinions, but Brandeis always wrote the first draft in his own hand and obsessively revised multiple drafts. He used the Court's print shop as his typist, sent many drafts to the printer, and requested two copies: one for him and one for his clerk. ${ }^{67}$ Because his clerks served only as researchers, fact-checkers, and critics, Brandeis remarked: "The reason the public thinks so much of the Justices of the Supreme Court is that they are almost the only people in Washington who do their own work." 68

Brandeis was a tough taskmaster. He expected his clerks to perform at a high level, never complimented them when they performed well, and complained to Frankfurter or the clerks when they performed poorly. Dean Acheson clerked for two terms in part because his first was so mediocre. After Acheson apologized for including two irrelevant cases in an almostpublished footnote, Brandeis said: "Please remember that your function is to correct my errors, not to introduce errors of your own." 69 Other clerks received similar lectures. ${ }^{70}$ They received positive feedback only from Frankfurter or Mrs. Brandeis. ${ }^{71}$ During the clerkship, Brandeis taught by example. He did not befriend his clerks until after their clerkships were over.

66 See Letter from Justice Oliver Holmes to Frederick Pollock (May 26, 1919), reprinted in 2 HOLMES-POLLOCK LETTERS: THE CORRESPONDENCE OF MR. JUSTICE HOLMES AND SIR FREDERICK POLLOCK 1874-1932, at 13 (Mark DeWolfe Howe ed., 1946).

${ }^{67}$ Freund, Centennial Memoir, supra note 65, at 776; Charles E. Wyzanski, Jr., Brandeis: An Atlantic Portrait, The ATLANTIC MONTHLY, Nov. 1956, at 67.

68 Wyzanski, supra note 67 , at 71 .

69 DEAN ACHESON, MORNING AND NoON 80 (1965).

70 James M. Landis, Mr. Justice Brandeis: A Law Clerk's View, 46 AM. JEWISH HIST. SOC'Y 467, 468 (1957) (“'Sonny, we are in this together. You must never assume that I know everything or that I am even correct in what I may say. That is why you are here. Don't let's have it happen again."'); see also Letter from James M. Landis to Felix Frankfurter 1-2 (Nov. 1, 1925) (on file with FF-LC, supra note 34, Box 74, Folder "Landis, James M. 1925-39 \& undated") (recounting mistake); Letter from Paul A. Freund to Felix Frankfurter (Nov. 15, 1932) (on file with FF-LC, supra note 34, Box 56, Folder "Freund, Paul A. 1932-42"); Interview by William A. Sutherland with Lewis Paper, in Washington, D.C. 2 (Nov. 7, 1980) [hereinafter Paper-Sutherland Interview] (on file with Paper Papers, supra note 56, Box 1, Folder 1-4 "Paper Ints. pt. II").

${ }^{71}$ Nathaniel L. Nathanson, Mr. Justice Brandeis: A Law Clerk's Recollections of the October Term, 1934, 15 AM. JEWISH ARCHIVES 6, 12 (1963); see, e.g., Letter from Felix Frankfurter to Willard Hurst (Oct. 22, 1936) (on file with Felix Frankfurter Papers, Harvard Law School [hereinafter FF-HLS], pt. III, reel 39, at 691). 
After their clerkships, most Brandeis clerks burnished his reputation in memoirs, articles, and oral histories. Selecting clerks to create a class of elite public servants and scholars, Brandeis contributed to the self-construction of the federal judiciary and his own canonization. Through clerkships, Brandeis and Frankfurter strengthened the symbiotic relationship between law professors and judges. Attracting top students like Friendly was essential if clerkships were to become an elite credential and a training ground for academia and public service. If not for Frankfurter's mentoring, Friendly might not have attended Harvard Law School, much less succeeded Brandeis as the school's academic star.

\section{A. The Courtship of Henry Friendly}

\section{Background}

Born in Elmira, New York, on July 3, 1903, Henry Jacob Friendly was the only child of a loving mother and harsh father who presided over the Friendly Boot Company, a wholesale boot and shoe business. ${ }^{72}$ Myer and Leah Friendly were second-generation German Jews, not very religious, and upper-middle class-much like Brandeis's first-generation parents before they had fallen on harder times. The Friendlys employed two servants, vacationed in Europe, and retired to Florida in their fifties. ${ }^{73}$ At age sixteen, Henry graduated as class valedictorian, school newspaper editor, and top debater from the public Elmira Free Academy ${ }^{74}$ and enrolled at Harvard College "with the intention of going on to "the Law School." 75

An undergraduate history major, Friendly nearly abandoned his law school plan after a senior year British history course with Charles $\mathrm{H}$.

72 Interviews by Ellen Robinson Epstein \& David Epstein, Center for Oral History, with Henry J. Friendly, in Ellen Robinson Epstein \& David Epstein, Henry J. Friendly: An Oral History (1974) [hereinafter Friendly-Epsteins Interview] pt. I, side 1, at 5-6 (describing father as "stern" and mother as "very soft, loving"); Tom Byrne, Old Home Day, Elmira Sun. Tel., Sept. 20, 1970, at 9A (on file with Henry Friendly Papers [hereinafter Friendly Papers], Harvard Law School, Special Collections Library, Box 235, Folder 95-3 "Scrapbook 1959-present").

${ }^{73}$ Friendly-Epsteins Interview, supra note 72, pt. I, side 1, at 7 (father's retirement at age fifty-five); pt. I, side $1, i d$. at 9 (describing family as "always comfortable. Not rich, but we didn't want for anything"); id. pt. I, side 1, at 12 (attending reform synagogue); $i d$. at 35 , pt. II, side 1 (celebrating Christmas "in a mild way"); $i d$. pt. II, side 1, at 36 (two maids plus a handyman); Bureau of Census, U.S. Dep't of Commerce, Fifteenth Census of the United States: 1930, St. Petersburg, Pinellas, Florida, Roll 329, at 34, Enumeration District: 1, Image 7.0.

${ }^{74}$ Byrne, supra note 72 , at $9 \mathrm{~A}$.

${ }^{75}$ Henry J. Friendly, Mr. Justice Frankfurter, 51 U. VA. L. REV. 552, 552 (1965). 
Mcllwain. ${ }^{76}$ Mcllwain piqued Friendly's interest in English legal historian Frederic Maitland ${ }^{77}$ and taught Friendly to "[n]ever [t]rust [a] [s]econdary [s]ource"78 and that "one must read words as they meant to people of the times rather than as they mean to us." ${ }^{79}$ McIlwain assigned a book in Latin without mentioning a Latin prerequisite. ${ }^{80}$ Despite rudimentary knowledge of Latin, Friendly performed so well that Mcllwain encouraged him to get his $\mathrm{Ph} . \mathrm{D}$. in medieval history with an implicit promise of a Harvard professorship. ${ }^{81}$ Friendly's paper for Mcllwain's class, "Church and State in England under William The Conqueror," won the $\$ 250$ Bowdoin Prize for the best essay in the English language. Harvard awarded him a year-long fellowship to study medieval legal history in Paris and Oxford. ${ }^{82}$

Friendly's intention to pursue a history Ph.D. alarmed his parents, who saw their son's legal career in jeopardy. ${ }^{83}$ Friendly's mother sought advice

${ }^{76}$ Id.; Friendly-Epsteins Interview, supra note 72, pt. III, side 1, at 8-9 ("came very near to changing my life"); Unveiling of the Bust of Honorable Henry J. Friendly [hereinafter Friendly Unveiling], 887 F.2d XCII, XCVII (1989) (remarks of Paul Freund); Paul A. Freund, In Memoriam: Henry J. Friendly, 99 HARV. L. REv. 1715, 1715-16 (1986) [hereinafter Freund, In Memoriam].

${ }^{77}$ Letter from Charles H. McIlwain to Henry J. Friendly (Mar. 7, 1959) (on file with Friendly Papers, supra note 72, Box 235, Folder "Scrapbook 1954-1959"); Letter from Henry J. Friendly to Charles H. McIlwain (Mar. 21, 1959) (on file with Friendly Papers, supra note 72, Box 191, Folder 191-13); Letter from Henry J. Friendly to Charles E. Wyzanski (Feb. 6. 1986) (on file with Friendly Papers, supra note 72, Box 221, Folder 221-3); Letter from Henry J. Friendly to Paul Buck 2 (Aug. 15, 1974) (on file with Friendly Papers, supra note 72, Box 219, Folder 219-3) ("McIlwain was as great a teacher as I ever had and I include in this my wonderful teachers at the Harvard Law School-Williston, Scott, Frankfurter, T.R. Powell, and others."); Letter from Henry J. Friendly to John G. Buchanan 1-2 (July 17, 1968) (on file with Friendly Papers, supra note 72, Box 217, Folder 217-6).

78 Friendly-Epsteins Interview, supra note 72, pt. II, side 1, at 57.

79 See Letter from Friendly to Buck (Aug. 15, 1974), supra note 77, at 2.

80 See Letter from Friendly to Buchanan (July 17, 1968), supra note 77, at 1.

81 Freund, In Memoriam, supra note 76, at 1715 (claiming Friendly received "virtual assurance from Professor Frederick Merk that he would be appointed in due course to the faculty"). Merk adjudged one of Friendly's examination answers "worthy of publication in a professional journal," $i d$. at 1716 , but Merk would have been very junior to promise to hire Friendly. See John Morton Blum, A Celebration of Frederick Merk (1887-1977), 54 VA. QTRLY. REV. 446, 446-53 (1978) (describing Merk beginning in 1921 as instructor who assisted Mcllwain with courses).

${ }^{82}$ Harvard Awards Prizes, N.Y. TIMES, June 9, 1923, at 10; University Awards 15 Literary Prizes, HARV. CRIMSON, June 9, 1923; see also Announcement Made of Bowdoin Prize Winners in Three Competitions, HARV. CRIMSON, June 20, 1922 (announcing Friendly's essay, "The Fall of Naples: An Episode in the Risorgimento," won second prize).

${ }^{83}$ Friendly-Epsteins Interview, supra note 72, pt. III, side 1, at 9. 
from Julian Mack, a Jewish federal judge whom she had met in Chicago. ${ }^{84}$ Judge Mack encouraged Friendly to contact Frankfurter, the law school's forty-one-year-old wünderkind and fellow secular Jew. ${ }^{85}$

The effusive and effervescent Frankfurter and modest and shy Friendly were complete opposites.86 "Frankfurter was all charisma," former Frankfurter clerk Andrew Kaufman recalled. "Friendly had none." 87 Friendly was not interested in the lives of others, but in the life of the mind. Yet, Friendly recalled of Frankfurter: "He was the most stimulating and likeable person I ever met." 88

During their first meeting over lunch at the Brattle Inn, ${ }^{89}$ Frankfurter radiated enthusiasm and described Harvard Law School as a place of intellectual energy. ${ }^{90}$ He knew not to tell an accomplished Harvard senior what to do. Instead, he encouraged Friendly to study "medieval history, or civil law, or nothing at all" during his fellowship, then give Harvard Law School a one-year tryout. ${ }^{91}$ If law school did not suit him, Friendly could return to medieval history. Friendly, who turned twenty after graduation, agreed. ${ }^{92}$

\section{Harvard Law School}

On the first day of law school, Friendly's confidence and reputation soared. His torts professor, Manley Hudson, asked whether a judicial opinion was the "original text." ${ }^{" 93}$ Friendly said no. ${ }^{94}$ When Hudson produced the original text, Friendly identified it as Norman or Old French and translated it for the class. ${ }^{95}$ "So that really made my reputation at the Harvard Law

${ }^{84}$ Id.; id. pt. VI, side 2, at 2.

${ }^{85}$ Id. pt. III, side 1, at 9; Interview by Lewis Paper with Henry J. Friendly, in New York City, N.Y. 1 (Dec. 27, 1980) (on file with Paper Papers, supra note 58, Box 1, Folder 1-3 "Paper Ints. Part I") [hereinafter Paper-Friendly Interview].

${ }^{86}$ Friendly-Epsteins Interview, supra note 72, pt. III, side 1, at 3 (admitting lack of friends as Harvard freshman because "I of course was a boy from the country, and I was rather shy").

${ }^{87}$ Interview with Andrew Kaufman, Professor, Harvard Law School, in Cambridge, Mass. (June 24, 2009).

88 Paper-Friendly Interview, supra note 85 , at 1.

${ }^{89}$ Letter from Henry J. Friendly to Felix Frankfurter (Feb. 23, 1957) (on file with FF-LC, supra note 34, Box 56, Folder "Friendly, Henry J. 1956-58 \#3").

${ }^{90}$ Friendly, Mr. Justice Frankfurter, supra note 75, at 552 ("electric current").

${ }^{91}$ Id.; Paper-Friendly Interview, supra note 85, at 1.

92 Paper-Friendly Interview, supra note 85 , at 1.

93 Friendly-Epsteins Interview, supra note 72, pt. V, side 1, at 5-6.

94 Id.

$95 \mathrm{Id}$ 
School, on the first day," he recalled. ${ }^{96}$ Friendly later learned that Frankfurter had orchestrated his colleague's questions. ${ }^{97}$ Friendly's performance was no fluke. Professor Thomas Reed Powell described Friendly as a "highly unrewarding student" in constitutional law because after Friendly answered a question, Powell's only response was: "The next case is . . ."98 That first year, Frankfurter "made sure I enjoyed it," Friendly recalled. "I can still see him bounding down the steps of Langdell [Hall] to meet me for lunch. And every few weeks he would invite me over to his house for dinner. The result was I stayed."99

For Friendly, Harvard Law School proved "terribly disappoint[ing]."100 "After a few thrilling months with Williston and Hudson at the beginning of the first year, everything seemed to slide[,]" Friendly wrote Frankfurter after graduation. 101 Friendly lambasted the "method of instruction" as not producing classroom discussion, "[aside from] Williston and Hudson in the first year, and [Frankfurter] and Joe Warren and occasionally Powell in the third"; his fellow top students, six "magna cum laudes" whose intellectual capabilities he critiqued; and the law school as a whole, which he labeled "pretty bad."102 Friendly acknowledged that "I am a person with a grudge. And like most persons with grudges I wonder whether it was always so."103 Friendly second-guessed his choice of law over history for much of his life. ${ }^{104}$

96 Id.; Secretary Nearly Ties Rank, supra note 38, at 1.

${ }^{97}$ Friendly-Epsteins Interview, supra note 72, pt. V, side 1, at 5-6.

98 Friendly Unveiling, 887 F.2d at XCVII (remarks of Paul Freund).

99 Paper-Friendly Interview, supra note 85, at 1; Friendly-Epsteins Interview, supra note 72, pt. III, side 1, at 9; id. pt. IV, side 2, at 4; Henry J. Friendly, Book Review, 31 BROOK. L. REV. 442, 442-43 (1964) (reviewing PERSPECTIVES ON LAW: ESSAYS FOR AUSTIN WaKeman ScotT (Roscoe Pound et al. eds., 1964)).

100 Letter from Henry J. Friendly to Felix Frankfurter 1 (July 8, 1927) (on file with FF-LC, supra note 34, Box 56, Folder "Friendly, Henry J. 1927-1937").

101 Id.

102 Id. at 2-3; cf. Friendly-Epsteins Interview, supra note 72, pt. IV, side 2, at 6 (recalling "delight" over Williston's Socratic style).

103 Letter from Friendly to Frankfurter (Feb. 23, 1957), supra note 89.

104 Letter from Henry J. Friendly to Felix Frankfurter (Dec. 5. 1953) (on file with FF-LC, supra note 34, Box 56, Folder "Friendly, Henry J. 1953-1955 \#2") ("[I]nternal questioning, which has never altogether left me, whether I made the right choice in going after the LL.B. rather than the Ph.D. One of our friends probably hit the nail on the head when she said I really wanted both."); Letter from Felix Frankfurter to Henry J. Friendly (Dec. 7, 1953) (on file with FF-LC, supra note 34, Box 56, Folder "Friendly, Henry J. 1953-1955 \#2") ("“One of our friends' I strongly suspect did hit the nail on the head, except I do see why she did say that you should have gone after both an LL.B. and a Ph.D. Intrinsically you did."). 
Friendly won every accolade at Harvard Law School. He was the first student ever to graduate summa cum laude. ${ }^{105}$ In what may be more myth than fact, Friendly reputedly attained the highest grade point average, an eighty-six, or $\mathrm{A}++$, since Brandeis. ${ }^{106}$ The mythologizing of Henry Friendly began long before he had become a judge. By his "mid-twenties," Friendly had become a law school "legend." 107 Frankfurter wrote "that of all men who came under my scrutiny during my twenty-five years at the School, he was one of the three towering figures."108

105 Harvard Confers 1800 Degrees and Honors Work of 13 Savants, CHRISTIAN SCI. MoN., June 23, 1927, at 1; Over 200 Undergraduates Gain Honors in Graduation Awards, HARV. CRIMSON, June 23, 1927.

106 Secretary Nearly Ties Rank, supra note 38, at 1 (explaining grading scale for Friendly's class when "[f]ew maintained a 70 average, and almost none out of the hundreds who graduate from the law school each year maintain an 80 average"; Friendly led class all three years with yearly averages of eighty-three, eighty-six, and eightyeight). Compare id. (claiming Brandeis had eighty-seven average, one point higher than Friendly's), with id. (recalling Brandeis's ninety-seven average on different grading scale). See also Letter from Austin Wakeman Scott to Monte Lemann (May 28, 1946) (on file with Austin Wakeman Scott Papers, Harvard Law School, Special Collections Library, Box 11, Folder 11-8):

It is true enough that Henry Friendly's 86 topped my 85 . It is by no means true that this was the highest mark ever given. I have not got a list of A's between 1870, when examinations were first given, and 1880. I have, however a list of A's ever given since 1880. The highest mark on that list is Ezra Thayer who got 93. Pretty regularly threr [sic] were marks of 86 and upward. The last one before Friendly was one in 1902.

Indeed, Brandeis doubted his status as having the highest average. According to Friendly:
"Now look," he said ... "I'll give you some advice." He said: "For years, it has been said that I had the highest record ever made at the Harvard Law School. It wasn't true at all." He said: "They'd started changing the grading system even then." And where he had a 95 or something, he said, there'd been people a few years earlier who'd had 99s and whatnot. He said: "I had the feeling that if people wanted to say I had the highest grade at the Harvard Law School, it was not for me to contradict them!"

Friendly-Epsteins Interview, supra note 72 , pt. V, side 1 , at 7 . On the highest average since Brandeis, Friendly said: "Yeah, probably not true at all. Probably been people shortly after Brandeis had grades in the 90 s, but they gradually changed the system. An 86 was quite a good grade." Id. It is safe to say that Friendly attained the highest average of his generation. Cf. Landis $\mathrm{COH}$, supra note 64 , at 32 (recalling his averages of seventy-five in first-year and eighty-two overall, two years before Friendly).

107 Freund, In Memoriam, supra note 76, at 1715.

108 Letter from Felix Frankfurter to Learned Hand (Mar. 31, 1960) (on file with FFLC, supra note 34, Box 65, Folder "Hand, Learned 1960-61 \#41"); see also Letter from Frankfurter to Attorney General Herbert Brownell 1-2 (Jan. 14, 1957) (on file with Hand 
Friendly was elected president of the fortieth volume of the Harvard Law Review. He also authored a Brandeis-inspired and Frankfurter-supervised article, ${ }^{109}$ The Historic Basis of Diversity Jurisdiction, published in the Review's next volume. ${ }^{110}$ The article, which Friendly and Frankfurter originally intended as the first chapter of a book, ${ }^{111}$ nearly called for the abolition of diversity jurisdiction, a position Friendly later championed. ${ }^{112}$ Revealing his modesty and pessimism, Friendly deemed the article worthy of the "waste basket," 13 not the Review. 114

During Friendly's second year, Frankfurter tapped him to clerk for Brandeis. ${ }^{115}$ Frankfurter had made Brandeis aware of Friendly's intellectual prowess. "Your report of Friendly \& others of your students is cheering," Brandeis replied. ${ }^{116}$ Frankfurter and Brandeis envisioned Friendly as a future professor, but they began to lose him to another career path.

\section{The Battle with Buckner}

During his second-year summer, Friendly worked for the U.S. Attorney for the Southern District of New York, Emory Buckner. Frankfurter procured a New York apartment for his three best students, Friendly, Landis, and Corcoran, so they could work for him and meet Buckner, Cardozo, the

Papers, supra note 57, Box 105D, Folder 105D-22) ("He is one of the three men who, in my twenty-five years at the Harvard Law School, o'ertopped even the men whom we regarded as men of distinction and whom I believe you would acknowledge as such at the New York bar.").

${ }^{109}$ Letter from Louis D. Brandeis to Felix Frankfurter (Apr. 2, 1925), reprinted in 5 LETTERS OF LDB, supra note 58, at 170; Letter from Henry J. Friendly to Felix Frankfurter 2-3 (July 20, 1927) (on file with FF-LC, supra note 34, Box 56, Folder "Friendly, Henry J. 1927-37 \#1"); Letter from Frankfurter to Brownell (Jan. 14, 1957), supra note 108 , at 4.

11041 HARV. L. REV. 483 (1928).

111 Letter from Henry J. Friendly to Lawrence W. Maher (Jan. 23, 1984) (on file with Friendly Papers, supra note 72, Box 221, Folder 221-1); Friendly-Epsteins Interview, supra note 72, pt. VIII, side 1, at 6.

112 Henry J. Friendly, In Praise of Herbert Wechsler, 78 CoLuM. L. REV. 974, 97677 (1978).

113 Letter from Friendly to Frankfurter (July 20, 1927), supra note 109, at 2.

114 Letter from Henry J. Friendly to Felix Frankfurter (circa fall 1927) (on file with FF-HLS, supra note 69, pt. III, reel 25, at 160) ('I'm flattered to think that you feel the diversity thing worthy of H.L.R. I still have doubts and I fancy E.M.G. [Law Review president Erwin Griswold] will have more.").

115 Friendly-Epsteins Interview, supra note 72, pt. IV, side 2, at 8.

116 Letter from Louis D. Brandeis to Felix Frankfurter (Mar. 14, 1926) (on file with FF-LC, supra note 34, Box 27, Folder "Brandeis, Louis D. 1926 \#27"), reprinted in 5 LETTERS OF LDB, supra note 58, at 210. 
Hands, and Mack at nightly bull sessions. ${ }^{117}$ Buckner, however, was dissatisfied with his office's legal research during the Daugherty-Miller corruption trial of two Harding administration officials. ${ }^{118}$ Frankfurter lent him Friendly and Corcoran, and Buckner paid them out of his own pocket. ${ }^{119}$

Frankfurter's law classmate and fellow assistant U.S. attorney under Henry Stimson, Buckner rivaled Frankfurter in another respect-as a mentor and talent scout. The former lead partner at the Root, Clark firm, Buckner wanted Friendly to work there. That fall, Frankfurter asked Friendly to delay his Brandeis clerkship and accept a fourth-year research fellowship that Frankfurter intended to make an unstated prerequisite for the clerkship. ${ }^{120}$ Buckner advised Friendly to decline the fellowship, clerk for Brandeis, then work for Root, Clark. ${ }^{121}$ Frankfurter believed that Buckner was interfering with the aim of the Brandeis clerkship-Friendly's return to Harvard Law School to teach. ${ }^{122}$ Buckner had two important allies-Friendly's parents.

Friendly's parents, concerned about their son becoming a professor, arranged two unusual pre-clerkship meetings with Brandeis, first with Friendly's parents then with Friendly alone. On October 28, 1926, Brandeis wrote Frankfurter:

Mr. and Mrs. Friendly were in for an hour. Their misapprehensions as to facts \& relative values of Practicing Lawyer v. Professor of Law, are many. Most of the time, after their recital, was spent in disabusing their minds.

117 Friendly-Epsteins Interview, supra note 72, pt. V, side 1, at 3-4.

118 See MARTIN MAYER, EMORY BUCKNER 181 (1968). Miller was convicted and served 18 months; Daugherty, Harding's attorney general, was not because one juror voted to acquit. See id. at 209-36.

${ }^{119}$ Friendly-Epsteins Interview, supra note 72, pt. V, side 1, at 3-4.

${ }^{120}$ Letter from Felix Frankfurter to Louis D. Brandeis (Sept. 20, 1925) (on file with LDB-Louisville, supra, reel 49, at 212-23); Letter from Felix Frankfurter to Louis D. Brandeis (Sept. 28, 1926) (on file with LDB-Louisville, supra, reel 49, at 282-83); Letter from Felix Frankfurter to Louis D. Brandeis 1-3 (Nov. 12, 1928) (on file with Brandeis Papers, University of Louisville [hereinafter LDB-Louisville], reel 49, at 527-29); Letter from Felix Frankfurter to Louis D. Brandeis (Dec. 7, 1932) (on file with FF-LC, supra note 34, Box 118, Folder "Oxford Correspondence Research Fellowship 1932-34").

${ }^{121}$ Letter from Felix Frankfurter to Emory Buckner (Nov. 30, 1926) (on file with FF-LC, supra note 34, Box 31, Folder "Buckner, Emory R. 1926 \#22"); Letter from Emory Buckner to Felix Frankfurter 1 (Dec. 21, 1926) (on file with FF-LC, supra note 34, Box 31, Folder "Buckner, Emory R. 1926 \#22"); Friendly-Epsteins Interview, supra note 72 , pt. IV, side 2 , at 9 .

122 Letter from Henry J. Friendly to his parents 4 (Oct. 5, 1926) (on file with Friendly Papers, supra note 72, Box 234, Folder 234-1) (recounting lunch with Frankfurter and indicating that "I am thinking pretty seriously of taking the year, tho that does not necessarily or even probably point to teaching"). 
(a) The only definite advice I gave them was to leave their son alone; to let him make up his own mind \& not merely to say so, but let him see \& know that they will be happy in whatever decision he makes. I put this as strongly as I could; \& I think they understood me.

(b) I definitely refused to transmit through them any advice to the son. They wanted specifically to know whether I advised him to take a post graduate year at C[ambridge]. I said I would not advise on that unless I talked with the son etc. And I agreed that I would see him, if he comes here Christmas week. ${ }^{123}$

Brandeis agreed to meet Friendly on November 24, 1926,124 and instructed Frankfurter not to come to Washington until after Friendly's visit. "His father seemed to think the son was being subjected by you and [Mack] to "undue influence,"' Brandeis wrote Frankfurter. ${ }^{125}$

Brandeis may have reacted to his own family's pressure to become an academic. ${ }^{126}$ Instead of teaching, Brandeis made millions in private practice $^{127}$ and earned a reformist reputation as the "People's Attorney."128 As Brandeis biographer Philippa Strum suggested, "[i]t may be that Brandeis's encouragement of academic careers (mixed with public service) for Frankfurter and for his own law clerks was something of a substitute for the life Brandeis would have led had he been a more obedient son and followed his parents' wishes."129 Brandeis thought his best clerks could do the most good as law professors. For Friendly, Brandeis wanted to remove

${ }^{123}$ Letter from Louis D. Brandeis to Felix Frankfurter 2 (Oct. 28, 1926) (on file with FF-LC, supra note 34, Box 27, Folder "Brandeis, Louis D. 1926 \#30"), reprinted in 5 LETTERS OF LDB, supra note 58, at 238.

${ }^{124}$ Letter from Louis D. Brandeis to Felix Frankfurter (Nov. 1, 1926) (on file with FF-LC, supra note 34, Box 27, Folder "Brandeis, Louis D. 1926 \#30").

${ }^{125}$ Letter from Louis D. Brandeis to Felix Frankfurter 1-2 (Nov. 9, 1926) (on file with FF-LC, supra note 34, Box 27, Folder "Brandeis, Louis D. 1926 \#30"), reprinted in 5 LETTERS OF LDB, supra note 58, at 244 . Friendly incorrectly recalled his initial meeting with Brandeis as an interview. Letter from Henry J. Friendly to Melvin Urofsky and David Levy (June 14, 1967) (on file with Urofsky Papers, SUNY-Albany Special Collection and Archives, Box 217, Folder 217-5). Rather, the meeting concerned whether Friendly should take the fourth-year fellowship before his clerkship. Thus, in Friendly's case, Brandeis adhered to his practice of not interviewing clerks. $C f$. UROFSKY, supra note 37 , at $834 \mathrm{n} .465$ (relying on Friendly's erroneous recollection to conclude: "Henry Friendly may have been the only one to have a job interview"); see supra note 56.

${ }^{126}$ Letter from Brandeis to Nagel (July 12, 1879), supra note 42, reprinted in 1 LETTERS OF LDB, supra note 41, at 39.

127 MASON, supra note 38, at 591.

128 UROFSKY, supra note 37 , at 154.

129 STRUM, supra note 49 , at 360 . 
parental pressure from the equation; Friendly's parents heeded Brandeis's advice and left their son alone. ${ }^{130}$

After Christmas break, Friendly declined Frankfurter's fellowship in favor of the Brandeis clerkship. "I am sorry for Friendly's Decision if it disappoints you; but I look forward to having him next year," Brandeis wrote Frankfurter. ${ }^{131}$ Frankfurter was disappointed because of Harvard's dimming prospects of landing Friendly. Brandeis thought he could talk Friendly into a Harvard professorship. First, he wanted to see if Friendly lived up to his billing.

\section{B. Friendly's Clerkship Experience}

Friendly arrived in Brandeis's chambers amid great fanfare. The Christian Science Monitor's front page story about Friendly's clerkship began: "[t]he two highest ranking scholars in the history of Harvard Law School will become intimately associated in their work this month."132 Because of the publicity, Friendly described his first day as "a very embarrassing experience." 133 Brandeis, however, took it in stride.

Friendly did not live, as prior clerks did, in Brandeis's Kalorama apartment building at 2205 California Street. Short of funds, Friendly shared an apartment with Harlan Fiske Stone clerk and former Columbia Law Review editor-in-chief Francis X. Downey nearly a mile from Brandeis's apartment at 2701 Connecticut Avenue. ${ }^{134}$

Friendly's idealization of Brandeis began during his first days in chambers. Friendly marveled at Brandeis, whom Roosevelt referred to as "Isaiah," whose chiseled cheekbones and deep-set eyes reminded many people of Abraham Lincoln, and whose knowledge of law and business was encyclopedic. Friendly wrote Frankfurter:

[M]y hero worship is beginning. When the Justice begins to discourse on the manufacturers in the ' $80 \mathrm{~s}$, or on the difference between corn prices in

${ }^{130}$ Letter from Brandeis to Frankfurter (Nov. 9, 1926), supra note 125.

131 Letter from Louis D. Brandeis to Felix Frankfurter (Jan. 21, 1927) (on file with FF-LC, supra note 34, Box 27, Folder "Brandeis, Louis D. 1927 \#32").

132 Secretary Nearly Ties Rank, supra note 38, at 1.

133 Friendly-Epsteins Interview, supra note 72, pt. V, side 1, at 7.

134 Letter from Friendly to Frankfurter (circa fall 1927), supra note 114, at 1-2 ("Contrary to expectations, I'm rooming with Downey. Tom's [Corcoran, a departing Holmes's clerk] quarters didn't seem to me so palatial as they evidently had to him, and apartments for one proved quite beyond my resources. Downey is in every respect a pleasant surprise; my idea that he resembled other editors-in-chief that we have known was completely erroneous."); see also Friendly-Epsteins Interview, supra note 72, pt. V, side 1, at 10; City of Washington, D.C., CITY DIRECTORY 666, 1852 (1928). 
1925 and 1926, it seems incredible that this is the man who knows more law than almost all the rest of the Court together. ${ }^{135}$

Friendly overcame his awe of Brandeis, learned a lot from the Justice, and ranked among his best clerks, such as Secretary of State Dean Acheson (especially Acheson's second year), Harvard Law Professor Paul Freund, Harvard Law Dean James Landis, future industrialist Robert Page, and Wisconsin Law Professor Willard Hurst. ${ }^{136}$

Due to his idealization of Brandeis, Friendly often overlooked the Justice's weak interpersonal skills. Unlike some Brandeis clerks, Friendly was not put off by the Justice's coldness or aloofness. ${ }^{137}$ Friendly's shy, standoffish demeanor was a perfect match. "While he did not initiate much, he was always very pleasant, always willing to talk, very appreciative of what you did for him," Friendly recalled. "He was neither aloof nor warm."138 Friendly searched for a better description: "I have come up with 'benign.' He was kindly but always kept the appropriate distance."139 Friendly did not mind working in relative isolation, meeting with Brandeis twice a day, once in the morning and once in the afternoon, for twenty- to thirty-minute increments. ${ }^{140}$

The Brandeis-Friendly relationship was based on mutual admiration of each other's talents, not friendship. Privately, Friendly understood the

135 Letter from Friendly to Frankfurter 3 (circa fall 1927) supra note 114, at 3; see also Letter from Henry J. Friendly to James Landis 2 (Nov. 26, 1927) (on file with Landis Papers, supra note 38, Box 5, Folder "1925-1933 Friendly, Henry") ("Of course, I like the job. On the other hand, I'm less enthusiastic than you were over the city.").

136 See Letter from Felix Frankfurter to Dean Acheson (May 12, 1937) (on file with FF-LC, supra note 34, reel 11, at 233) (reporting that Hurst was "the best secretary, professionally speaking, [Brandeis] has ever had").

${ }^{137}$ Interview by Lewis Paper with Willard Hurst, in Madison, Wis. 1 (May 31, 1980) (describing clerkship as "lonesome job" and Brandeis as "very businesslike"); Paper-Sutherland Interview, supra note 70, at 1 (stating that Brandeis was "[n]ot an easy person to be intimate with"); Interview by Lewis Paper with Nathaniel L. Nathanson, in Washington, D.C. 3 (Dec. 17, 1980) (describing Brandeis as "cold and formal" and referring to his "alloofness" [sic]); Interview by Lewis Paper with Louis Jaffe, in Cambridge, Mass. 1 (Feb. 10, 1981) (noting that they communicated by slipping paper under each other's doors, and describing Brandeis as a "very remote, distant person"); Hendrik Hartog, Snakes in Ireland: A Conversation with Willard Hurst, 12 LAW \& HIST. REV. 370, 375 (1994) (describing clerkship as "not a great deal of buddy-buddy" and Brandeis as "very reserved"); Nathanson, supra note 71, at 12 ("The personal contact was almost always brief.").

138 Paper-Friendly Interview, supra note 85, at 6-7.

${ }^{139}$ Letter from Henry J. Friendly to Lewis Paper (Dec. 29, 1980) (on file with Paper Papers, supra note 56, Box 1, Folder 1-3).

${ }^{140}$ Paper-Friendly Interview, supra note 85 , at 1. 
frustrations and isolation of subsequent clerks. ${ }^{141}$ Years later, Friendly wrote 1934 Term clerk Nathaniel Nathanson:

Your paper on Brandeis reminded me of the question which Judge Learned Hand so often asked me, "I know you respected him, but did you really like him?"- an attitude toward Justice Brandeis which I am sure Judge Hand would have found very difficult to fathom. I always answered, "Yes," although I was never too sure that I really meant it. I would have been even less sure if our relations had been as detached as seems to have been the case with you seven years later. ${ }^{142}$

Brandeis worked in his office in the second apartment much more during Friendly's clerkship than in later years when the Justice worked in his private residence. ${ }^{143}$ Friendly, moreover, proved himself worthy of his accolades. As Landis recalled: "[O]nce you proved yourself to him, and that would take maybe two, three weeks, namely that you were trained, he was extremely generous to you. He took you in, substantially as a junior partner in his firm." 144

Friendly matched or surpassed Brandeis's capacity for hard work. Brandeis worked from about 5-6 a.m. until about 6 p.m. ${ }^{145}$ Friendly, like

141 See Letter from Brandeis to Frankfurter (Oct. 28, 1926), supra note 123; Letter from Nathaniel L. Nathanson to Felix Frankfurter 1 (Mar. 4, 1935) (on file with FF-LC, supra note 34, Box 127, Folder "Brandeis, Louis D. 1890-38") (describing unhappiness and feelings of "uselessness"). Compare Letter from David Riesman to Felix Frankfurter 2 (Nov. 21, 1935) (on file with FF-LC, supra note 34, Box 127, Folder "Brandeis, Louis D. 1890-38") ("We have had several good scraps about policy, but remembering your warning, I don't push him when I see his mind is made up ...."), with David Riesman, Notes for an Essay on Justice Brandeis 1-5 (May 22, 1936) (on file with FF-LC, supra note 34, Box 127, Folder "Brandeis, Louis D. 1890-38") (denigrating clerkship) and Interview by Lewis Paper with David Riesman, in Cambridge, Mass. 1 (May 5, 1981) (on file with Paper Papers, supra note 56, Box 1, Folder 1-3 "Paper Ints. Part I") (describing himself as "very ambivalent about my work with Brandeis. I was very critical of him. But I also felt that I had let him down, and I felt terribly guilty about that.").

142 Letter from Henry J. Friendly to Nathaniel L. Nathanson (June 3, 1963) (on file with Friendly Papers, supra note 72, Box 212, Folder 212-3) (referencing Nathanson, supra note 71).

143 Id.

- 144 Landis COH Interview, supra note 64, at 37-38.

145 Id. at 65-66 (recalling Brandeis started work around 6 a.m., never worked late, and went home around 6 p.m. or 7 p.m.); Paper-Friendly Interview, supra note 85, at 1 ("Brandeis would arrive at the office at 5 or 6 o'clock in the morning and do his best work before I arrived, which was usually around 8:30 [a.m.]"); Interview by Lewis Paper with H. Thomas Austern, in Washington, D.C. 1 (Jan. 12, 1981) (on file with Paper Papers, supra note 56, Box 1, Folder 1-3 "Paper Ints. Part l") (recalling Brandeis "got up about 5 [a.m.] and did most of his work then"). 
other Brandeis clerks, started at 8:30 a.m. or 9 a.m. and often worked late. ${ }^{146}$ Friendly did not seem to mind. Years later, Justice Cardozo asked: "Friendly, did you ever have to work as hard in your life as the year you were with Brandeis?"147 Friendly replied: "Mr. Justice, I've worked harder both before and since."148 Friendly referred to his third year of law school, when he worked from 9 a.m. to 11 p.m. as a full-time student and president of the Harvard Law Review. 149

Brandeis noticed Friendly's work ethic. "Don't you ever send me another man like Friendly," he reputedly told Frankfurter. 150 "Why not?" Frankfurter asked.151 "If you do," Brandeis replied, "I'll have nothing left to do."152 During the 1927 Term, Brandeis wrote his daughter, Susan: "There is even enough work on hand to satisfy my voracious secretary [Friendly]."153 Brandeis wrote Frankfurter about Friendly's replacement, Irving Goldsmith: "G[oldsmith]will have a hard time as the successor to F[riendly]."154

Like most Brandeis clerks, Friendly searched the Library of Congress for the facts that Brandeis so dearly loved and the footnotes that characterized his opinions. In Untermyer $v$. Anderson, ${ }^{155}$ the Court invalidated a ten-day retroactive gift tax on due process grounds over Holmes's and Brandeis's dissents. ${ }^{156}$ Holmes wrote a pithy dissent. ${ }^{157}$ Brandeis sent Friendly to the library, where Friendly found fifteen prior federal tax acts, as well as tax

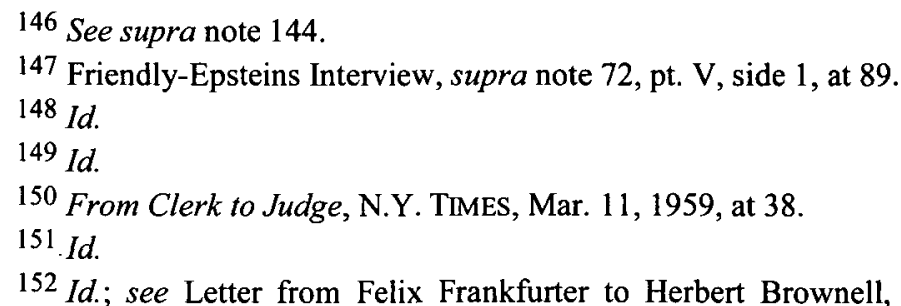
7) (on file with Hand Papers, supra note 57, Letter from Milton Rosenkrantz to Thomas C. Hennings, Jr., Senator 3 (July 8, 1959) (on file with Friendly Papers, supra note 72, Box 235, Folder "Scrapbook 1959-present") (hearing Frankfurter story at fiftieth anniversary celebration of Harvard Law Review).

${ }^{153}$ Letter from Louis Brandeis to Susan Brandeis (May 20, 1928), reprinted in FAMILY LETTERS, supra note 42, at 465; see infra text accompanying note 327.

154 Letter from Louis D. Brandeis to Felix Frankfurter (Feb. 11, 1928), reprinted in 5 LETTERS OF LDB, supra note 58, at 323. Goldsmith was so bad that Brandeis nearly replaced him. Letter from Louis D. Brandeis to Felix Frankfurter (Oct. 7, 1928), reprinted in 5 LETTERS OF LDB, supra note 58, at 358-59; Letter from Louis D. Brandeis to Felix Frankfurter (Oct. 12, 1928), reprinted in 5 LETTERS OF LDB, supra note 58, at 359-60; Letter from Louis D. Brandeis to Felix Frankfurter (Oct. 15, 1928), reprinted in 5 LETTERS OF LDB, supra note 58, at 361 .

155276 U.S. 440 (1928).

$156 \mathrm{Id}$. at 445.

${ }^{157} I d$. at 446 (Holmes, J., dissenting). 
statutes from other countries, all of which had retroactive effects. ${ }^{158}$ Friendly also learned from the Department of Commerce about retroactive tariffs. 159 "To what Justice Holmes has said," Brandeis began his dissent, "I add this"160 _ eight footnote-laden, fact-filled pages based on Friendly's research that eviscerated the majority opinion and caused Holmes to question the publication of his dissent. ${ }^{161}$

Friendly produced similar research for Brandeis's dissent in Louisville Gas \& Electric Co. v. Coleman, ${ }^{162}$ which invalidated Kentucky's recording tax on mortgage bonds on equal protection grounds for exempting loans of less than sixty months from the tax. ${ }^{163}$ Friendly found the state legislative history, which showed that shorter loans were held by in-state residents already subject to property taxes, but longer loans were held by out-of-state residents not subject to property taxes. ${ }^{164} \mathrm{He}$ also discovered that nine states had passed similar statutes to reduce property tax inequalities between short and long-term loans, individuals and corporations, and in-state and out-ofstate residents. ${ }^{165}$ Friendly was sure that other Justices, after reading Brandeis's memo, would switch their votes. ${ }^{166}$ Only Holmes and Harlan Fiske Stone joined. Friendly was upset that the Court was setting a bad precedent. 167 "Don't worry," Brandeis said, “A future Court will pay no more heed to this decision than today's Court is paying to the cases we cited to them."168

${ }^{158}$ Louis D. Brandeis Papers, Harvard Law School Library [hereinafter LDB-HLS Papers], reel 39, at 78-99 (handwritten notes), 100-05 (six-page memo); Henry J. Friendly, Mr. Justice Brandeis: The Quest for Reason, 108 U. PA. L. REV. 985, 991-92 (1960) [hereinafter Friendly, Quest for Reason].

${ }^{159}$ LDB-HLS Papers, supra note 158, reel 39, at 78-79.

160 Untermyer, 276 U.S. at 446 (Brandeis, J., dissenting).

161 Friendly, Quest for Reason, supra note 158, at 991-92; LDB-HLS Papers, supra note 158 , reel 39 , at 199 .

162277 U.S. 32 (1928).

$163 \mathrm{Id}$. at $40-41$.

164 Paper-Friendly Interview, supra note 85, at 2.

165 Friendly, Quest for Reason, supra note 158, at 992-93; LDB-HLS Papers, supra note 158, reel 35, 901-07 (seven-page memo), 908-17 (handwritten notes about other states), 974-76 (inserting material as footnote).

166 Friendly, Quest for Reason, supra note 158, at 993.

$167 \mathrm{Id}$.

168 Id; see Letter from Henry J. Friendly to James Landis 4 (Apr. 7, 1928) (on file with Landis Papers, supra note 38, Box 5, Folder "1925-1933 Friendly, Henry") ("As usual, the most important cases see L.D.B. and O.W.H. in a minority. How long will they have to wait before their views are translated into law?"); Friendly-Epsteins Interview, supra note 72, pt. V, side 2, at 103-04; Paper-Friendly Interview, supra note 85, at 2-3; PAPER, supra note 51, at 253; Eugene V. Rostow, The Democratic Character of Judicial 
Friendly and Brandeis shared a common obsession with federal jurisdiction. Friendly learned from Brandeis how to be a "jurisdiction hound." 69 Just two years after the 1925 Judiciary Act had given the Court control over its docket, Brandeis reviewed all the cert petitions, then divided them into two stacks: grant or deny. Friendly reviewed the grant pile

to see if any lacked jurisdiction. Or if there was some other reason the Court couldn't reach the issue on appeal, I would look for that [t]oo. This was all before there was a jurisdictional statement in the brief. In fact one day I suggested that to him, and he thought it was a pretty good idea. I believe that's the genesis of the present rule. ${ }^{170}$

Friendly helped Brandeis avoid constitutional decisions on jurisdictional grounds. "I remember one case we discussed the jurisdictional point of whether a municipal ordinance was a state statute," Friendly recalled. "This was important because there was a right to appeal only from decisions of the state's highest court concerning statutes, not other actions."171 Brandeis admired his clerk's jurisdictional instincts. When Congress wanted to limit diversity jurisdiction, and Frankfurter needed help drafting such legislation, Brandeis suggested that "Friendly can, I think, be drafted by you. He has become keenly interested in jurisdictional matters." 172

Friendly's biggest contribution during the 1927 Term came through his incisive typewritten comments on Brandeis's multiple printed drafts of his opinions. Friendly recalled:

After he completed a draft, he wanted you to go through it carefully to check citations and to make criticisms and suggestions. He was very receptive to them. These could include whole paragraphs and sometimes pages of revisions, and [former clerk] Tommy Austern always said that

Review, 66 HARV. L. REV. 193, 223 (1952) (quoting Brandeis that "no case is ever finally decided until it is rightly decided").

169 Paper-Friendly Interview, supra note 85, at 1.

170 Id. at 2.

$171 \mathrm{Id}$.

172 Letter from Louis D. Brandeis to Felix Frankfurter (Mar. 4, 1928) (on file with FF-LC, supra note 34, Box 27, Folder "Brandeis, Louis D. 1928 \#36"), reprinted in 5 LETTERS OF LDB, supra note 58, at 327; see also Letter from Louis D. Brandeis to Felix Frankfurter (Mar. 10, 1928) (on file with FF-LC, supra note 34, Box 27, Folder "Brandeis, Louis D. 1928 \#36") (suggesting Friendly's research for Frankfurter and Landis's annual Business of the Supreme Court); Letter from Louis D. Brandeis to Felix Frankfurter (Mar. 16, 1928) (on file with FF-LC, supra note 34, Box 27, Folder "Brandeis, Louis D. 1928 \#36"), reprinted in 5 LETTERS OF LDB, supra note 58, at 330 (reminding Frankfurter to contact Friendly). 
Brandeis would always use the clerk's suggestions unless they were really worse than his original draft. ${ }^{173}$

Friendly often suggested changes and made his most important contributions to one of Brandeis's famous dissents, Olmstead v. United States. ${ }^{174}$

In Olmstead, as in many cases in which he knew he wanted to dissent, Brandeis wrote a memorandum before oral argument. He did this not to persuade other Justices, as Brandeis "was not a button-holer," but "to make sure that he did not hold up the Court."175 In the Olmstead memorandum's early stages, Friendly compiled the wiretapping laws in all forty-eight states, then discovered all the statutes in the phone companies' amicus brief. 176

Olmstead differed from other cases that term because Brandeis's interest in privacy law spanned nearly forty years. In 1890, Brandeis had co-authored with Samuel Warren the ground-breaking Harvard Law Review article, The Right to Privacy, and had coined the phrase "the right to be let alone" later included in Olmstead. ${ }^{177}$ Brandeis had dissented earlier that term in Casey v. United States, ${ }^{178}$ a similar case where Holmes's majority opinion affirmed the conviction of a lawyer for selling morphine to prisoners at the behest of undercover police officers. ${ }^{179}$ Brandeis dissented because "officers of the Government instigated the commission of the alleged crime" 180 and " $[t] \mathrm{o}$ protect [the government] from [the] illegal conduct of its officers."181

In Olmstead, Brandeis objected to the convictions of Olmstead and seventy others in a liquor smuggling operation based on five months of wiretaps of homes and offices in violation of Washington state law. ${ }^{182}$ For nearly two weeks before oral argument, Brandeis redrafted a memorandum/dissent. Friendly made two major suggestions about the memo's organization. First, before oral argument, he suggested beginning with the decisive constitutional questions, followed by the "unclean hands" doctrine based on the government's violations of state law. ${ }^{183}$ Second,

173 Paper-Friendly Interview, supra note 85, at 2.

174277 U.S. 438, 471 (1928) (Brandeis, J., dissenting).

175 Paper-Friendly Interview, supra note 85 , at 3.

176 LDB-HLS Papers, supra note 158, reel 36, at 622 (state law footnotes), 852-73 (state wiretapping laws); LEONARD BAKER, BRANDEIS AND FRANKFURTER 214 (1984).

177 Samuel D. Warren \& Louis D. Brandeis, The Right to Privacy, 4 HARV. L. REV. $193,193(1890)$.

178 276 U.S. 413 (1928).

179 Id. at $416,419,420$.

${ }^{180} \mathrm{Id}$. at 421 (Brandeis, J., dissenting).

181 Id. at 425.

182 Olmstead v. United States, 277 U.S. 438, 471 (1928) (Brandeis, J., dissenting).

183 Paper-Friendly Interview, supra note 85, at 2; Friendly-Epsteins Interview, supra note 72 , pt. V, side 2, at 101 . 
inspired by questions at oral argument, Friendly suggested rearranging the constitutional section, beginning with questions of "constitutional adaptability" 184 and John Marshall's line in McCulloch that "we must never forget ... that it is a constitution we are expounding"185 before proceeding to the Fourth and Fifth Amendment arguments. Friendly had recommended "rearrangements" of Brandeis's opinions in the past, but never in a dissent of this magnitude and on a subject on which Brandeis was an expert. ${ }^{186}$ Friendly helped transform Brandeis's drafts into one of the most canonical dissents in American law.

Brandeis should have disregarded one of Friendly's Olmstead suggestions. In January 1928, television was in the experimental stage. Brandeis, an austere man, never owned a television and in 1928, like most Americans, had never seen one. He had, however, read a January 13 Associated Press story titled Television Sets in Homes Reproduce Studio Scenes. ${ }^{187}$ In an Olmstead draft, Brandeis wrote: "By means of television, radium, and photography, there may some day be developed ways by which the Government could, without removing papers from secret drawers, reproduce them in court and lay before the jury the most intimate occurrences of the home." 188 It would have been the first reference to television in a Supreme Court opinion. Friendly objected: "Mr. Justice, television really isn't appropriate here. Television doesn't work in a way so that you can take it across a street and beam it into an apartment or building

${ }^{184}$ Letter from Henry J. Friendly to Louis D. Brandeis (Feb. 21, 1928) (on file with LDB-HLS Papers, supra note 158, reel 36, at 685). This phrase is Alexander Bickel's. Bickel, in possession of Brandeis's Papers while working on THE UNPUBLISHED OPINIONS OF MR. JUSTICE BRANDEIS (1957), deciphered the Olmstead drafts, wrote ten insightful summaries of the printed versions, and recognized Friendly's contributions. See LDB-HLS Papers, supra note 158, reel 36, at 575 (first print on February 4), 584 (second print on February 8), 599 (third print on February 9); 610 (fourth print, incorporating Friendly's suggestions, on February 11), 620 (fifth print on February 13), 638 (sixth print on February 13), 646 (seventh print on February 14 and eighth print on February 16), 670 (ninth print, incorporating Friendly's first reorganization suggestions, on February 17), 685-89 (Friendly's memo suggesting reorganization on February 21), 728 (print on February 23), 886 (additional Friendly comments); PAPER, supra note 51, at 310-14.

185 Olmstead, 277 U.S. at 472 (Brandeis, J., dissenting) (quoting McCulloch v. Maryland, 17 U.S. 316, 407 (1819)).

186 LDB-HLS Papers, supra note 158, reel 34, at 959-60 (proposing rearrangement in Del., L., \& W. R. v. Morristown, 276 U.S. 182, 195 (1928) (Brandeis, J., dissenting)); id. at reel 35, at 225 (proposing rearrangement in Great Northern Ry. v. United States, 277 U.S. 172 (1928)); id. at reel 36, at 1 (suggesting "radical rearrangement" in Louisville Gas \& Elec. Co. v. Coleman, 277 U.S. 32 (1928)).

187 Id. at reel 36, at 913; Radio Television to Home Receivers is Shown in Tests, N.Y. TIMES, Jan. 14, 1928, at 1.

188 LDB-HLS Papers, supra note 158 , reel 36, at 928. 
and see what somebody is doing." 189 Brandeis replied: "That's exactly how it works." 190 Friendly produced articles from the Library of Congress confirming his view; Brandeis removed the sentence. Years later, Friendly acknowledged: "[H]e was right! And I was wrong."191

Besides Olmstead, Friendly admired Brandeis's dissents that refused to invalidate state and federal taxation and regulation on equal protection or due process grounds ${ }^{192}$ in Untermyer, Louisville Gas, and especially Quaker City Cab v. Pennsylvania, ${ }^{193}$ where the Court invalidated a Pennsylvania tax on corporations on equal protection grounds. "Although Brandeis applied his due process and equal protection test with an even hand," Friendly later wrote, "he applied it con amore in those cases where the statute under attack tracked his own social philosophy, as in the case of legislation favoring the individual against the corporation or the small business against the large."194 Brandeis's dissents like Quaker City, Friendly wrote, "truly sing."195 Friendly's contributions to Quaker City included a memo with minor substantive edits, cite-checking, and research on other states' franchise taxes. 196

After his clerkship, Friendly realized that Brandeis sometimes idealized state legislatures and imputed wisdom to them not in the record. Several years later in Liggett Co. v. Lee, ${ }^{197}$ Brandeis dissented from the Court's opinion invalidating a Florida law imposing heavier taxes on chain stores. ${ }^{198}$ At the time, Friendly was arguing a case before the Florida Supreme Court, had watched the legislature in action, and reported to Brandeis "that I feared many of the Florida legislators had been more influenced by the independent

189 Paper-Friendly Interview, supra note 85, at 4; PAPER, supra note 51, at 312.

${ }^{190}$ Friendly-Epsteins Interview, supra note 72 , pt. V, side 2, at 101-02; PaperFriendly Interview, supra note 85, at 4; PAPER, supra note 51, at 312.

${ }^{191}$ Friendly-Epsteins Interview, supra note 72, pt. V, side 2, at 102; Paul A. Freund, The Evolution of a Brandeis Dissent, 10 MANUSCRIPTS 18, 22, 24 (Spring 1958), reprinted in MR. JUSTICE 193-98 (Allison Dunham \& Philip B. Kurland eds., 1964).

192 Friendly-Epsteins Interview, supra note 72, pt. V, side 2, at 100.

193277 U.S. 389, 403 (1928) (Brandeis, J., dissenting).

194 Friendly, Quest for Reason, supra note 158, at 993.

195 Id.

196 LDB-HLS Papers, supra note 158, reel 36, at 949 (statement of facts), reel 37, at 33 (memo), 54-62 (state franchise taxes).

197288 U.S. 517 (1933).

198 Id. at 541 (Brandeis, J., dissenting); see Freund, A Law Clerk's Remembrance, supra note 64, at 13-14 (recounting Liggett dissent). 
drug store lobby than by philosophical and sociological ideas with which he credited them; he did not seem amused."199

Friendly believed that Brandeis's passion for pet issues sometimes led him astray and to at least one major disagreement during the 1927 Term between the Justice and his clerk. In Willing v. Chicago Auditorium Ass' $n$, 200 Brandeis's majority opinion declared that no case or controversy existed in a quiet title action. Instead of stopping there, Brandeis also found no constitutional right to a declaratory judgment. ${ }^{201}$ This contradicted Brandeis's oft-stated belief in avoiding constitutional questions. ${ }^{202} \mathrm{He}$ knew that Willing would outrage Yale law professor Edwin Borchard, a proponent of declaratory judgments, who along with other progressives criticized the decision. ${ }^{203}$ Frankfurter informed his federal jurisdiction seminar that "Borchard was surely wrong, for the simple reason that Henry Friendly was Brandeis's law clerk at the time."204

Unbeknownst to Frankfurter, Friendly disagreed with Willing and tried to change Brandeis's mind. ${ }^{205}$ Friendly objected because the declaratory judgment "point hadn't been argued, and I thought for him to make this

${ }^{199}$ Friendly, Quest for Reason, supra note 158, at 994 n.35; see also Paper-Friendly Interview, supra note 85, at 3 ("He didn't laugh or say anything. I'm not sure what he thought.").

200277 U.S. 274,284 (1928).

201 Id. at $288-89$.

202 Letter from Louis D. Brandeis to Felix Frankfurter 15 (June 28, 1923) ("[T]he most important thing we do is not doing.") (on file with Brandeis Papers, Library of Congress, pt. II, reel 33, at 464); Ashwander v. TVA, 297 U.S. 288, 345-49 (1936) (Brandeis, J., concurring); AlEXANDER BICKEL, THE UNPUBLISHEd OPINIONS OF MR. JUSTICE BRANDEIS 17 (1957); Melvin I. Urofsky, The Brandeis-Frankfurter Conversations, 1985 SUP. CT. REV. 299, 313 (1986).

203 Letter from Edwin Borchard to Louis D. Brandeis 1 (Apr. 15, 1927) (on file with LDB-Louisville, supra note 120, reel 49, at 359) (enclosing, E.M.B., Comment, Declaratory Actions as "Cases or Controversies," 36 Y ALE L.J. 845, 853 (1927)); Letter from William H. Taft to Louis D. Brandeis, undated (on file with LDB-HLS Papers, supra note 158, reel 39, at 692) ("Borchard will mourn but he can not by tears change our jurisdiction."); EDWARD A. PURCELL, JR., BRANDEIS AND THE PROGRESSIVE CONSTITUTION 128-32 (2000) (detailing contemporaneous debate about Willing); Edwin W. Borchard, Declaratory Judgments in Federal Courts, 41 YALE L.J. 1195, 1196-97 (1932).

204 Freund, In Memoriam, supra note 76, at 1716.

205 Friendly wrote Brandeis: "I should have thought that a good deal might be said in favor of the constitutionality of the declaratory judgment, at least in a case where the defendant had positively asserted a position adverse to that of the plaintiff." LDB-HLS Papers, supra note 158 , reel 39 , at 577 . Stronger objections must have been orally conveyed. 
comment in advance in an opinion was outrageous."206 Friendly enlisted his roommate, Stone clerk Francis Downey,

to try to get Stone to change Brandeis's mind. I remember one afternoon Stone came over and spent about an hour trying to get Brandeis to take that out of the opinion. But it was without success. He saw the declaratory judgment as a terrible thing. But his opinion on it was like an abortion before the conception. ${ }^{207}$

Friendly wrote after Brandeis's death that "his zeal against the declaratory judgment led to him to deliver . . . what Justice Stone declared to be itself a declaratory judgment against the application of this remedy in the federal courts - a dictum which a unanimous Court, including Brandeis, was obliged to ignore nine years later."208 Friendly viewed Willing as Brandeis's "worst"209 opinion and others agreed. ${ }^{210}$ Willing showed, when it came to the merits, that neither his trusted clerk nor a like-minded Justice could change Brandeis's mind. 211

Despite their Willing disagreement, Friendly admired Brandeis and learned a lot from him even when he did not write opinions. Brandeis encouraged Holmes to write the dissent in Black \& White Taxicab Transfer Co. v. Brown \& Yellow Taxicab \& Transfer Co., ${ }^{212}$ which revealed the incentive to reincorporate across state lines to benefit from federal common

206 Paper-Friendly Interview, supra note 85 , at 4.

$207 \mathrm{Id}$.

${ }^{208}$ Henry J. Friendly, Book Review, 106 U. PA. L. REV. 766, 769 n.19 (1958) [hereinafter Friendly, Bickel Book Review] (reviewing BICKEL, supra note 202); see also Willing v. Chi. Auditorium Ass'n, 277 U.S. 274, 290 (1928) (Stone, J., concurring); Henry J. Friendly, Reactions of a Lawyer-Newly Become a Judge, 71 YALE L.J. 218, 233 (1961) ("[W] hat was wrong about Willing was that Brandeis' zeal for this position prevented him from looking fairly at what was actual and what hypothetical[,] as he later did, and also led him to violate his own maxim by deciding something not remotely presented for decision.") [hereinafter Friendly, Reactions of a Lawyer]; Henry J. Friendly, Mr. Justice Harlan, As Seen by a Friend and Judge of an Inferior Court, 84 HARV. L. REV. 382, 384 n.9 (1971) [hereinafter Friendly, Mr. Justice Harlan] (suggesting Willing was one of Brandeis's "worst" decisions "decided over the violent protest not only of one of his most valued colleagues, Mr. Justice Stone, but, what was even more serious, of his law clerk").

209 Paper-Friendly Interview, supra note 85, at 4; supra note 203.

210 Letter from Felix Frankfurter to Henry M. Hart 2 (Feb. 11, 1959) (on file with FF-HLS, supra note 71, pt. III, reel 33, at 489); Freund, Centennial Memoir, supra note 65, at 788; Erwin Griswold, Foreword: Of Time \& Attitudes-Professor Hart \& Judge Arnold, 74 HARV. L. REV. 81, 91 (1960).

211 Friendly-Epsteins Interview, supra note 72, pt. V, side 2, at 102 ("Oh, nobody was gonna change Brandeis's mind after he'd really made it up.").

212276 U.S. 518 (1928). 
law in diversity cases. 213 "He thought it was an absolute outrage," Friendly recalled of Brandeis. "He wanted Holmes to write the dissent, though, because he had been at it a lot longer."214 Black \& White presaged Brandeis's ground-breaking opinion ten years later in Erie Railroad v. Tompkins ${ }^{215}$ applying state law in diversity cases, which Friendly defended as based on “the Justice's belief that the doctrine of Swift $v$. Tyson contained 'defects, political and social' and produced 'mischievous results' - and that no amount of argument could have led him to think otherwise." 216 Friendly rejected Erwin Griswold's contention that Erie showed Brandeis's "intellectual disinterestedness."217 Brandeis, Friendly contended,

had been pondering [the issue] for at least a decade and probably much longer; and I see nothing wrong in his adhering to a conclusion so formed rather than making a pretense of reexamination either in the discussion leading to the opinion or by granting a reargument in which counsel could not have added anything to what the various Justices themselves had urged. 218

Friendly admired Brandeis for doing his own work and better than anyone else, including Holmes, who turned eighty-seven in March of Friendly's clerkship. One of Friendly's minor complaints about his clerkship was Brandeis's failure to bring Friendly on the Justice's regular visits to Holmes's apartment. Brandeis took him to see Holmes "once. I wish he'd done it more." 219 Holmes would call the office apartment around lunchtime.

213 Id. at 532 (Holmes, J., dissenting).

214 Paper-Friendly Interview, supra note 85, at 5 .

215304 U.S. 64 (1938).

216 Friendly, Reactions of a Lawyer, supra note 208, at 234 .

217 Id. (discussing Griswold, supra note 210, at 91).

${ }^{218}$ Id. See PURCELL, supra note 203, at 132-40 (distinguishing Erie from Willing and arguing that Brandeis wrote Erie as a homage to Holmes).

219 Friendly-Epsteins Interview, supra note 72, pt. V, side 1, at 10; Peppers, Isaiah and His Young Disciples, supra note 51, at 96 n.78.

For Friendly, Brandeis's wife, Alice, was "a real pain in the neck." She hounded Friendly about ensuring that no guest monopolized Brandeis's time at Monday teas or stayed at dinners past his 10 p.m. bedtime. She kept poking Friendly in the ribs when Woodrow Wilson's widow was slow to leave dinner. Alice made Friendly research one of her relatives. "She used to think I was clerk to her as well as to him," Friendly recalled. Paper-Friendly Interview, supra note 85, at 5-6; see also Friendly-Epsteins Interview, supra note 72 , pt. V, side 1, at 9 ("unflattering comments re: Mrs. B omitted").

Brandeis invited Friendly to meetings of leading Zionists "every fifth Sunday," but Friendly "was not actively interested in Zionism and rather looked forward to my Sundays off, I never accepted." Letter from Friendly to Myron Bright (Dec. 6, 1982) (on file with Friendly Papers, supra note 72, Box 220, Folder 220-3); Friendly-Epsteins 
"Hello, young fella. Is your chief there?"220 Friendly often told Holmes that Brandeis was in his downstairs apartment having lunch, but Holmes kept calling. ${ }^{221}$ Occasionally, Holmes would ask Friendly a substantive question. "Young fella," Holmes asked, "is your boss going to be prepared on the ICC case?"222 Friendly said yes. "Well," Holmes replied, "then I guess I won't prepare. An old man's prerogative, you know." 223 After nearly twenty-five years of his own as a federal judge, Friendly questioned whether Holmes had been a "poseur" and "whether my generation was not overly impressed by him."224

In contrast to Holmes, Friendly admired that Brandeis worked as hard on his opinions in ICC cases as he did on his Olmstead dissent. "Of course, he was an absolutely superb technician: really the best in cases like complicated Interstate Commerce Commission cases ....," Friendly recalled. "[W]hen I say the best, of course these aren't the opinions that he'll go down in history for, but his ability to take one of these cases and get at the facts, organize the material-I think he was perfectly tremendous in the way in which he organized things--[b]uild up the opinion."225

Friendly admired Brandeis's "amazing memory" and "a remarkable ability to get to the heart of a matter"226; above all, what Friendly admired most about Brandeis's opinions were their "relentless quality." 227 Friendly quoted Frankfurter that Brandeis's opinions "march step by step towards

Interview, supra note 72, pt. V, side 2, at 104; Paper-Friendly Interview, supra note 85, at 2.

${ }^{220}$ Friendly-Epsteins Interview, supra note 72 , pt. V, side 1, at 10; Paper-Friendly Interview, supra note 85, at 5; PAPER, supra note 51, at 298.

221 See Friendly-Epsteins Interview, supra note 72, pt. V, side 1, at 10.

222 Paper-Friendly Interview, supra note 85, at 4.

223 Id.

224 See Letter from Henry J. Friendly to Michael Boudin 1 (July 2, 1984) (on file with Friendly Papers, supra note 72, Box 221, Folder 221-4). Friendly noted:

Whether intentionally or not, Mr. Wilson seems to have brought out some of [Holmes's] most unlovely aspects. I find nothing very 'adorable' in the soldiers' faith of which Holmes spoke. Some of his more outrageous sayings could have been quoted by Hitler. As the years go on, I wonder how much of a poseur Holmes was and whether my generation was not overly impressed by him.

Id. (commenting on EDMUND WILSON, PATRIOTIC GORE (1962)).

225 Friendly-Epsteins Interview, supra note 72, pt. V., side 2, at 104.

226 Henry J. Friendly, Book Review, 56 YALE L.J. 423, 426 (1947) (reviewing MASON, supra note 40) [hereinafter Friendly, Mason Book Review]; see also PaperFriendly Interview, supra note 85, at 5 ("I remember one time he recited some statistics on barge traffic on the Ohio River, a matter of obvious interest to him. But the next day I went up to the Library of Congress to check it out, and I was amazed that he was right.").

${ }^{227}$ Friendly, Quest for Reason, supra note 158, at 986. 
demonstration, with all the auxiliary reinforcement of detailed proof." Friendly wrote:

No quarter is asked and none is given. Fact is piled on fact, proposition on proposition, until the right doctrine emerges in heavenly glory and the wrong view is consigned to the lowest circle of hell. It has been said, no doubt correctly, that Brandeis' style lacks the magic of those supreme composers of judicial literature, Holmes and Learned Hand. But the judicial Parnassus has room for more than two, and I find deep eloquence in the march of Brandeis' opinions. ${ }^{229}$

Friendly wrote that even Brandeis's unpublished opinions "reveal the concentration of emotion, of intellect, and of hard work that characterize his greatest deliverances." 230 They showed

how deeply Brandeis cared about how much. He was incapable of mediocrity. He gave the same zeal, the same passion for thoroughness, and the same skill in the organization of his materials to contending that a municipal ordinance was not "a statute of any state" within the meaning of the Court's jurisdictional statute as he did in urging that the fourth amendment be applied to prevent "subtler and more far-reaching means of invading privacy" than the fathers had known. 231

Friendly was quoting two cases, King Manufacturing and Olmstead, decided during his clerkship. ${ }^{232}$

But as much as Friendly learned from Brandeis about constitutional avoidance, deference to elected officials, judicial craftsmanship, and a relentless approach to opinion writing, Friendly adopted a different approach to judging. Though he admired Brandeis's passion and willingness to buck conventional wisdom, ${ }^{233}$ Friendly was partial to Learned Hand's strippeddown approach:

228 Id. (quoting Frankfurter, Mr. Justice Brandeis and the Constitution, 45 HARV. L. REV. 33, 104 (1931)); Friendly, Mr. Justice Harlan, supra note 208, at 386-87 (same).

${ }^{229}$ Friendly, Quest for Reason, supra note 158, at 986.

230 Friendly, Bickel Book Review, supra note 208, at 769 .

$231 \mathrm{Id}$.

232 See John P. King Mfg. v. City Council, 277 U.S. 100, 116 (1928) (Brandeis, J., dissenting)); supra text accompanying notes 174-89 (discussing Olmstead v. United States, 277 U.S. 438, 471-72 (1928) (Brandeis, J., dissenting)).

233 Friendly wrote:

Through all these phases of American life, [a biography] will show Brandeis, keenly aware of the deeper currents, sometimes swimming with them and, more often, against them, always informed, thoughtful, deliberate in decision, but resolute and courageous once decision was made. Above all, if it is to be successful, it will 
L.D.B. saw all the choices, but, on the issues that mattered to him, and on which his reputation rests, he had such deep convictions that choice was easy. His great courage lay in his willingness, indeed zeal, to advocate many choices that were highly unpopular. LH had no such convictions; however petty the issue, he saw all the possibilities and was painfully conscious by what slight measure the scales often tipped. Yet he never weaseled or cheated. As he said of Cardozo, he "would often begin by stating the other side better than its advocate had stated it himself." To decide such issues, for fifty years, in all fields of law-not just the great issues that confront the Supreme Court, but those day to day things which are the stuff of the law-with a clarity and sensitivity unrivaled in our time, is to me the mark of the great and, in a true sense, the courageous judge. ${ }^{234}$

Brandeis, unlike Hand or Cardozo, did not "anguish" over making the right decision; he wrote as if he were one hundred percent convinced even if he believed he was only "fifty-one percent right." 235 "The intellectual satisfaction of having arrived at the correct decision meant little to him; the

convey to us something of the spiritual intensity that has marked off Justice Brandeis from almost all other men of his day.

Henry J. Friendly, Book Review, 85 U. PA. L. REV. 330, 330 (1937) (reviewing ALFRED LIEF, BRANDEIS: THE PERSONAL HISTORY OF AN AMERICAN IDEAL (1936)).

234 Letter from Henry J. Friendly to Felix Frankfurter 1-2 (Sept. 25, 1961) (on file with FF-LC, supra note 34, Box 56, Folder "Friendly, Henry J. 1961 \#5"). Friendly recognized:

Brandeis was primarily the advocate in everything that he did, including his work on the bench. He made no pretense, at least in the great constitutional controversies, of keeping his mind in balance until the last word of argument had been said. He had a definite point of view, and he conceived it his task to make this prevail by every proper means. His approach to every problem was the approach of the lawyer handling great causes - ferret out the facts, formulate a position, assess its elements of strength, marshal the considerations in its support, attack the opposition at its weakest point, and pursue that attack until victory was achieved.

Friendly, Mason Book Review, supra note 226, at 424.

235 Ambrose Doskow, A Personal View, 1 CARDozo L. REV. 16, 18-19 (1979) (quoting Brandeis: "The trouble with [Cardozo] is that he thinks he has to be one hundred percent right. He doesn't realize that it is enough to be fifty-one percent right," and quoting Cardozo: "The trouble with that is that when you are only fifty-one percent right, it may be forty-nine percent."); see also Interview by Lewis D. Paper with Benjamin Cohen, in Washington, D.C. 1 (Aug. 13, 1979) (on file with Paper Papers, supra note 56, Folder "Paper Ints. Part I") (quoting Brandeis that "there comes a time when you have to make a decision and choose a course, even tho[ugh] it may be only 51 percent right. And once you've made that decision, you should follow through on it."); Harlan Phillips, Columbia Oral History: Robert Jackson 987 (on file with Jackson Papers, Library of Congress, Box 191, Folder 2) (quoting Brandeis's statement "that the difficulty with this place is that if you're only fifty-five percent convinced of a proposition, you have to act and vote as if you were one hundred percent convinced"). 
true satisfaction came only from the translation of that decision into reality," Friendly wrote. 236 Friendly agreed with Holmes that Brandeis was more of an advocate than a judge. ${ }^{237}$ Yet, when asked about the most superior intellect on the bench or the bar, Friendly replied: "I guess I'd put Brandeis first. I think I'd put Learned Hand next."238 Privately, Friendly recognized Brandeis's strengths and weaknesses and acknowledged that Brandeis sometimes did not live up to Friendly's ideals. ${ }^{239}$ Friendly also did not live up to Brandeis's, rejecting the agenda for the best Brandeis clerks - careers in academia and public service.

\section{BRANDEIS'S INFLUENCE ON FRIENDLY}

The Brandeis clerkship was more than a research assistantship or junior partnership. Brandeis and Frankfurter viewed clerkships as opportunities to identify young legal elites, indoctrinate them with progressive ideas, and encourage them to spread those ideas through law teaching or government service. Brandeis believed that his best clerks should eschew private practice for the public good. These former clerks turned professors and public servants perpetuated the idealization of Brandeis as well as the federal judiciary.

Brandeis's post-clerkship mentoring and career counseling set his clerkship apart from Holmes's or any other judge's, perhaps in history. If his clerk performed well, Brandeis wanted him to be a law professor. And if the clerk was exceptional, Brandeis wanted him teaching at Harvard Law

236 Friendly, Quest for Reason, supra note 158, at 986; see also Friendly, Mason Book Review, supra note 226 , at 426 (" $[\mathrm{H}] \mathrm{e}$ had no doubts once a decision had been made.").

237 Friendly, Bickel Book Review, supra note 208, at 767.

238 Friendly-Epsteins Interview, supra note 72, pt. V, side 1, at 5.

${ }^{239}$ Letter from Henry J. Friendly to Elliot Janeway (Oct. 7, 1983) (on file with Friendly Papers, supra note 72, Box 220, Folder 220-6) ("I like the way in which [Lewis] Paper shows the whole man, warts and all, and there were warts."). Judge Wyzanski wrote:

And yet I am tempted to ask whether your view of LDB was not to some extent colored by your idealistic hopes when you were just out of law school and by your sadness at finding his failure to meet the standards that seemed possible to one recently graduated? - Would you not have been equally disappointed had you been Lincoln's secretary or John Marshall's clerk?-To which you may properly answer "Were you disappointed in A.N. Hand or L.H.? ** Were H. Stimson's or R. Patterson's juniors disappointed? Were Cardozo's?"-And my reply must be that the company of the pure is very, very small and it excludes some of the truly great.

Letter from Charles E. Wyzanski to Henry J. Friendly (June 22, 1958) (on file with Friendly Papers, supra note 72, Box 235, Folder “Scrapbook 1959-"). 
School. By repeatedly rejecting Brandeis's entreaties to teach at Harvard or enter public service, Friendly was like the prodigal son.

\section{A. Friendly's Career Choices}

During the clerkship, Brandeis had refrained from discussing Friendly's career plans. Nor did Brandeis offer his standard advice to clerks to eschew big city law practice and return to their hometowns because Friendly's hometown, Elmira, New York, was "a little too small."240 Instead, Brandeis suggested Omaha, Nebraska. ${ }^{241}$ Brandeis knew where Friendly wanted to go- the Root, Clark firm in New York City. ${ }^{242}$ After Friendly had asked for an extra day over Christmas break to "look into N.Y. offices," Brandeis informed Frankfurter that "[t]here seems no chance of your getting Friendly [at Harvard]-next year at least."243 Frankfurter was "not surprised about Friendly."244

Brandeis worked on Friendly for the future, enlisting former clerk and Harvard law professor James Landis to write Friendly near the end of Friendly's clerkship. ${ }^{245}$ Landis already knew Friendly's plans. In April 1928, Friendly wrote Landis:

What you say about teaching makes me doubly glad that I've decided to get a taste of practice. I always had much the feeling that you seem to have

240 Paper-Friendly Interview, supra note 85 , at 3 ("When I was leaving he didn't talk to me about teaching, but he did talk to me about my future. He knew I was interested in going to New York because I had an offer there, but he didn't want me to go. He didn't like New York. So I said, 'Mr. Justice, should I go back to Elmira?,' which is where I'm from. 'Oh no,' he said, 'I think that [is] a little too small.' And I said, 'Well, no one else wants me.' And he said, 'Well, you're making a mistake.'”).

${ }^{241}$ Henry J. Friendly, Speech in Honor of Dave Peck 2-3 (undated) (on file with Friendly Papers, supra note 72, Box 227, Folder 227-16 "Reference Letters 1972-1983") ("One time when Mr. Justice Brandeis was attempting to persuade me not to go to New York as being too big but recognized that my hometown of Elmira was too small, he suggested of all places, Omaha. Somehow, with all respect to Dave and Justice Brandeis, one of the regrets I do not have is not having spen[t] my life in Omaha.").

242 Paper-Sutherland Interview, supra note 70, at 2 (Brandeis thought "the New York bar did not produce great lawyers. Their experiences were too parochial. He always said the attomeys from outside New York were better than the average New York lawyer.").

243 Letter from Louis D. Brandeis to Felix Frankfurter (Dec. 25, 1927), reprinted in HALF BROTHER, HALF SON 314 (Melvin I. Urofksy \& David W. Levy eds., 1991).

${ }^{244}$ Letter from Felix Frankfurter to Louis D. Brandeis 1 (Dec. 31, 1927) (on file with LDB-Louisville, supra note 120 , reel 49 , at 421).

245 Letter from Louis D. Brandeis to Felix Frankfurter (Aug. 20, 1928) (on file with FF-LC, supra note 34, Box 27, Folder "Brandeis, Louis D. 1928 \#38"), reprinted in 5 LETTERS OF LDB, supra note 58, at 354 ("Jim Landis should write H.J.F."). 
now; namely, that if it weren't for F.F., the Law School would be a pretty deadening place. What I wonder is whether it is wise to be so dependent on any single individual as I fear I'd become if I returned there. Sometimes I've thought seriously about the I.C.C. I've met one or two of the better examiners, and they seem to be highly competent men who have the joy of making important decisions. Of course, the pay is small, but if one gets fed up with it, a Railroad will generally pay more. However, I'm going dutifully to Root, Clark, and a year from now I'll be a wiser and, I hope, not a sadder man. 246

Friendly broke the news to Brandeis, who replied: "Well, you're making a mistake."247

Friendly's choice of private practice reflected the low regard for public service among the generation of law graduates sandwiched between World War I and the looming Great Depression, "[b]orn to an Era of Insecurity."248 Friendly recalled that among his 1927 Harvard classmates

practically everyone thought there was only one career that was worth pursuing, namely, private practice. There were a few who were lured into law teaching; there were others who went into government work, most of them, I think, because they didn't have quite the grades to get the jobs they wanted in private firms . . . 249

Friendly's grades, Harvard Law Review editorship, and Brandeis clerkship should have made him the first choice of any New York law firm. Anti-Semitism, however, circumscribed Friendly's options, especially in the late 1920s. ${ }^{250}$ "Why did I start at Root, Clark?" Friendly remarked. "[I]t was the only place in New York that a Jew could get a job." 251 It wasn't the only place, but it may have been the only prestigious place. Friendly chose Root, Clark because of the firm's Jewish partner Leo Gottlieb and Buckner's

246 Letter from Friendly to Landis (Apr. 7, 1928), supra note 168, at 2-3; cf. Michael Boudin, Madison Lecture: Judge Henry Friendly and the Mirror of Constitutional Law, 82 N.Y.U. L. REv. 975, 978 (2007) [hereinafter Boudin, Madison Lecture] (recalling Friendly said "law teaching was a lot less interesting in the 1920s: The common law subjects, he said, had been worked through, and the explosion of New Deal legislation, the rise of the agencies, and much else was hidden around the comer").

247 See Paper-Friendly Interview, supra note 85 , at 3.

248 Jerold S. Auerbach \& Eugene Bardach, "Born to an Era of Insecurity": Career Patterns of Law Review Editors, 1918-1941, 17 AM. J. LegAL HIST. 3, 3 (1973).

249 THE PATH OF THE LAW From 1967, at 114 (Arthur E. Sutherland ed., 1968).

250 Eli Wald, The Rise and Fall of the WASP and Jewish Law Firms, 60 STAN. L. REV. 1803, 1810-11 (2008) (explaining that, until 1945, large law firms in New York City were known as WASP, Jewish, or Catholic).

251 Gerald T. Dunne, Grenville Clark: Public Citizen 49 (1986). Leo Gottlieb replied: "Not true . . . but almost true." Id. 
mentoring. ${ }^{252}$ Buckner mocked religious stereotypes by comparing the cocky Episcopalian Page and the quiet Jewish Friendly and reversing their religious backgrounds: "Friendly with even a better record and quite as much or more to spoil him and has much better manners. But you see Bob is a jew, as you know and Friendly is a gentile, and, frankly, naturally, that makes a difference!!"253

Buckner sought Page and Friendly not because of their Brandeis clerkships but because Frankfurter had vetted them against other Harvard Law Review editors. ${ }^{254}$ Root, Clark and other top New York firms sought Harvard, Yale, and Columbia law review editors. ${ }^{255}$ Modern clerkships were so nascent an institution and clerks were so few in number that no market had developed for them as clerks.

Brandeis was disappointed that his last two clerks had joined the same firm. "The satisfaction I had in having Page and Friendly with me is a good deal mitigated by the thought of their present activities," he wrote Frankfurter. "Of course it is possible that they, or at least Friendly, may reform and leave his occupation." 256

\section{Root, Clark}

Friendly began at Root, Clark apprenticing with name partner Grenville Clark. A Harvard law-educated aristocrat, Clark had helped organize American troops before World War I. Upon returning to the firm, he worked so hard that in 1926 he suffered a nervous breakdown. ${ }^{257}$ Advised to slow down, he was supposed to rely on his new associate. 258 "Grenny has annexed

252 Friendly-Epsteins Interview, supra note 72, pt. VI, side 1, at 110.

253 Letter from Emory Buckner to Felix Frankfurter 2 (Nov. 25, 1928) (on file with FF-LC, supra note 34, Box 31, Folder "Buckner, Emory R. 1928-1929 \#25").

${ }^{254}$ Letter from Buckner to Frankfurter (Dec. 21, 1926), supra note 121, at 2 ("We would like to get Schwartz and Hall out of this year's class if they decide to come into a New York office....").

${ }^{255}$ Letter from Emory Buckner to Felix Frankfurter 1-2 (Feb. 26, 1926) (on file with FF-LC, supra note 34, Box 31, Folder "Buckner, Emory R. 1926") (hiring Yale Law Journal editor-in-chief, another Yale Law Journal editor, and two Harvard Law Review editors).

${ }^{256}$ Letter from Louis D. Brandeis to Felix Frankfurter 2 (Oct. 13, 1929) (on file with FF-LC, supra note 34, Box 27, Folder "Brandeis, Louis D. 1929 \#4,"), reprinted in 5 LETTERS OF LDB, supra note 58, at 404.

257 DUNNE, supra note 251, at 50.

258 Friendly-Epsteins Interview, supra note 72, pt. VI, side 1, at 107. 
Friendly and likes him very much," Buckner wrote Frankfurter. ${ }^{259}$ Friendly's exclusive apprenticeship with Clark was short-lived. After a few railroad rate cases, Friendly became bored because Clark was doing all the work. One day, Buckner spied Friendly doing a New York Times crossword puzzle in the office. Friendly said he liked Clark but needed more work. ${ }^{260}$

Buckner engaged Friendly by pairing him with future Supreme Court Justice John Marshall Harlan. Harlan had joined Root, Clark in 1927 after working with Buckner at the U.S. Attorney's office. Friendly helped Harlan represent the executors of the will of reclusive heiress Miss Ella von Echtzel Wendel, who had left most of her millions to charity. ${ }^{261}$ Friendly admired Harlan's sympathetic cross-examination questions that destroyed the stories of the estate's fraudulent claimants. "The lessons I learned from this 'veteran,' then with nine years of experience, would never be forgotten," Friendly wrote, "and the joy of our work together has constituted a lasting bond." 262

\section{Passing on Harvard}

After bonding with Harlan, Friendly declined several offers to teach at Harvard Law School. Brandeis and Frankfurter knew that Friendly would reconsider teaching after three years of practicing law. "I had been thinking last night of Friendly and his 3 year trial period now would be over soon," Brandeis wrote Frankfurter. "I hope [Friendly] would conclude to go to Harvard now."263 Anti-Semitism plagued Harvard Law School as badly as New York City law firms. One of Frankfurter's other protégés, Nathan Margold, was denied a tenure-track professorship after several years as an

${ }^{259}$ Letter from Emory Buckner to Felix Frankfurter 2 (Nov. 25, 1928) (on file with FF-LC, supra note 34, Box 31, Folder "Buckner, Emory R. 1928-1929 \#25"); LEO Gottlieb, Cleary, GotTlieb, STEen \& Hamilton 33 (1983).

${ }^{260}$ Friendly-Epsteins Interview, supra note 72, pt. VI, side 1, at 107-08; DUNNE, supra note 251 , at 27.

261 See ARTHUR GARFIELD HAYS, CITY LAWYERS 325 (1942).

262 Friendly, Mr. Justice Harlan, supra note 208, at 383-84; see also FriendlyEpsteins Interview, supra note 72, pt. VI, side 1, at 110; GoTTLIEB, supra note 259, at 33.

263 Letter from Louis D. Brandeis to Felix Frankfurter (May 2, 1931) (on file with FF-LC, supra note 34, Box 28, Folder "Brandeis, Louis D. 1931 \#56"). 
instructor. ${ }^{264}$ Friendly's sterling academic record, however, overcame any anti-Semitism when it came to a Harvard professorship. ${ }^{265}$

In April 1931, Harvard Law Dean Roscoe Pound met with Friendly and offered him an assistant professorship. ${ }^{266}$ Friendly asked Frankfurter about postponing the offer for a year or even ten to fifteen. ${ }^{267}$ Frankfurter wanted Friendly to accept immediately. "Such powers as you have call for their fulfillment as much as Kreisler's gifts call for playing the violin," he wrote Friendly. "That this life would give you scope and satisfaction I have not the slightest doubt."268 Frankfurter promised Friendly a full professorship within three years. ${ }^{269}$ Austin Wakeman Scott, Friendly's first-year civil procedure professor, traveled from Cambridge to New York City to recruit him. ${ }^{270}$

In May 1931, Friendly decided to stay at Root, Clark. 271 "I have not been able to convince myself that I am ready, once and for all, to renounce active practice in favor of the academic life," he wrote Pound. ${ }^{272}$ Friendly confided to Landis:

I don't ever think I've ever had a problem that caused such real anguish. ... The real basis for my decision was, I think, a feeling that Cambridge would be too pleasant. My life, as you know, has always been a pretty soft and easy one. It's only been since my coming to New York that I've had to battle people, to fight, sometimes to win and sometimes to lose. I think the

264 Letter from Louis D. Brandeis to Felix Frankfurter (Feb. 26, 1928), reprinted in HALF BROTHER, HALF SON, supra note 243, at 268 n.2, 323. Indeed, Frankfurter was the only Jewish professor at Harvard Law School for twenty-five years. JEROLD S. AUERBACH, RABBIS AND LAWYERS 155 (1990).

${ }^{265}$ Letter from Emory Buckner to Felix Frankfurter (Mar. 5, 1928) (on file with FFLC, supra note 34, Box 31, Folder "Buckner, Emory R. 1928-29 \#5") (comparing Margold's denial with faculty assertions that "Friendly could be appointed tomorrow"); Letter from Henry J. Friendly to Donald Robinson (Mar. 26, 1984) (on file with Friendly Papers, supra note 72, Box 221, Folder 221-1) (denying that Margold's problems or antiSemitism played any role in his decision whether to join the Harvard faculty).

266 Letter from Henry J. Friendly to Felix Frankfurter (Apr. 1931) (on file with FF-

LC, supra note 34, Box 56, Folder "Friendly, Henry J. 1927-1937 \#1").

267 Id.

${ }^{268}$ Letter from Felix Frankfurter to Henry J. Friendly (Apr. 30, 1931) (on file with FF-LC, supra note 34, Box 56, Folder "Friendly, Henry J. 1927-1937 \#1").

269 Id.

270 See Letter from Friendly to Robinson (Mar. 26, 1984), supra note 265; Letter from Austin Wakeman Scott to Henry J. Friendly (Sept. 27, 1974) (on file with Friendly Papers, supra note 72, Box 235, Folder "Scrapbook 1959-") (recalling Scott's recruitment efforts).

${ }^{271}$ Letter from Henry J. Friendly to Felix Frankfurter (May 7, 1931) (on file with FF-LC, supra note 34, Box 56, Folder "Friendly, Henry J. 1927-1937 \#1").

272 Letter from Henry J. Friendly to Roscoe Pound (May 6, 1931) (on file with FFLC, supra note 34, Box 56, Folder "Friendly, Henry J. 1927-1937 \#1"). 
experience has been a developing one and that I should be doing myself an injustice if I cut it too short. 273

Friendly "enjoyed practice" and "[a]s Felix is so fond of saying, one's going to live a long time; and I simply couldn't convince myself that the date to end the practice stage of my career had yet come."274

\section{No to Public Service}

A year after Friendly spurned Harvard, Brandeis and Frankfurter tried to engineer Friendly's return to Washington working for Eugene Meyer at the Reconstruction Finance Corporation (RFC). On February 13, 1932, Brandeis wrote Frankfurter: "Friendly was in. Of course I advised him to take the RFC job. Eugene was in yesterday \& I told him not to let Friendly get away from him. It is evident that the wise men of the firm are repeating what they did about the Harvard offer." 275 Brandeis was right. Grenville Clark, as well as Friendly's father-in-law, Horace Stern, a Pennsylvania court of common pleas judge, advised against it. ${ }^{276}$ Friendly informed Brandeis and Frankfurter that he had declined Meyer's offer. ${ }^{277}$ "Incidentally," he wrote Frankfurter, "you may be interested to know that when my father-in-law sounded out Judge Cardozo on the subject of my going down to Washington, his quick reaction was against it." 278

273 Letter from Henry J. Friendly to James Landis 1-2 (May 7, 1931) (on file with Landis Papers, supra note 38, Box 5, Folder "1925-1933 Friendly, Henry").

${ }^{274}$ Id. at 2; see also Letter from Henry J. Friendly to Roscoe Pound (Jan. 20, 1937) (on file with Roscoe Pound Papers, Harvard Law School, reel 75, at 85) (admitting after making partner that "I cannot honestly say that I have not regretted the decision that I made several years ago" [not to join the Harvard faculty]); Letter from Henry Friendly to Grenville Clark 1-2 (Feb. 6, 1939) (on file with Grenville Clark Papers, Dartmouth College, Rauner Library [hereinafter Clark Papers], Series 4-Harvard Corporation, Box 4) (declining "behest of certain members of the faculty" to return to teach at Harvard Law School and admitting having declined offers "on at least two occasions in the past").

275 Letter from Louis D. Brandeis to Felix Frankfurter (Feb. 13, 1932) (on file with FF-LC, supra note 34, Box 28, folder "Brandeis, Louis D. 1932 \#60"), reprinted in 5 LETTERS OF LDB, supra note 58, at 475.

${ }^{276}$ Friendly-Epsteins Interview, supra note 72 , pt. VIII, side 2, at 156. In 1936, Stern became a Pennsylvania Supreme Court justice and in 1952 its chief justice. See Historical List of Supreme Court Justices, THE UNIFIED JUDICIAL SYSTEM OF PENNSYLVANIA, http://www.aopc.org/T/SupremeCourt/SCJustices.htm.

${ }^{277}$ Letter from Henry J. Friendly to Felix Frankfurter (Feb. 16, 1932) (on file with FF-LC, supra note 34, Box 56, Folder "Friendly, Henry J. 1927-1937 \#1"); Letter from Henry J. Friendly to Louis D. Brandeis (Feb. 16, 1932) (on file with LDB-Louisville, supra note 120 , reel 50 , at 62 ).

${ }^{278}$ Letter from Friendly to Frankfurter (Feb. 16, 1932), supra note 277, at 2. 
Frankfurter and Brandeis blamed Friendly for listening to the wrong people. 279 "As to the New York advice that you had, I can only say that I expect you to be wiser than most of the men whom you consult," Frankfurter wrote Friendly. "I wonder if you think any of them are wiser than L.D.B. . . As for Cardozo's views on the matter-I should like to argue the case before him and see what his reaction would be." 280 Brandeis wrote Frankfurter that Friendly's decision

discloses his Achilles heel. He stated to me that before Eugene had summoned him, he had been "dreaming" whether by some happy chance he might not get the job-and was eager to come, showing more emotion than he had ever disclosed here. I fancy his superiors are not much given to patriotic endeavors. ${ }^{281}$

Friendly said he had declined because the RFC was "a sinking ship" in the final days of a lame-duck Hoover Administration. ${ }^{282}$ But he later admitted to Frankfurter that turning down the RFC had been a mistake. ${ }^{283}$

The RFC job was the type of position for which Brandeis and Frankfurter had been grooming their young legal elites. After Friendly declined, former Holmes clerk Tommy Corcoran took the RFC job and wielded considerable power during Roosevelt's New Deal along with fellow Frankfurter/Brandeis protégés Benjamin Cohen and Landis. ${ }^{284}$ Landis visited Brandeis and talked of combining his professorship with working in Washington, obliterating Friendly's false dichotomy between law teaching and active lawyering. "Friendly must have regretted many times his decision not to come here," Brandeis wrote Frankfurter after seeing Landis. ${ }^{285}$ Friendly knew that

${ }^{279}$ Letter from Felix Frankfurter to Henry J. Friendly (Feb. 17, 1932) (on file with FF-LC, supra note 34, Box 56, Folder "Friendly, Henry J. 1927-1937 \#1") ("deeply disappointed"); Friendly-Epsteins Interview, supra note 72, pt. VIII, side 2, at 156 ("And Felix was really annoyed at that, I think. ... [H]ere he thought was a real opportunity for public service, and that I had turned my back on it for filthy lucre, and so forth.").

280 Letter from Frankfurter to Friendly (Feb. 17, 1932), supra note 279.

${ }^{281}$ Letter from Louis D. Brandeis to Felix Frankfurter (Feb. 19, 1932) (on file with FF-LC, supra note 34, Box 28, Folder "Brandeis, Louis D. 1932 \#60").

282 Paper-Friendly Interview, supra note 85 , at 5 .

${ }^{283}$ Letter from Henry J. Friendly to Felix Frankfurter (Mar. 14, 1959) (on file with Friendly Papers, supra note 72, Box 191, Folder 191-13) ("when I had the bad judgment to decline Eugene Meyer's offer in 1932").

284 See Peter H. IRONS, THE New Deal Lawyers (1982); William E. Leuchtenburg, Franklin D. Roosevelt and the New Deal, 1932-1940 (1963); THOMAS K. MCCRAW, PROPHETS OF REGULATION ch. 5 (1984); DAVID MCKEAN, TOMMY THE CORK (2004).

285 Letter from Louis D. Brandeis to Felix Frankfurter (Sept. 15, 1933) (on file with FF-LC, supra note 34, Box 28, Folder "Brandeis, Louis D. 1933 \#68"). 
Frankfurter and Brandeis were "a little sore at [him]."286 Friendly had rejected the Brandeis clerkship's second goal, public service.

\section{Court-Packing}

Friendly's rift with Frankfurter grew over Roosevelt's court-packing plan. Friendly spoke out against it and felt that Frankfurter should have too. ${ }^{287}$ Frankfurter, however, remained publicly silent but privately supported Roosevelt. ${ }^{288}$ From 1937 to 1953 , there is no surviving Friendly-Frankfurter correspondence. 289

Roosevelt's February 5, 1937, court-packing announcement briefly brought Friendly closer to Brandeis. Ten days later, Friendly debated Yale Law School Dean Charles Clark and attacked the plan as "one of the most serious threats to our liberty that our generation has seen."290 Friendly was introduced as a Root, Clark lawyer and former Brandeis clerk. During the debate, Friendly quoted a comment that Brandeis had made in 1928 about the Court shifting from "reactionary" to "liberal" every few years as a reason not to add Justices to the Court. The next day, the anti-Roosevelt New York Sun ran a small story headlined: "Brandeis Quoted on Court's Trend: Justice Predicted a Liberal Bench, ex-Aid [sic] Says."291 Friendly was embarrassed by the article and wrote Brandeis an apology. Brandeis responded: "Don't let the incident give you concern."292 Brandeis facilitated and signed Chief Justice Hughes's letter, which rebutted Roosevelt's allegations that the Justices were too old to maintain their workload and struck the first blow to

286 Paper-Friendly Interview, supra note 85, at 5.

${ }^{287}$ Letter from Willard Hurst to Gerald T. Dunne, (Aug. 26, 1980) (on file with Hurst Papers, University of Wisconsin Law School, Box 14, Folder 114) ("[Frankfurter's] overt support of the packing plan would have raised an extremely difficult point for him in his long relation to the Justice."); Friendly-Epsteins Interview, supra note 72, pt. VIII, side 2, at 156 ("I never put it to him, really. . . I'm awfully glad I didn't know it at the time- that far from opposing it, he'd been writing Roosevelt privately that he favored it.").

${ }^{288}$ Letter from Franklin D. Roosevelt to Felix Frankfurter (Feb. 9, 1937), in ROOSEVELT AND FRANKFURTER: THEIR CORRESPONDENCE 1928-1945, at 381-82 (Max Freedman ed., 1967); JEFF SHESOL, SUPREME POWER 332-35 (2010).

289 See FF-LC, supra note 34, Box 56.

290 Dean Clark, Friendly, in Court Debate, HARTFORd CouranT, Feb. 16, 1937, at 20.

291 Brandeis Quoted on Court's Trend, N.Y. SUN, Feb. 16, 1937, at 19.

${ }^{292}$ Letter from Louis D. Brandeis to Henry J. Friendly (Apr. 1, 1937) (on file with Urofsky Papers, supra note 125, Box 12, Folder 15), reprinted in 5 LETTERS OF LDB, supra note 58, at 587-88; Letter from Henry J. Friendly to Melvin Urofsky and David Levy 2 (June 14, 1967) (on file with Friendly Papers, supra note 72, Box 217, Folder 217-5); Paper-Friendly Interview, supra note 85, at 5. 
the court-packing plan. ${ }^{293}$ The New York Sun article showed that Brandeis had increased the currency of clerkships and that Friendly would be forever identified as a Brandeis clerk.

\section{Cleary, Gottlieb, and Pan Am}

After ten years at Root, Clark, Friendly made partner on January 1, $1937^{294}$ and was far from Brandeis and Frankfurter's academic and public service aspirations. Friendly's correspondence with Brandeis was sparse because Brandeis corresponded more with his clerks in academia. ${ }^{295}$ Frankfurter's last surviving correspondence with Friendly of more than a dozen years acknowledged Friendly's Christmas card and new title. "You know what a queer codger I am, and how little I care about worldly hierarchical distinctions," Frankfurter wrote. "But you also know how deeply I care that the fullest opportunity for professional excellence and social usefulness should come to men gifted as highly as you are."296

During the rise of big law firms and the regulatory state, Friendly excelled as a top New York regulatory litigator and corporate counsel. Early in his career, he represented a fledgling airline company in Pan American Airways, helped draft the Civil Aeronautics Act, and defended the company before the Civil Aeronautics Board. ${ }^{297} \mathrm{He}$ also headed off Senator Hugo Black's investigation of the company's domestic and foreign airmail contracts with the U.S. Postal Service. ${ }^{298}$ In addition to Pan Am, he represented Paramount Pictures and New York Telephone.

On January 1, 1946, Friendly and several Root, Clark lawyers left in a leadership dispute and started Cleary, Gottlieb, Friendly \& Cox. ${ }^{299}$ Friendly

293 SHESOL, supra note 288, at 393-400; Richard D. Friedman, Chief Justice Hughes' Letter on Court-Packing, 1997 J. SUP. CT. HIST. 76, 81; William E. Leuchtenburg, The Nine Justices Respond to the 1937 Crisis, 1997 J. SUP. CT. HIST. 55, 62-64.

294 GOTTLIEB, supra note 259 , at 33-34.

${ }^{295}$ Landis COH, supra note 64 , at 70-71 (suggesting Brandeis was closer to clerks in academia).

296 Letter from Felix Frankfurter to Henry J. Friendly (Feb. 23, 1937) (on file with FF-LC, supra note 34, Box 56, Folder "Friendly, Henry J. 1927-1937 \#1").

${ }^{297}$ Friendly-Epsteins Interview, supra note 72, pt. VI, side 1, at 109-12; The Reminiscences of Judge Henry J. Friendly, at 17-19 (1960) (on file with Aviation Project, Oral History Research Office, Butler Library, Columbia University, New York, 1967).

298 Friendly-Epsteins Interview, supra note 72, pt. VI, side 1, at 112.

299 GOTTLIEB, supra note 259, at 2. On firm's founding, see id. at 53-60; see also Friendly-Epsteins Interview, supra note 72, pt. VIII, side 2, at 160; Letter from Henry Friendly to Grenville Clark 1-2 (Nov. 1, 1945) (on file with Clark Papers, supra note 
took his big clients with him. He doubled as Pan Am general counsel/vice president and Cleary partner. ${ }^{300}$ Friendly's Pan Am work helped the firm land other major clients in the airline industry. ${ }^{301}$ And his productivity level on non-Pan Am matters "would have compared favorably with the full-time efforts of any ordinary lawyer." 302 But the workload was too much.

\section{Calling on the Second Circuit}

Friendly may not have followed Brandeis's preferred career path, but, like Brandeis, he looked to the bench after a lifetime of private practice. Tired of his "double life" as a Pan Am executive and Cleary partner, Friendly inquired in the early 1950 s about a Second Circuit judgeship. ${ }^{303} \mathrm{He}$ asked Leo Gottlieb to contact Attomey General Herbert Brownell, who was encouraging but reported that U.S. Attorneys Edward Lumbard and Leonard Moore had been promised Second Circuit nominations. ${ }^{304}$

Friendly contacted lawyers and politicians to promote him for the Second Circuit, including his erstwhile mentor, now Justice, Felix Frankfurter. With former Root, Clark partner John Harlan's nomination to the Supreme Court in November 1954, Friendly congratulated Frankfurter on his "new colleague" and confided that he coveted Harlan's Second Circuit seat. ${ }^{305}$ "I am sure this is something I could do well;" Friendly wrote Frankfurter, "it is the only judicial post, what of course of Olympus, which would attract me; and I have a feeling that for a Republican [like me] a chance like this may not recur."306 A nominal Republican, Friendly was not active, did not know New York's lone Republican U.S. Senator Irving Ives, and inquired about Frankfurter's Republican connections. 307 "I would rejoice to have you a member of that Court," Frankfurter replied. "You would be worthy of the great line. Naturally I want to do what lies within my power to further that

272, Series 26-Law Firm, Box 1) (describing impending split at Root, Clark and concluding: "Whatever doubts I may have had before taking [sic] the decision, I have had none since.").

300 GOTTLIEB, supra note 259, at 125; see also Friendly-Epsteins Interview, supra note 72 , pt. VIII, side 2 , at 160 .

301 See GoTTLIEB, supra note 259 , at 83.

302 Id. at 125 .

${ }^{303}$ Friendly-Epsteins Interview, supra note 72, pt. VIII, side 2, at 157.

304 Id. at $157-58$.

305 Letter from Henry J. Friendly to Felix Frankfurter 1 (Nov. 10, 1954) (on file with FF-LC, supra note 34, Box 56, Folder "Friendly, Henry J. 1953-1955 \#2").

306 Id. at 2.

${ }^{307} \mathrm{Id}$. at $2-3$. 
consummation. I can say no more at the moment than that I shall think how I can do what I should like to do." 308

In 1954, Frankfurter was unwilling to lobby the President or Attorney General, ${ }^{309}$ but enlisted Second Circuit Judge Learned Hand. ${ }^{310}$ Hand agreed to help: "I am only just acquainted with Friendly, so that I have not the faintest personal interest in him. It is merely that an old dog would like to see the kennel filled with the right sort of pup."311 Frankfurter sent a letter from Hand to Senator Ives. As Friendly suspected, he did not get the job. ${ }^{312}$

When Jerome Frank's death in 1957 created another vacancy, Frankfurter and Hand again promoted Friendly. They feared the promotion of Irving Kaufman as a reward for trying atomic spies Julius and Ethel Rosenberg and sentencing them to death. ${ }^{313}$ Frankfurter broke his vow not to lobby the Executive Branch and wrote an impassioned letter to Brownell. ${ }^{314}$ Neither Friendly nor Kaufman got the job; as Brownell had predicted, Lumbard and Moore received the first two vacancies.

The following year, Harold Medina's retirement renewed Hand and Frankfurter's quest to promote Friendly over Kaufman. On January 22, 1959, Hand circumvented Brownell and wrote to President Eisenhower. ${ }^{315}$ It was only the second time Hand had written the President about a judicial appointment. ${ }^{316}$ Although the New York Times proclaimed Friendly the favorite, ${ }^{317}$ Sen. Jacob Javits (R-N.Y.), like Brownell, seemed to favor

${ }^{308}$ Letter from Felix Frankfurter to Henry J. Friendly 1 (Nov. 13, 1954) (on file with Friendly Papers, supra note 72, Box 235, Folder "Scrapbook 1954-1959").

${ }^{309}$ Letter from Felix Frankfurter to Learned Hand 1 (Jan. 4, 1955) (on file with Friendly Papers, supra note 72, Box 235, Folder "Scrapbook 1954-1959"); Hand Papers, supra note 57, Box 105C, Folder 105C-20).

310 See GUNTHER, supra note 57, at 647-48.

311 Letter from Leamed Hand to Felix Frankfurter (Dec. 30, 1954) (on file with Friendly Papers, supra note 72, Box 235, Folder "Scrapbook 1954-1959") (typescript on file with FF-LC, supra note 34, Box 65, Folder "Learned Hand 1954").

312 Letter from Learned Hand to Henry J. Friendly (Jan. 10, 1955) (on file with Friendly Papers, supra note 72, Box 235, Folder "Scrapbook 1954-1959").

313 GUNTHER, supra note 57, at 648-50; Brad Snyder, Taking Great Cases: Lessons from the Rosenberg Case, 63 VAND. L. REv. 885, 896 n.40 (2010) (noting Kaufman's ex parte communications with Justice Department).

314 Letter from Felix Frankfurter to Attorney General Herbert Brownell (Jan. 28, 1958) (on file with Hand Papers, supra note 57, Box 105D, Folder 105-23).

315 Letter from Learned Hand to President Dwight D. Eisenhower (Jan. 22, 1959) (on file with Hand Papers, supra note 57, Box 87, Folder 87-33); Judge Hand Endorses Airline Aide for Bench, N.Y. TIMES, Feb. 17, 1959, at 34.

316 Letter from Learned Hand to President Dwight D. Eisenhower (Oct. 22, 1954) (on file with Hand Papers, supra note 57, Box 87, Folder 87-33) (endorsing Harlan's Supreme Court nomination).

317 City Lawyer Gets Backing as Judge, N.Y. TIMES, Jan. 16, 1959, at 25. 
Kaufman. 318 Hand believed Friendly "has as much chance as I have of being Grand Lhama of Tibet." 319 William P. Rogers, however, replaced Brownell as Attorney General Frankfurter wrote Rogers, ${ }^{320}$ and Rogers recommended Friendly. 321

On March 10, 1959, Eisenhower nominated the 55-year-old Friendly. Hand and Frankfurter rejoiced. ${ }^{322}$ The New York Times and Washington Post praised Friendly's nomination. ${ }^{323}$ The Times profile, "From Clerk to Judge," led with Brandeis's comment to Frankfurter not to send him more clerks like Friendly. ${ }^{324}$ The Times story not only identified Friendly with Brandeis but also linked Friendly's clerkship to his judgeship.

In responses to congratulatory letters, Friendly acknowledged Brandeis's influence on his career choice and perpetuated the ideal vision of his judge. Friendly wrote Harvard classmate and Holmes clerk John Lockwood: "The possibility of resuming the sort of activities we pursued together in Law School and which I had with Brandeis in the following year has been a very powerful motivation." 325 Former girlfriend Catherine Kou recalled "a day long long ago when you told me that you were ambitious for only one thing to serve eventually on the Supreme Court. Isn't that the next step?"326 Brandeis's daughter, Susan, wrote: "Father would have been pleased indeed, in view of the high opinion he had of you, reflected in his observation to F.F[.], regarding your industry and powers of application as published in to-

318 Id.; Edward Ranzal, Politics Strains Courts, N.Y. TIMES, Feb. 8, 1959, at 76.

${ }^{319}$ Letter from Learned Hand to Felix Frankfurter (Jan. 19, 1958) (on file with Hand Papers, supra note 57, Box 105D, Folder 105D-23).

${ }^{320}$ Letter from Felix Frankfurter to William P. Rogers (Jan. 28, 1958) (on file with Hand Papers, supra note 57, Box 105D, Folder 105D-23).

321 Gillespie Named as U.S. Attorney, N.Y. TIMES, Mar. 6, 1959, at 51 (listing Friendly as "the likely choice").

322 Letter from Felix Frankfurter to Henry J. Friendly (Mar. 10, 1959) (on file with Friendly Papers, supra note 72, Box 235, Folder "Scrapbook 1954-1959"); Letter from Learned Hand to Henry J. Friendly (Mar. 17, 1959) (on file with Friendly Papers, supra note 72, Box 235, Folder "Scrapbook 1954-1959"); Letter from Learned Hand to Felix Frankfurter (Mar. 21, 1959) (on file with FF-LC, supra note 34, Box 65, Folder "Hand, Learned 1959").

${ }^{323}$ Editorial, Mr. Friendly for the Bench, N.Y. TiMES, Mar. 11, 1959, at 34; Editorial, Job Sought the Man, WASH. POST, Mar. 13, 1959, at A18.

324 From Clerk to Judge, N.Y. TimES, Mar. 11, 1959, at 38.

325 Letter from Henry J. Friendly to John Lockwood (Apr. 29, 1959) (on file with Friendly Papers, supra note 72, Box 191, Folder 191-13).

326 Letter from Katharine Kou to Henry J. Friendly (Mar. 13, 1959) (on file with Friendly Papers, supra note 72, Box 235, Folder "Scrapbook 1954-1959"). On their relationship, see Friendly-Epsteins Interview, supra note 72, pt. VI, side 2, at 120. 
day's Times. You now join [Brandeis clerk and First Circuit Judge] Calvert Magruder! We wish you an early confirmation." 327

Friendly's confirmation stalled because of lingering support for Kaufman and tepid support for Friendly among Javits, Kenneth Keating, and other senators. ${ }^{328}$ On July 2, 1959, columnist Drew Pearson predicted that Frankfurter would retire as soon as Friendly was confirmed and accused Frankfurter, who had suffered a heart attack the previous winter, of grooming Friendly as his replacement. ${ }^{329}$ Pearson's column exasperated Friendly, who urged Frankfurter to stay on the Court "as long as Holmes"; Friendly wanted no publicity except "a one line entry in the Congressional Record" indicating his confirmation. ${ }^{330}$

By mid-August, Friendly had not received a committee hearing because Senate Majority Leader Lyndon Johnson disliked Eisenhower's judicial nominee in the Eastern District of Texas. After the Texas nominee withdrew, Friendly received his hearing. ${ }^{331}$ On the Senate floor, Thomas Dodd questioned Friendly's lack of judicial experience vis-à-vis Kaufman. ${ }^{332}$ With Friendly's confirmation in jeopardy, Hand drafted and redrafted a letter that Frankfurter showed to Johnson. 333 "Your letter done it!" Frankfurter wrote Hand on August 19. "Senator Lyndon Johnson just phoned me that he has 'seen the gentleman,' one Dodd of Connecticut, and 'all will be O.K." 334 On September 9, 1959, six months after his nomination, Friendly was confirmed.

${ }^{327}$ Letter from Susan Brandeis to Henry J. Friendly (Mar. 11, 1959) (on file with Friendly Papers, supra note 72, Box 234, Folder "Scrapbook 1954-1959").

328105 CONG. REC. 10465-66 (1959) (including Friendly's telegram); Jacob Javits, Letter to the Editor, Support for Friendly, WASH. POST, June 14, 1959, at E4 (supporting Friendly); Editorial, Inexcusable Delay, WASH. POST, June 9, 1959, at A14 (criticizing Javits).

${ }^{329}$ Drew Pearson, The Washington Merry-Go-Round, July 2, 1959 (on file with Drew Pearson's Washington Merry-Go-Round, American University Library-Special Collections, Box 16, Folder 1); DrEW PEARSON: DiARIES 1949-1959, at 544 (Tyler Abell ed., 1974).

330 Letter from Henry J. Friendly to Felix Frankfurter (July 2, 1959) (on file with FF-LC, supra note 34, Box 56, Folder "Friendly, Henry J. 1956-58 \#3").

331 Anthony Lewis, Senate Unit Set to Act on Judges, N.Y. Times, Aug. 22, 1959, at 38; Hearing Set on Court Nominee, N.Y. TIMES, Aug. 19, 1959, at 14; Nominee's Withdrawal May End Senate Logjam, WASH. POST, Aug. 5, 1959, at A10.

332105 CONG. REC. 18673-74 (1959).

${ }^{333}$ Letter from Learned Hand to Felix Frankfurter (Aug. 10, 1959) (on file with Hand Papers, supra note 57, Box 105D, Folder 105D-25).

334 Letter from Felix Frankfurter to Learned Hand (Aug. 19, 1959) (on file with Hand Papers, supra note 57, Box 105D, Folder 105D-25); see Letter from Learned Hand to Felix Frankfurter 2 (Aug. 10, 1959) (on file with FF-LC, supra note 34, Box 65, Folder "Hand, Learned 1959") ("If you could find it within the proprieties to lend a hand in urging his confirmation, I am sure that you will be willing to do so, for I know that you 
Fulfilling Brandeis and Frankfurter's dreams of public service, Friendly admitted to Frankfurter: "Looking back on my own career, I can see that I stayed much too long in private practice-as, of course, you told me."335 Friendly confessed that he was "mightily scared" about joining the bench but that "you may be sure that the standard which I learned from you and L.D.B. thirty years ago will be my goal." 336 Frankfurter replied:

May you derive as much satisfaction from your judicial life as I am confident you will afford. I welcome you to the federal judiciary and rejoice, as I have no doubt L.D.B. would, that you have joined the historic procession of those who have given eminence to the Second Circuit. ${ }^{337}$

\section{B. Jurisprudence}

With his Second Circuit confirmation eighteen years after Brandeis's death, Friendly was one of many former clerks who contributed to the idealization and canonization of Brandeis. ${ }^{338}$ By adopting many professional lessons he learned from Brandeis, Friendly soon earned the reputation among other judges as the most revered federal appellate judge of his generation and Hand's intellectual heir on the Second Circuit. ${ }^{339}$ Brandeis influenced

share my ardor."); Friendly-Epsteins Interview, supra note 72 , pt. VIII, side 2, at 3 (acknowledging Frankfurter "had a lot to do with clearing up a little obstacle that had arisen to my confirmation"); PEARSON, supra note 329, at 544 (claiming Dodd wanted Catholic Connecticut judge Joe Smith nominated to Second Circuit). Johnson mentioned "numerous representations concerning Judge Friendly" and told the Senate "I hope he will be unanimously confirmed." 105 CONG. REC. 18673 (1959). Friendly was confirmed that day.

335 Letter from Henry J. Friendly to Felix Frankfurter (Aug. 12, 1963) (on file with FF-LC, supra note 34, Box 57, Folder "Friendly, Henry J. 1963-1964 \& undated \#7").

${ }^{336}$ Letter from Henry J. Friendly to Felix Frankfurter 3-4 (Sept. 10, 1959) (on file with FF-LC, supra note 34, Box 56, Folder "Friendly, Henry J. 1959 \#4").

${ }^{337}$ Letter from Felix Frankfurter to Henry J. Friendly (Sept. 29, 1959) (on file with Friendly Papers, supra note 72, Box 234, Folder "Scrapbook 1959-present").

338 G. Edward White, The Canonization of Holmes and Brandeis: Epistemology and Judicial Reputations, 70 N.Y.U. L. REV. 576, 609 n.184 (1995).

${ }^{339}$ Finley v. United States, 490 U.S. 545, 565 (1988) (Stevens, J., dissenting) ("universally recognized . . . as one of our wisest judges"); Extraordinary Session of the Court of Appeals for the Second Circuit, In Memoriam: Honorable Henry J. Friendly [hereinafter In Memoriam], 805 F.2d at LXXXVII (1986) (reprinting Thurgood Marshall's tribute to Friendly); Letter from Learned Hand to Felix Frankfurter (Mar. 26, 1960) (on file with FF-LC, supra note 34, Box 65, Folder "Hand, Learned 1960-61 \#41") ("Friendly is realizing all our hopes, especially inspired. He's a lightening calculator."); Letter from Charles E. Wyzanski to Henry J. Friendly (Nov. 18, 1961) (on file with Friendly Papers, supra note 72, Box 235, Folder "Scrapbook 1959-") ("You do write the best opinions of any (repeat "any") sitting judge!!"); Letter from Felix Frankfurter to 
Friendly's ultimate career choice, jurisprudence, professionalism, scholarship, and clerkship model.

Brandeis inspired Friendly's judicial career. Friendly viewed judging as a calling into a sacred order established by Holmes, Brandeis, Hand, and Cardozo. ${ }^{340}$ Friendly believed that he had lived through a golden era of American law that began in the 1870s with Langdell, Thayer, and Ames at Harvard Law School and ended in 1938 around Cardozo's death. Holmes had retired in 1932, Brandeis in 1939; only Hand kept judging. After reciting the era's great cases, Friendly wrote in 1961: "Against the galaxy of these and many other decisions, what of like importance have recent years of Supreme Court decisions offered, with the solitary exception of Brown v. Board of Education? . . Great creative eras cannot be expected to last forever."341

Jurisprudentially, Friendly continued the Brandeis tradition of deference to political branches and belief in a limited judicial role: "Solutions for most of these [problems of modern law] will call for action by elected legislators rather than judges; indeed, many will require handling upon supra-national lines." 342 Friendly and Brandeis were "jurisdiction hounds" 343 who avoided constitutional questions. They were reluctant to invalidate state or federal statutes on equal protection or due process grounds. They were pragmatists

Henry J. Friendly (Aug. 16, 1963) (on file with FF-LC, supra note 34, Box 56, Folder "Friendly, Henry J. 1963-64 \& undated \#7") ("But then it's no news to you that I regard you as the best judge now writing opinions on the American scene."); Carl McGowan, The Judges' Judge, 133 U. PA. L. REv. 34, 34 (1984) ('the lawyers' lawyer, the judges' judge, and the scholars' scholar"); Louis H. Pollak, In Praise of Friendly, 133 U. PA. L. REV. 39, 39 (1984) ("[L]ike Learned Hand before him-[Friendly] has exercised more decisive influence on the development of American law than any other contemporary federal judge, save only certain of the Justices of the Supreme Court."); Richard A. Posner, In Memoriam, 99 HARV. L. REV. 1709, 1724 (1986) ("most learned judge of his generation" and "greatest federal appellate judge of his time-in analytic power, memory, and application perhaps of any time"); John Minor Wisdom, Views of a Friendly Observer, 133 U. PA. L. REV. 63, 63-64 (1984) ("Within my lifetime, except for the giants (Holmes, Brandeis, and Cardozo) and possibly Learned Hand, no federal appellate judge has commanded more respect for his opinions and his writings than Henry Friendly."); Jon O. Newman, Letter to the Editor, From Learned Hand to Henry Friendly, N.Y. TIMES, Mar. 24, 1986, at A18 (describing Friendly as Hand's successor).

340 Judge Edward Weinfeld said the non-religious Friendly "took great pride in his calling. He approached his judicial task with a devotion akin to religious fervor. Indeed, one may say that his scholarly and painstaking effort to promote the cause of justice was his true religious faith." In Memoriam, 805 F.2d at XCII (1986).

341 Friendly, Reactions of a Lawyer, supra note 208, at 235-37.

342 Id. at 238.

343 Letter from Henry J. Friendly to Richard Posner (Jan. 30, 1984) (on file with Friendly Papers, supra note 72, Box 221, Folder 221-7) ("You have become a real jurisdiction hound-three cases, all dismissed for want of jurisdiction! Justice Brandeis would have been proud of you."). 
who spent their entire careers in private practice, Friendly until he was fiftyfive and Brandeis until he was sixty, which helped them understand how the law really worked.

Professionally, Brandeis taught Friendly about opinion-writing. Friendly and Brandeis wrote their opinions longhand. ${ }^{344}$ They excelled as judicial technicians who treated tedious cases with similar or more care than ones likely to grab headlines. And, like Brandeis, ${ }^{345}$ Friendly did not write in judicial sound bites. ${ }^{346}$ Their opinions were not quotable because they were so relentless. Friendly admired the rigor of Brandeis's opinions and applied the same standard to his own:

[T] he decider should cerebrate rather than emote about what he is deciding; that he should endeavor to provide a principle that can be applied not simply to the parties before him but to all having similar problems; that he should tell what he is doing in language that can be understood rather than indulge in flights of rhetoric; and that if he finds a principle is not working properly, he should qualify or overrule it candidly and openly rather than continue to profess adherence while reaching inexplicable results... [T] he momentary pleasure of reaching a "just" but unprincipled result in one case will not compensate for the agony of having to explain how he comes to a different conclusion in the next. ${ }^{347}$

Friendly wrote the leading Second Circuit opinions on administrative law, 348 criminal law, ${ }^{349}$ federal jurisdiction, ${ }^{350}$ railroad law, ${ }^{351}$ securities law, ${ }^{352}$ and trademark law. ${ }^{353}$

344 Friendly-Epsteins Interview, supra note 72, pt. V, side 1, at 8.

345 Freund, Centennial Memoir, supra note 65, at 783 ("To quote from Brandeis' opinions is, as Mr. Justice Frankfurter has remarked, to pull threads from a pattern, while to quote from Holmes is to string pearls."); cf. Felix Frankfurter, Mr. Justice Holmes and the Constitution, 41 HARV. L. REV. 121, 146 (1927) ("To consider Mr. Justice Holmes' opinions is to string pearls.").

346 Boudin, Madison Lecture, supra note 246, at 980 ("Although without the poetic magic of Holmes or the King James resonances of Hand or Jackson, Friendly had a command of metaphor, a stock of literary and operatic references, a deft use of sarcasm, and a crisp way of summing up a matter."); Pierre N. Leval, Judicial Opinions as Literature, in LAW's STORIES 209 (Peter Brooks \& Paul Gewirtz eds., 1996) (describing Friendly as "[n]ot a quotable judge. Not a maker of aphorisms.").

${ }^{347}$ HENRY J. FRIENDLY, BENCHMARKS, at viii (1967) [hereinafter FRIENDLY, BENCHMARKS].

348 Nat'l Nutritional Foods Ass'n v. FDA, 491 F.2d 1141 (2d Cir. 1974); Toilet Goods Ass'n v. Gardner, 360 F.2d 677 (2d Cir. 1966).

349 United States v. Geaney, 417 F.2d 1116 (2d Cir. 1969); United States v. Borelli, 336 F.2d 376 (2d Cir. 1964).

350 T.B. Harms Co. v. Eliscu, 339 F.2d 823 (2d Cir. 1964); HENRY J. FRIENDLY, FEDERAL JURISDICTION: A GENERAL VIEW (1973). 
Friendly and Brandeis were not jurisprudential clones. Friendly was more dispassionate; Brandeis was more cause-oriented. Friendly wanted to get it right; Brandeis wanted to get it right, but he also wanted to promote his pet issues. Sometimes, such as in Willing and Erie, Brandeis tackled issues not addressed in the briefs or at oral argument and seemed results-oriented. Brandeis judged like an advocate; Friendly transitioned from advocate to judge. Brandeis wrote landmark majority opinions and dissents that changed the course of American law; Friendly was a judicial incrementalist who believed that "precedent was a constant as central as any." 354 Friendly adhered to stare decisis and waited for the Supreme Court to overrule its outmoded precedents. ${ }^{355}$

Friendly was more willing to change his mind about the merits of a case than Brandeis. Friendly never agonized over the decision-making process like Learned Hand, but Friendly sometimes changed his mind because of another judge's voting memorandum or a conversation with a law clerk.

Friendly wrote fewer opinions about constitutional law than Brandeis because Friendly spent his entire career on the Second Circuit. The next Republican president, Richard Nixon, passed over Friendly in replacing Earl Warren. In late November 1968, Friendly attracted national attention for his speech criticizing the Court for stretching the Fifth Amendment's selfincrimination clause beyond its bounds and calling for a constitutional amendment to rectify the problem. ${ }^{356}$ Several judges, including Justice Harlan, favored Friendly. ${ }^{357}$ At age 65, Friendly was considered too old. And

${ }^{351}$ In re Valuation Proceedings Under $\S \S 303(\mathrm{c})$ and 306 of the Reg'l Rail Reorganization Act of 1973, 531 F. Supp. 1191 (Reg'l Rail Reorganization Ct. 1981).

352 Goldberg v. Meridor, 567 F.2d 209 (2d Cir. 1977); Gerstle v. Gamble-Skogmo, Inc., 478 F.2d 1281 (2d Cir. 1973).

353 Polaroid Corp. v. Polarad Elec. Corp., 287 F.2d 492 (2d Cir. 1961).

354 Boudin, Madison Lecture, supra note 246, at 982. See generally Henry J. Friendly, In Praise of Erie-And Federal Common Law, 39 N.Y.U. L. REV. 383 (1964); Frank I. Goodman, Judge Friendly's Contributions to Securities Law and Criminal Procedure: "Moderation is All," 133 U. PA. L. REV. 10 (1984).

355 See Square D Co. v. Niagara Frontier Tariff Bureau, Inc., 760 F.2d 1347, 1354 56 (2d Cir. 1985); Felton v. Sec'y, U.S. Dep't of Educ., 739 F.2d 48, 72 n.25 (2d Cir. 1984); Salerno v. Am. League of Prof'l Baseball Clubs, 429 F.2d 1003, 1005 (2d Cir. 1970).

356 Henry J. Friendly, The Fifth Amendment Tomorrow: The Case for Constitutional Change, 37 U. CIN. L. REV. 671 (1968); Tougher Law for Criminals-A Noted Judge's Proposal, U.S. NEws \& WORLD REP., Nov. 25, 1968, at 16; Falling Out With the Fifth, TIME, Nov. 29, 1968, at 92.

357 Friendly wrote:

Fortunately I never allowed myself to take seriously Mr. Nixon's mention of me as a candidate for the chief justiceship. Believe it or not I would not have wished to be Chief Justice. I am sure I would have been a very bad one and I would have 
a younger, more consistent Warren Court critic, D.C. Circuit Judge Warren Burger, had already caught Nixon's eye. ${ }^{358}$ Friendly predicted that Burger would get the job, and Friendly never wanted the Chief Justice's administrative responsibilities. ${ }^{359}$ Nixon's nomination of Clement Haynsworth on August 21, 1969 (followed by G. Harrold Carswell and Harry Blackmun) probably hurt more. ${ }^{360}$ After three months, the Senate rejected Haynsworth because of conflict of interest allegations. Friendly rebutted similar allegations in a letter to Rep. John Conyers (D-MI) ${ }^{361}$ Friendly's age, sixty-six, and Nixon's Southern Strategy doomed Friendly's Supreme Court chances. $^{362}$

Like Learned Hand, Friendly is "quite possibly the greatest twentiethcentury jurist never to sit on the Supreme Court."363 Friendly, like Hand, was

absolutely hated to do all of the things the present incumbent so enjoys, e.g., speaking at bar association meetings, maintaining contacts with Congress, and being a big wheel in Washington social life. The only time when I thought I might have a chance of an associate justiceship was at the time when you wrote. It happened that at about a month after the date of your letter Mitchell attended our Second Circuit Conference and this was put to him rather strongly by Ed Weinfeld, whom he had known when Ed was in private practice, and by John Harlan. He turned both of them off quite sharply with the age argument. Of course, this, as soon as it became apparent, had nothing to with my case since Nixon was determined to appoint a Southerner; as a result of which we have two justices from Minnesota.

Letter from Henry J. Friendly to Charles E. Wyzanski (Jan. 31, 1983) (on file with Friendly Papers, supra note 72, Box 220, Folder 220-4).

358 Richard NIXON, RN: THE MEMOIRS OF RICHARD NiXON 419-20 (1978) (recalling Burger's 1967 speeches in U.S. News \& World Report).

359 See Letter from Tom C. Clark to Henry J. Friendly 2 (May 24, 1969) (on file with Friendly Papers, supra note 72, Box 235, Folder "Scrapbook 1959-present") (congratulating Friendly on Burger prediction); supra note 354.

${ }^{360}$ Friendly's former clerk wrote him a telegram: "HAVE JUST LEARNEO [sic] THE BAD NEWS SORRY AND SORRY IN GENERAL THE BEST MAN DID NOT WIN MUST BE GOOD TO HAVE PRESSURE GONE THOUGH HOW YOU DISREGARDED ITT [sic] WAS MOST [I]MPRESSIVE PART OF MY CLERKSHIP." Telegram from former Friendly clerk to Henry J. Friendly (Aug. 22, 1969) (on file with Friendly Papers, supra note 72, Box 235, Folder "Scrapbook 1959-").

361 Sidney E. Zion, Who's Afraid of Judge Henry Friendly? (Besides the New York Times Et $A l$ ), SCANLAN's MONTHLY, May 1970, at 10-16 (on file with Friendly Papers, supra note 72, Box 234, Folder 234-10); Letter from Henry J. Friendly to John Conyers 1-6 (Aug. 28, 1969) (on file with Friendly Papers, supra note 72, Box 234, Folder 234-4) (rebutting allegations).

362 Nixon mentioned Friendly as "regional candidate" before selecting Lewis Powell. Nixon Tapes (Oct. 19, 1971) (on file with National Archives, Tape Log, Tape 596-3).

363 Akhil Reed Amar, Heller, HLR, and Holistic Legal Reasoning, 122 HARV. L. REV. 145, 181 (2008). 
not at his best writing about "issues of great social importance."364 If Friendly had served on the Court, he would have been associated with his Root, Clark mentor Harlan. Friendly was reluctant to strike down state statutes by finding new individual rights. For example, he drafted a mooted, pre-Roe opinion about a New York abortion law in which he rejected substantive due process and right to privacy arguments. ${ }^{365}$

And like Hand, Friendly probably made more impact on the law as one of three appellate judges deciding thousands of cases rather than one of nine Justices deciding hundreds. ${ }^{366}$ Friendly's opinions rewrote myriad areas of Second Circuit law, still stand as super-precedents, and are more cited than Hand's. ${ }^{367}$ Friendly often saw his opinions adopted by the Supreme Court. ${ }^{368}$

Friendly satisfied some of Brandeis's academic aspirations through extrajudicial scholarship. During his first five years on the Second Circuit, Friendly wrote fourteen law review articles. Friendly's articles allowed him to engage prominent judges and law professors by sending them reprints and addressed constitutional and administrative law topics that eluded him on the Second Circuit.

Friendly's scholarship, like Hand's, responded to the Supreme Court in provocative ways. During the 1970 s and 1980 s, Friendly questioned the expansion of habeas corpus in Fay v. Noia ${ }^{369}$ with Is Innocence Irrelevant: Collateral Attack on Criminal Judgments, ${ }^{370}$ the expansion of procedural due process requirements in Goldberg $v$. Kelly ${ }^{371}$ with Some Kind of Hearing, ${ }^{372}$ and criticized Brown v. Board of Education's lack of clear principle as

364 Leval, infra note 383, at 573; see Richard A. Posner, The Learned Hand Biography and the Question of Judicial Greatness, 104 YALE L.J. 511, 515 (1994) [hereinafter Posner, Learned Hand Biography] (arguing that Hand's contribution to constitutional law was scant and undistinguished).

365 A. Raymond Randolph, Administrative Law and the Legacy of Henry J. Friendly, 74 N.Y.U. L. REV. 1, app. at 1057 (1999) (reprinting Hall v. Lefkowitz). Imagine Roe v. Wade if Nixon had nominated Friendly instead of Harry Blackmun, who had finished 120 out of 451 at Harvard Law School. LINDA GREENHOUSE, BECOMING JUSTICE BLACKMUN 12 (2004).

366 Friendly Unveiling, 887 F.2d at CII (remarks of Judge Lumbard).

${ }^{367}$ Posner, Learned Hand Biography, supra note 364, at 539 (counting 107 citations from 1992 to 1994 to Friendly's 91 opinions from 1956 to 1961 compared to 41 citations from Hand's 84 opinions from 1956 to 1961). Of course, Hand was very old and Friendly was not confirmed until 1959. Id. at $535 \mathrm{n} .81$.

368 See infra text accompanying notes $410-15$.

369372 U.S. 391 (1963).

${ }^{370}$ Henry J. Friendly, Is Innocence Irrelevant?: Collateral Attacks on Criminal Judgments, 38 U. CHI. L. REV. 142 (1970).

371397 U.S. 254 (1970).

372 Henry J. Friendly, Some Kind of Hearing, 123 U. PA. L. REV. 1267 (1975). 
responsible for Roe $v$. Wade's substantive due process rationale. ${ }^{373}$ Before and after becoming a judge, Friendly wrote numerous book reviews, law review articles, and speeches idealizing and mythologizing Brandeis. Like Brandeis, Friendly did not publish clerk-drafted articles based on his ideas, but wrote everything himself. Being a judge enabled him to pursue his scholarly bent that Brandeis had encouraged him to follow all along.

Another aspect of Friendly's personality must be noted-his impatience. Friendly, unlike Hand, never yelled at counsel from the bench or threw briefs at them. ${ }^{374}$ But Friendly possessed a caustic tone and tart tongue. ${ }^{375}$ In 1961 , Friendly criticized new Second Circuit Judge Thurgood Marshall's "[p]ullman-porter joviality, and an addiction to name dropping and pretended intimacy with the entire federal bench." 376 Friendly was concerned that Marshall seemed "easily led" and failed to grasp "the difficulties of his job."377 Friendly's problem was that he held other judges, law clerks, lawyers, the Supreme Court, and law professors to an impossible standardthat of Friendly himself. Clerking for Friendly was as difficult as many mere mortals had found it clerking for Brandeis.

\section{Clerkship Model}

Brandeis's biggest influence on Friendly was Friendly's clerkship model. As a Second Circuit judge from 1959 to 1986, Friendly experienced the evolution of clerkships in American legal culture. The selection process changed from informal and professor-selected to formal applications and personal interviews. The role of law clerks changed from research assistant to that of ghostwriter. ${ }^{378}$ And the status of clerkships changed from nonideological first jobs to ideological identifiers and essential credentials.

Friendly, like Brandeis, did not hire law clerks; Friendly wanted disciples. $^{379}$ Future Stanford Dean Larry Kramer turned down a clerkship with then-D.C. Circuit Judge Antonin Scalia to be one of the last Friendly clerks. "The Friendly clerkship was much more like a discipleship ...,", recalled Kramer, whose non-legal tasks included picking up his dry cleaning.

373 Henry J. Friendly, The Courts and Social Policy: Substance and Procedure, 33 U. MIAMI L. REV. 21, 29-42 (1978).

${ }^{374}$ Friendly Unveiling, 887 F.2d at CII (remarks of Judge Lumbard); GUNTHER, supra note 57, at 620-21 (throwing paperweight at law clerk).

375 Wilfred Feinberg, In Memoriam, 99 HARV. L. Rev. 1709, 1714 (1986) ("It was common knowledge that Henry did not suffer fools gladly.").

376 Letter from Henry J. Friendly to Felix Frankfurter 1-2 (Jan. 9, 1962) (on file with FF-LC, supra note 34, Box 57, Folder "Friendly, Henry J. \#6").

377 Id. at 2.

378 See POSNER, FEDERAL COURTS, supra note 22, at 143.

379 Peppers, Isaiah and His Young Disciples, supra note 51. 
"I didn't even think of it as a job in the sense I was clocking hours. It wasn't a job. My life was to help him. That's what I did that year." 380

Friendly initially hired a "high-standing graduate of a first-rate law school" as a "law clerk" and a night law student for half the salary as a "messenger" to assist the secretary with ministerial tasks. ${ }^{381}$ Friendly eventually hired two elite clerks who shared both duties. Clerks learned about the "common law" of the Friendly chambers-when to clean his desk, which office door to walk through to retrieve a book, and when to respond to one of the two buzzers reserved for the clerks. ${ }^{382}$

A judicial conservative and Rockefeller Republican, Friendly hired clerks across the political spectrum. Friendly's former clerks include one Supreme Court Justice (Roberts), five federal appellate judges (Michael Boudin, William Bryson, Merrick Garland, Pierre Leval, and A. Raymond Randolph), prominent academics (Bruce Ackerman, Stephen Barnett, Philip Bobbitt, David Currie, Peter Edelman, Reinier Kraakman, Larry Kramer, Todd Rakoff, and Ruth Wedgwood), and leading members of the bar. The post-clerkship success of Friendly's clerks only added to his judicial reputation. Several Friendly clerks who became federal judges wrote law review articles lauding Friendly, just as Friendly and his fellow clerks had lauded Brandeis. ${ }^{383}$

Friendly valued intelligence over ideology because, like Brandeis, Friendly wrote his own opinions and wanted his clerks to challenge them. Friendly came of age as a lawyer when law partners wrote their own briefs and did not leverage work (and billable hours) to associates. And Friendly's scholarly pride would not have permitted him to delegate opinion-writing to clerks.

Friendly clerks did not write opinions or bench memos, but they worked as hard as their Brandeis forebears. The clerks divided cases among themselves. Before argument, they read the briefs, wrote research memos about issues not adequately covered in the briefs, and checked the record about disputed issues of fact. ${ }^{384}$ Most of all, they had to be prepared to

${ }^{380}$ Interview with Larry Kramer, Dean, Stanford Law School, in Palo Alto, California (Jan. 13, 2010) [hereinafter Kramer Interview].

381 MANUAL FOR LAW CLERKS 1 (1978) (on file with Friendly Papers, supra note 72, Box 232, Folder 232-7) [hereinafter LAW CLERK MANUAL].

382 Kramer Interview, supra note 380.

383 See, e.g., Michael Boudin, Memoirs in a Classical Style, 133 U. PA. L. REV. 1 (1984); Pierre N. Leval, Henry J. Friendly: In Memory of a Great Man, 52 BROOK. L. REV. 571 (1986); A. Raymond Randolph, Administrative Law and the Legacy of Henry J. Friendly, 74 N.Y.U. L. REV. 1 (1999); A. Raymond Randolph, Before Roe v. Wade: Judge Friendly's Draft Abortion Opinion, 29 HARV. J.L. \& PUB. POL'Y 1035 (2006); Boudin, Madison Lecture, supra note 246.

384 Id; LAW CLERK MANUAL, supra note 381 , at I.C. 
discuss the cases with the judge. Discussing cases with Friendly could be terrifying. According to Friendly's clerkship manual:

The process of weighing the opposing contentions, reaching a conclusion of your own, and then checking your view against the Judge's will be one of the most intellectually challenging aspects of your clerkship experience. When your reaction does not coincide with the Judge's, don't give in without a fight; he wants to hear your view, and is far from averse to changing his mind, not only at this early stage in the decisional process, but-with decreasing likelihood-at any time before the final opinion is filed. ${ }^{385}$

After oral argument, the three judges on the panel circulated postargument voting memos indicating how they intended to vote. Friendly dictated his voting memos to his secretary as his clerks proofread them, refined arguments, and made suggestions. The clerks then read other judges' voting memos before the conference the following week. ${ }^{386}$ Friendly, like Brandeis, sometimes assigned his clerks research projects, especially in harder cases. "Most likely these will concern detailed examination of a long record or intensive research into cases, law reviews or legislative history," Friendly's clerkship manual said. ${ }^{387}$

Friendly often drafted opinions in a single day without leaving his private office. The opinions would be complete with string citations, quotations from Second Circuit opinions (usually Learned Hand's), and references to the record. "In a complex case, he would sit down, in longhand, writing in the same speed in which he were copying previously written text, he would compose a perfect opinion," Leval recalled, "[h]e hardly ever needed to grope to find the best way to express it. It was simply astonishing." 388 Peter Edelman believed that Friendly had a "little magic tunnel" from his office to the library to retrieve citations in a pre-computer era. ${ }^{389}$ Leval believed that Friendly "had almost no need for clerks."390 Friendly's secretary typed two copies of draft opinions, one for Friendly and one for the clerk ${ }^{391}$ _ just as the Supreme Court's printer had done for Brandeis. Friendly then revised the first copy and showed it to his clerk. The

385 LAW CLERK MANUAL, supra note 381, at I.C.

386 Id.

387 Id. at I.E.

388 Telephone Interview with Pierre Leval, Judge, Second Circuit Court of Appeals (Nov. 24, 2009) [hereinafter Leval Telephone Interview].

389 Interview with Peter Edelman, Professor, Georgetown Law School, in Washington, D.C. (Aug. 6, 2009) [hereinafter Edelman Interview].

390 Leval Telephone Interview, supra note 388.

391 LAW CLERK MANUAL, supra note 381, at II.C. 
clerk's duties included cite-checking cases and fact-checking against the record. The clerk's viewpoint mattered most. The manual said:

Substance is far more important. The Judge welcomes criticism; challenge the draft in every reasonable way you can. Assume, at the start, that everything said, by way of fact or law, may be wrong (or incomplete) and make sure it is or becomes right. ... Keep your mind open to further points which may strengthen the force of the opinion or, on the other hand, to difficulties in its reasoning or future effect. This is your most important single function. ${ }^{392}$

Clerks prepared inserts with additions or revisions that Friendly usually accepted, another practice adopted from Brandeis. ${ }^{393}$ Longer revisions usually required a discussion or brief memo.

The biggest hurdle to contributing to Friendly's opinions was matching his lightning pace and contending with his impatience. Friendly's clerkship manual advised:
Always remember that the Judge wants your critical comments as well as checking. Don't worry if he sometimes seems impatient for quick results- he wants you to be thorough above all. Only occasionally will there be an opinion in which time is really of the essence. Save for these, with respect to which he will inform you, REFUSE TO BE HURRIED! If, after you think you have finished your work, you believe a night's reflection on an opinion would help, insist on taking it. ${ }^{394}$

Friendly usually arrived at the office between 9:30 a.m. and 10:30 a.m., and, like Brandeis, left between 4:30 and 5:30 p.m. but often took work home with him. His clerks often worked into the night. Kramer pulled five or six all nighters, the only ones of his life. ${ }^{395}$

Friendly's cold, business-like personal interactions with his clerks were similar to Brandeis's interactions with his clerks. During the clerkship, Friendly's clerks were not his sons, friends, or confidants. "He taught instead entirely by example," Ackerman wrote. "He did his work; you did yours; and

392 Id. at I.E.

${ }^{393}$ Letter from Friendly to Nathanson (June 3, 1963), supra note 142 ("I remember Bob Page's remark that the Justice would always take his law clerk's suggestion for the phrasing of a passage in an opinion rather than his own, unless he thought the clerk's substantially worse - an attitude which I think is a pretty good one for any judge to follow, particularly since the clerk's suggestions are usually better.").

394 LAW CLERK MANUAL, supra note 381 , at I.E.

395 Kramer Interview, supra note 380. 
then you worked together ... in the craft of the law."396 Leval once knocked on Friendly's office door with trepidation; Friendly's secretary advised Leval: "Don't open it till you're sure you know exactly what you want to say." 397 Indeed, Leval loved Friendly but described him as "formidable and intimidating" and with a "widespread ... reputation for temper and impatience." 398 Kramer "had lunch with him once, my last day, to tell me what he thought of me." 399 The clerks all knew the line that "Judge Friendly was not [friendly]." 400

Yet Leval argued that "the Judge's reputation for impatience was overstated" and "[w]orking as his clerk was matchlessly rewarding." Leval, "timid and insecure," spent the first three months of his clerkship awestruck by Friendly's speed and intelligence, intimidated by Friendly's "gruff" demeanor, and not "contributing anything of significant value" to Friendly's opinions. ${ }^{401}$ The turning point came when Leval found the "courage" to disagree with Friendly's explanation of several cases cited in an opinion. ${ }^{402}$ Leval wrote of Friendly: "'Well,' he purred, '[w]e've got a real disagreement here. Let's have a look.' ... He reread the cases, and then, with an even broader smile, declared that I was right; "how would we fix it up?"'403 The moment raised Leval's confidence and changed the rest of his clerkship experience because Leval had discovered what Friendly wanted - "intelligent disagreement." "He was never happier than when a law clerk confronted him with an interesting disagreement," Leval said at Friendly's memorial service. "I have often heard him speak fondly of one of my successors, who I see here today, as the law clerk who turned him around more often than any other." 404

396 Bruce A. Ackerman, In Memoriam: Henry J. Friendly, 99 HARV. L. REV. 1709, 1711 (1986) [hereinafter Ackerman, In Memoriam].

${ }^{397}$ In Memoriam, 805 F.2d at LXXXV, XCVI-XCVII (1986) (reprinting Pierre Leval's tribute to Friendly).

398 Id. at XCVII.

${ }^{399}$ Kramer Interview, supra note 380.

400 Author Interview.

${ }^{401}$ Interview with Pierre Leval, Judge, Second Circuit Court of Appeals, in New York, N.Y. (June 17, 2010) [hereinafter Leval Interview].

402 Id.

403 In Memoriam, 805 F.2d at XCVII (1986).

404 Id. The clerk was Northeastern University law professor Richard Daynard, though Judge Michael Boudin was Friendly's "all-time favorite clerk." Leval Interview, supra note 401; Leval Telephone Interview, supra note 388 . Friendly wrote that "all the law clerks, who have been an extraordinarily able group, recognize [Boudin] as primus inter pares." Letter from Henry J. Friendly to Committee on Membership, The Century Association (May 10, 1982) (on file with Friendly Papers, supra note 72, Box 220, Folder 220-2). 
Philip Bobbitt wrote Friendly that the clerkship was difficult yet satisfying:

When I forgot to punch holes in your slip opinions or sent home the wrong briefs for you to read, you must have thought you were the unluckiest man in the world. And considering the weight of responsibilities you carried, there may have been something to that. But I count myself as one of the luckiest of men because I had the chance at an early age to see law being done the way it ought to be done. The impression, like a template, has always stayed with me: an example of meticulous care, a courageous disdain, and a high intelligence applied to the frequently mundane difficulties of getting difficult problems right. 405

Ackerman once disagreed with pages 137-93 of Friendly's 227-page, triplespaced draft that the judge had written in four days. Friendly asked Ackerman to write an alternative draft. Three weeks later when Ackerman finished, they revised it together for hours until they had crafted an entirely different draft "in ways neither of us had clearly anticipated. . . . The result is an opinion far stronger . . . than either of the earlier drafts."406

Friendly adopted Brandeis's teaching-by-example approach. Like Brandeis, Friendly wanted his clerks' substantive suggestions. Unlike Brandeis, Friendly was able to see the other side and sometimes changed his mind about the merits. Friendly welcomed dissenting views whereas Brandeis seemed to shut them down. Friendly, like Brandeis, wrote the first draft to the last. The experience was one Friendly clerks never forgot.

The final similarity between the Friendly and Brandeis clerkships was the changing post-clerkship relationship. Friendly took great interest in his clerks' careers. He recommended them for Supreme Court clerkships. ${ }^{407} \mathrm{He}$ advised them about careers in academia and government and, unlike Brandeis, regarded private practice as good training. ${ }^{408}$ About underperforming or even his favorite clerks, he minced no words in written or oral evaluations. He sponsored or co-sponsored clerks for admission to the American Law Institute, ${ }^{409}$ the Council on Foreign Relations, ${ }^{410}$ and New

405 Letter from Philip Bobbitt to Henry J. Friendly (Mar. 13, 1984) (on file with Friendly Papers, supra note 72, Box 221, Folder 221-6).

406 Ackerman, In Memoriam, supra note 396, at 1710.

407 See infra notes 432, 434, 453.

408 Letter from A. Raymond Randolph to Henry J. Friendly 2 (Apr. 14, 1977) (on file with Friendly Papers, supra note 72, Box 210, Folder 210-11); Edelman Interview, supra note 389.

${ }^{409}$ Letter from Stuart Strock to Henry J. Friendly (June 27, 1979) (on file with Friendly Papers, supra note 72, Box 219, Folder 21-5) (recommending Strock); Letter from Henry J. Friendly to Committee on Membership (Aug. 25, 1981) (on file with Friendly Papers, supra note 72, Box 220, Folder 220-1) (recommending Bobbitt). 
York's elite Century Association. ${ }^{411} \mathrm{He}$ corresponded with clerks and commented on drafts of their books and law review articles. ${ }^{412}$ Friendly was an impossible standard to live up to, but his former clerks, a talented bunch, often spent their careers trying.

\section{THE FRIENDLY CLERKSHIP, 1959-1986}

By the time John Roberts, then a second-year student at Harvard Law School, applied for clerkships in spring of 1978, the status of clerkships in American legal culture had begun to change. The informal, professorselected process had waned. Clerkships were morphing into highly competitive ideological identifiers and essential credentials. Lower court clerkships were becoming prerequisites for Supreme Court clerkships. The Brethren, a 1979 exposé about the Court based on interviews with clerks, revealed the Court's divisions and returned clerkships to the national radar.

Even after taking senior status at age 70 in 1974, Friendly attracted applications from all the Harvard Law Review editors and top students at other schools. Aspiring law clerks in Harvard's class of 1979 viewed Friendly's clerkship as "the gold standard."413 But Review editors knew about Friendly's demanding reputation and unusual clerkship model - not requiring bench memos and forcing clerks to think on their feet. "Everyone at the Law Review would have sent him an application," recalled Charles

${ }^{410}$ Letter from Henry J. Friendly to Lorna Brennan (Feb. 28, 1983) (on file with Friendly Papers, supra note 72, Box 220, Folder 220-4) (recommending former clerk William T. Lake); Letter from William T. Lake to Henry J. Friendly (Mar. 5, 1983) (on file with Friendly Papers, supra note 72, Box 220, Folder 220-4) (expressing thanks for seconding nomination).

${ }^{411}$ Letter from Henry J. Friendly to Membership Committee (Aug. 20, 1954) (on file with Friendly Papers, supra note 72, Box 221, Folder 221-1); Letter from Pierre Leval to Henry J. Friendly (May 8, 1979) (on file with Friendly Papers, supra note 72, Box 219, Folder 219-5) (thanking for recommendation); Letter from Friendly to Committee on Membership (May 10, 1982), supra note 404 (recommending Boudin).

412 Letter from Henry J. Friendly to Philip Bobbitt (Feb. 1, 1982) (on file with Friendly Papers, supra note 72, Box 220, Folder 220-2); Letter from Philip Bobbitt to Henry J. Friendly (Apr. 30, 1982) (on file with Friendly Papers, supra note 72, Box 220, Folder 220-2); Letter from Bobbitt to Friendly (Mar. 13, 1984), supra note 405; Letter from Henry J. Friendly to Philip Bobbittt (Mar. 19, 1984) (on file with Friendly Papers, supra note 72, Box 221, Folder 221-6); Letter from Henry J. Friendly to Bruce Ackerman (Sept. 26, 1983) (on file with Friendly Papers, supra note 72, Box 221, Folder 221-6); Letter from Bruce Ackerman to Henry J. Friendly (Sept. 28, 1983) (on file with Friendly Papers, supra note 72, Box 220, Folder 220-6); Letter from Henry J. Friendly to Merrick Garland (July 16, 1985) (on file with Friendly Papers, supra note 72, Box 221, Folder 221-6).

413 Telephone interview with Charles Davidow (Aug. 19, 2009) [hereinafter Davidow Interview]. 
Davidow, who served on the Review with Roberts and then roomed with him during their Second Circuit clerkships, "but there was a fear factor associated with Judge Friendly. You would want the Friendly clerkship, but you would be a little nervous about applying." 414

Review editors also applied to Friendly because he was a "feeder" judge who sent twenty clerks to the Court. 415 Although Friendly fed clerks from Brennan to Rehnquist, the feeder judge concept added an ideological dimension to clerkships. Friendly was viewed as the antidote to liberal feeder Judges David Bazelon and J. Skelly Wright.

Friendly usually selected one Harvard clerk and relied on his current Harvard clerk and clerk-in-waiting to identify Review editors whom Friendly might want to interview. 416 On the first day of spring selection period, Friendly called his first choice for the 1979-1980 term, future Chief Justice John G. Roberts.

\section{A. Roberts's Background}

Roberts and Friendly had similar backgrounds. They both came from upstate New York and lived in small towns. Born in Buffalo on January 27, 1955, John Glover Roberts grew up in the 1500-person town of Long Beach, Indiana. They both were raised in affluent homes. A Bethlehem Steel executive, Roberts's father moved his family to Indiana to work as an electrical engineer and help manage one of the company's nearby steel mills. Roberts attended private Catholic schools and high school at La Lumiere, an all-boys boarding school in LaPorte, Indiana. They both excelled academically. Roberts balanced academic achievement with popularity, finishing first in his class and serving as captain of the school's football team though he was an undersized, mediocre athlete. Roberts was such a gifted student that he entered Harvard College with sophomore standing.

Roberts, like Friendly, attended Harvard for college and law school and majored in history. Roberts wanted to study European intellectual history and become a professor. ${ }^{417}$ His first-year sophomore essay, "Marxism and Bolshevism: Theory and Practice," won the William Scott Ferguson Award

${ }^{414} I d$.

415 PEPPERS, supra note 15, at 34 tbl.2.6.

416 Interview with Paul Mogin, in Washington, D.C. (Aug. 11, 2010) [hereinafter Mogin Interview].

417 Chief Justice John G. Roberts, Jr., Address at the University of Alabama Law School (Mar. 9, 2010), available at http://www.c-spanarchives.org/program/292439-1 [hereinafter Roberts Alabama Speech] (discussing aspiration to be a history professor); Adam M. Guren, Alum Picked As Court Nominee, HARv. CRIMSON, July 22, 2005 [hereinafter Guren, Alum Picked As Court Nominee]; Adam M. Guren, Roberts Cut Legal Teeth Early, HARV. Crimson, Sept. 16, 2005. 
for the "the outstanding essay submitted by a sophomore concentrating in History." 418 Roberts's senior essay, "The Utopian Conservative: A Study of Continuity and Change in the Thought of Daniel Webster," won the 1976 Bowdoin Prize, the same prize that Friendly had won fifty years earlier. The prize caught Friendly's eye; he circled it on Roberts's résumé. 419

Roberts's 166-page senior thesis, "Old and New Liberalism: The British Liberal Party's Approach to the Social Problem, 1906-1914," criticized the Party for relying on the charismatic personalities of David Lloyd George and Winston Churchill rather than confronting social problems. ${ }^{420} \mathrm{He}$ graduated summa cum laude from Harvard College in three years, choosing law school over a full scholarship to Harvard's doctoral history program and Harvard Law over Stanford in part because "his Stanford interviewer wore sandals and no tie." 421

Though not a once-in-a-generation law student like Brandeis or Friendly, Roberts graduated magna cum laude and was one of the top students in Harvard Law School's Class of 1979. Based on access to the grades of the 550 members of the class, the Harvard Law Review invited the top fifteen students after their first year to be editors; Roberts was one of them. ${ }^{422}$ "John was a superstar in law school, and the fact that Friendly picked him would be testament to that," Davidow recalled. ${ }^{423}$ Friendly had additional proof of Roberts's class standing during his second year-the incoming Review president, David Leebron, selected Roberts to be the ninety-second volume's managing editor. The managing editor was in charge of ensuring that editors met their deadlines and published issues on time. Roberts wrote an unsigned student note on the Takings Clause (which he later disavowed) 424 and unsigned comments on the Contract Clause and the media's First

418 Matthew Continetti, John Roberts's Other Papers, The WeEkLY STANDARD, Aug. 8, 2005, at 9 .

419 Friendly Papers, Box 210; Interview with Richard Lazarus, Professor, Georgetown Univ. Law Ctr., in Washington, D.C. (Aug. 10, 2010) [hereinafter Lazarus Interview].

420 Continetti, supra note 418.

421 Guren, Alum Picked As Court Nominee, supra note 417.

422 Guy Taylor, Roberts Made His Mark Quietly Early at Harvard, WASH. TIMES, Sept. 2, 2005, at A1.

423 Davidow Interview, supra note 413.

424 Confirmation Hearing on Federal Appointments: Hearing Before the S. Comm. on the Judiciary, 108th Cong., 1st Sess. 422 (2003) [hereinafter Roberts D.C. Circuit Hearings] (written submission by John G. Roberts, Cir. Ct. nominee, to a question submitted by Sen. Russell D. Feingold: "I would not follow my student note [on the Takings Clause]; no one else has."). 
Amendment right to access. ${ }^{425}$ According to Paul Mogin, one of Roberts's law school roommates and successor in Friendly's chambers, Roberts frequently slept on a cot in the Review's Gannett House offices. Roberts, Mogin said, shared Friendly's capacity for hard work and devotion to the law. ${ }^{426}$

Unlike many type-A gunners, Roberts endeared himself to his classmates with his innate modesty and self-deprecating sense of humor. He did not walk the halls or tunnels of the law school bragging about his Friendly clerkship. "John was very, very well-liked there," Davidow recalled. "He's almost impossible for anyone not to like. It was nice to see him get that clerkship." 427

In college and law school, Roberts projected a Midwestern reserve and quiet conservatism. He arrived at Harvard a fully-formed conservative on a Cambridge campus dominated by liberals, ${ }^{428}$ but he abstained from ideological warfare. He did not join the Rehnquist Club, a Federalist Society precursor established by conservative law students. ${ }^{429}$ Nor did he allow his conservatism to prevent him from making lasting friendships across the political spectrum. He chose Richard Lazarus, a liberal Georgetown law professor whom Roberts had met in law school and roomed with in Washington, D.C., to speak at Roberts's 2003 investiture at the D.C. Circuit. The other people Roberts asked to speak were Chief Justice William Rehnquist and former D.C. Circuit Judge and Solicitor General Kenneth Starr. 430

Roberts may have been more attracted to a clerkship with Friendly than D.C. Circuit liberals J. Skelly Wright or David Bazelon, but Roberts's conservatism made no difference to Friendly. Friendly valued Roberts's Harvard pedigree, his Bowdoin Prize and other prize-winning historical essays, and his high law school grades. The two men shared small-town backgrounds, research and writing ability, love for history, and devotion to the law. On the morning of May 30, 1978, Roberts traveled from Cambridge to Friendly's Foley Square chambers to interview for a clerkship. ${ }^{431}$ Friendly

425 Note, The Takings Clause, Developments in the Law-Zoning, 91 HARV. L. REV. 1462 (1978); Comment, Contract Clause-Legislation Alteration of Private Pension Agreements, 92 HARV. L. REV. 86 (1978); Comment, First Amendment-Media Right of Access, 92 HaRV. L. Rev. 174 (1979); JoHN G. RoberTS, U.S. S. COMM. ON THE JUDICIARY, DISCLOSURE FORM, at 8 (on file with author).

426 Mogin Interview, supra note 416.

427 Davidow Interview, supra note 413.

428 Janny Scott, Roberts's Roots As Conservative, N.Y. TIMES, Aug. 21, 2005, at 1.

429 Grunwald \& Goldstein, supra note 4.

${ }^{430}$ Lazarus Interview, supra note 419.

431 HenRy J. FrIENDLy, DAYBoOK PlanNER (1978) (on file with Friendly Papers, supra note 72, Box 160, Folder 160-3). 
offered him the job that same day, and Roberts accepted. Roberts had finished his second year of law school and was headed to Hawaii to work for a Honolulu law firm. The following June, Roberts began working as Friendly's clerk.

\section{B. Roberts's Clerkship Experience}

Roberts reported for work sooner than expected in early June and impressed Friendly. "John Roberts is already at work and I am sure you will find him an agreeable colleague," Friendly wrote Roberts's co-clerk, Yale law graduate and future Harvard corporate law professor Reinier Kraakman, on June $21,1979.432$

After another month, Roberts had earned Friendly's trust and confidence. On July 25, 1979, Friendly wrote Roberts letters of recommendation for Supreme Court clerkships:

While normally, I would be hesitant to make a firm recommendation with respect to a law clerk so early in the year, I have absolutely no such hesitation in the case of John Roberts.

He arrived early in June since both clerks of the previous term wished to leave early. He immediately took over the portion of the clerk's work which involves the running of the office and mastered that within a couple of days. Since then he has been working with me on opinions (including one for the Special Court under the Rail Reorganization Act)-a job made more difficult by the fact that he had not been here to participate in the preparation for argument and conference. He has performed superbly, examining my drafts with a critical eye, submitting counter-arguments, and drafting proposed changes which can be accepted with small, if any, change. He works quickly but thoroughly and writes extremely well. In short, I am completely certain, even at this early date, that he will rank among my very best clerks and I recommend him wholeheartedly without the slightest reservation. ${ }^{433}$

At the end of each letter, Friendly compared Roberts to one of his former clerks he had sent to the Justice. "I understand that you were very satisfied with Ruth [Wedgwood]," Friendly wrote Blackmun. "I am sure you would be equally so with John Roberts." 434 Friendly wrote the letters on July 25,1979 because Rehnquist had already contacted Roberts about an interview.

432 Letter from Henry J. Friendly to Reinier Kraakman (June 21, 1979) (on file with Friendly Papers, supra note 72, Box 219, Folder 219-2).

433 Letter from Henry J. Friendly to Harry Blackmun (July 25, 1979) (on file with Friendly Papers, supra note 72, Box 210, Folder 210-28).

434 Id. 
Friendly was leaving for vacation until the end of August and wanted Rehnquist and other Justices to know his high opinion of Roberts. ${ }^{435}$

Friendly's Papers make it difficult to reconstruct meaningful details about Roberts's clerkship. Friendly did not save handwritten drafts of his opinions, perhaps because of the Second Circuit's heavy caseload. Many of Roberts's cases with Friendly were mundane compared to landmark cases like Olmstead that Friendly had worked on with Brandeis. In addition to his Second Circuit caseload, Friendly served as one of three judges on the Special Court under the Rail Reorganization Act. ${ }^{436}$ Friendly's railroad opinions were massive, hypertechnical, and, even to Friendly, "boring."437

Friendly's Papers reveal some of Roberts's clerkship duties. Just as Friendly had done for Brandeis, Roberts wrote memos on discrete issues. ${ }^{438}$ Roberts responded to Friendly's requests for citations or information and made substantive suggestions. ${ }^{439}$

Friendly considered Roberts's clerkship year a success in part because the Supreme Court granted cert in three of Friendly's cases and sided with Friendly in every one. In Merrill Lynch, Pierce, Fenner \& Smith, Inc. v. Curran, ${ }^{440}$ the Court affirmed Friendly's opinion finding an implied private right of action under the Commodities Exchange Act and Justice Stevens's majority opinion deferred to Friendly's interpretation of the Act's legislative history. ${ }^{441}$ The Court also affirmed the Second Circuit's Hydrolevel opinion, which Friendly joined, finding a trade organization guilty of antitrust

435 Letter from Henry J. Friendly to William Rehnquist (July 25, 1979) (on file with Friendly Papers, supra note 72, Box 210, Folder 210-28).

436 See Henry J. Friendly, From a Fellow Worker on the Railroads, 60 TuL. L. REV. 244, 244 (1986); Wisdom, supra note 339, at 67-77.

${ }^{437}$ Letter from Henry J. Friendly to Michael Boudin (Aug. 25, 1981) (on file with Friendly Papers, supra note 72 , Box 220, Folder 220-1) ("I am having a rather boring time myself-working on the gigantic opinion of the Special Court with the dismal feeling that the whole case may be settled out from under us. I wish there was some decent way of getting out of this but none appears.").

438 Memorandum from John G. Roberts to Henry J. Friendly (Nov. 6, 1978) (on file with Friendly Papers, supra note 72, Box 97, Folder 97-1) (United States v. Ochs); Memorandums from John G. Roberts to Henry J. Friendly (Dec. 1, 1978) (on file with Friendly Papers, supra note 72, Box 95, Folder 95-1) (ITT World Commc'ns v. FCC); Memorandum from John G. Roberts to Henry J. Friendly (Dec. 26, 1978) (on file with Friendly Papers, supra note 72, Box 97, Folder 97-1) (United States v. Ochs); Memorandum from John G. Roberts to Henry J. Friendly (June 4, 1979) (on file with Friendly Papers, supra note 72, Box 90, Folder 90-18) (Ambook Enters. v. Time, Inc.).

439 ITT World Commc'ns v. FCC, draft opinion, 6, 6A, 16 (on file with Friendly Papers, supra note 72, Box 95, Folder 95-1).

440456 U.S. 353 (1982).

441 Id. at 387 n.86, 390 (relying on Leist v. Simplot, 638 F.2d 283 (2d Cir. 1980)). 
violations under a theory of apparent authority ${ }_{442}$ Finally, in Schweiker v. Hansen ${ }^{443}$ the Court reversed the Second Circuit's majority opinion granting retroactive Social Security benefits, and instead followed Friendly's dissent. ${ }^{444}$ "We certainly did well with the Supreme Court in the cases resulting from the year of your and John's clerkship," Friendly wrote Roberts's co-clerk, Reinier Kraakman. ${ }^{445}$ Kraakman recalled of Friendly and Roberts: "There was a bond between them." 446

\section{Roberts's Career Path}

\section{Rehnquist Clerkship}

The bond between Roberts and Friendly grew and the Friendly mythology began during Roberts's Supreme Court clerkship. With Friendly's approval, Roberts finished his clerkship in late May and on the first of July began working for Rehnquist. Many former Friendly clerks began their idealization and worship of Friendly during their Supreme Court clerkships. They were enthralled with Friendly's judicial model-writing his own opinions, wrestling with legal issues, and producing the best possible opinions regardless of the results-and found clerking on the Supreme Court a letdown. They viewed Friendly as an intellectual, fair-minded judge and the Justices as results-oriented politicians.

Pierre Leval eschewed clerking for the Supreme Court altogether. He made what he later described as a "dumb" decision in turning down a clerkship with Justice Harlan and a second offer from Harlan or Brennan. At the time, Leval's choice made sense: "I felt that I had clerked for a judge who was so much stronger in terms of intellectual capabilities than any of the judges on the Supreme Court that it would be a letdown." 447 Twenty Friendly clerks accepted Supreme Court clerkships, which some found wanting compared to their Friendly clerkships.

Gary Born, a Friendly and Rehnquist clerk two years after Roberts, wrote Friendly during his Rehnquist clerkship:

442 Am. Soc. of Mech. Eng'rs, Inc. v. Hydrolevel Corp., 456 U.S. 556, 559 (1982), aff'g Hydrolevel Corp. v. Am. Soc. of Mech. Eng'rs, Inc., 635 F.2d 118 (2d Cir. 1980).

443450 U.S. 785 (1981) (per curiam).

444 Id. at 788 (following Hansen v. Harris, 619 F.2d 942, 949 (Friendly, J., dissenting)).

445 Letter from Henry J. Friendly to Reinier Kraakman (June 9, 1982) (on file with Friendly Papers, supra note 72, Box 220, Folder 220-2).

446 E-mail from Reinier Kraakman to author (Feb. 21, 2010) (on file with author).

${ }^{447}$ Leval Telephone Interview, supra note 388. 
The year has been going extremely well for me. Nonetheless, I think I share with Mike Boudin's view that a Friendly clerkship is a much better clerkship than a clerkship here. At times it seems as though my job is more a matter of drafting statutory language to reflect a legislative compromise than of trying to reach a reasoned result. I suppose that is almost inevitable on a nine person Court though. ${ }^{448}$

\section{During his Brennan clerkship, Larry Kramer wrote Friendly:}

I really miss working for you. I don't want to give the wrong impression by seeming to compla[i]n too much, for I like this job a lot. The cases are all challenging and many of them are really fascinating. Justice Brennan is a wonderful man to work for, and the other clerks are all both very nice and very smart. But there are a few things about the job that I am less pleased with. There are too many clerks. We all work on everything, and since we all think very differently, it's hard to feel completely satisfied with the final work product because, whatever it is, it invariably includes a lot of ideas I disagree with. (And we haven't even gotten to writing opinions yet!) Mostly, though, I am dissatisfied with the Court as an institution. Last year, I always felt like I was working for a judge who viewed himself as a member of a court. (And I must thank you for the training I received which I am only now beginning to fully appreciate.) I knew that I could approach every case with an open mind, formulate my ideas as to the proper result based on the law, and have that idea seriously considered (if not ultimately accepted). Here, my job is largely to manipulate cases to get the "right" result, the right result having been determined beforehand and without reference to the law.... What I miss the most from last year is the "law intenseness" with which we worked on cases. For me, that's the fun of being a lawyer. 449

Kramer's admiration for and idealization of Friendly continues to this day. "No one in our era could have been more influenced by their clerkships with Supreme Court justices because, in our era, those guys were all lightweights [compared to Judge Friendly]," Kramer recalled.450 Kramer described his Friendly clerkship as "the single best learning experience I ever had in law."451

${ }^{448}$ Letter from Gary Born to Henry J. Friendly (Jan. 24, 1983) (on file with Friendly Papers, supra note 72, Box 220, Folder 220-4). Boudin agreed with Born's characterization. Interview with Micheal Boudin, Judge, First Circuit Court of Appeals, in Boston, Mass. (June 22, 2010) [hereinafter Boudin Interview].

${ }^{449}$ Letter from Larry Kramer to Henry J. Friendly 1-2 (Sept. 25, 1985) (on file with Friendly Papers, supra note 72, Box 221, Folder 221-6).

${ }^{450}$ Kramer Interview, supra note 380.

451 Id.; Eric Nee, From the Big Apple to the Farm, STANFORD LAWYER, Fall 2004, at $10-12$. 
Roberts conveyed more diplomatic impressions of the Court than Born or Kramer. On November 1, 1980, Roberts wrote Friendly and described his Rehnquist clerkship as "invigorating":

Nothing that I have witnessed suggests that there will be any lessening of the divisions on the Court this Term, but I was pleased to see that the rumors of personal animosity and pettiness circulating in the wake of The Brethren do not seem to have any substance. The Justice is at once amiable and challenging, and very open with me and my two co-clerks.

It must be an exciting time in chambers with preparations for the onslaught of the Railroad case. Should the case bring you to Washington, I hope you will be able to join me for a lunch or dinner, perhaps with others from the thriving colony of your ex-clerks down here. In any event, I will soon have to confront the question of what to do when this clerkship ends, and will be seeking your advice at that time. ${ }^{452}$

Friendly was not far from Roberts's thoughts. When appendicitis landed Roberts in the hospital, he had "briefs and cert petitions brought over and was able to continue working on them with only occasional interruptions by doctors and nurses." 453 Roberts was "mindful of the example" Friendly had set the previous year during his hospitalization with endocarditis. ${ }^{454}$

By November 1980, Roberts had impressed Rehnquist. "John Roberts is proving to be an absolutely first-rate law clerk," Rehnquist wrote Friendly, "and I hope that if you have any more like him you will not hesitate to let me know if they have an interest in clerking for me."455 In those days, Rehnquist, an Associate Justice, was still "the Lone Ranger" intent on empowering the states at the expense of the federal government but usually without the votes to accomplish it. At that point in his judicial career,

452 Letter from John G. Roberts to Henry J. Friendly (Nov. 1, 1980) (on file with Friendly Papers, supra note 72, Box 219, Folder 219-5).

453 Id

454 Id. ㄴetter from John G. Roberts to Henry J. Friendly (Feb. 3, 1983) (on file with Friendly Papers, supra note 72, Box 220, Folder 220-2) ("I was distressed to learn that you have had another bout with the same malady that afflicted you during the 1979 term."); Letter from Henry J. Friendly to John G. Roberts (Feb. 8, 1983) (on file with Friendly Papers, supra note 72, Box 220, Folder 220-2) ("This year's attack was much less serious than that of four years ago.").

455 Letter from William Rehnquist to Henry J. Friendly 2 (Nov. 21, 1980) (on file with Rehnquist Papers, Hoover Institution, Palo Alto, California, Box 114, Folder 4 ' ' F' 1980-81"); see Letter from William Rehnquist to Henry J. Friendly (Sept. 2, 1981) (on file with Rehnquist Papers, Hoover Institution, Palo Alto, California, Box 114, Folder 4 “"F' 1980-81") ("After my excellent experience with John Roberts, I will certainly give [Lewis Kaplow's] application careful consideration."). 
Rehnquist did not display much respect for precedent. ${ }^{456}$ Instead of writing exhaustive opinions that defined entire areas of law, Rehnquist emphasized results and efficiency over detailed reasoning. ${ }^{457}$ Rehnquist required his clerks to write first drafts within ten days after receiving an assignment. Rehnquist strictly enforced the "ten-day rule." "When a clerk would suggest that he could do a better job with a bit more time," Roberts wrote, "the Chief would explain that the idea was not for the clerk to do the best job, but for the Justice to do so, and whatever refinements the clerk might make over those ten days were unlikely to advance that objective."458 Rehnquist prized brevity over breadth. Roberts recalled:

I do remember doing a draft for him once, and coming in and he had thought that it was sort of the first topic sentence of each paragraph was good, and the rest of it could be junked. You know, I pushed back a little bit as I hoped was appropriate, and he said at that point, he said, "Well, I'll tell you what. Why don't we put all this other stuff down in footnotes? We'll just keep sort of the first sentence of each paragraph, put the rest down in footnotes." And I figured, well, that was a fair compromise.

So I would go back and rework it, and hand it to him with some pride, and he looks at it and he says, "Well, all right. Now take out the footnotes."

\section{[Laughter.]}

So one thing I learned from him was, I hope, to try to write crisply and efficiently, that a lot of extra stuff could be dispensed with, and just-so many people mentioned it during his eulogies and at the sort of gathering of the clerks, his general approach to the balance between work and family life. I think that was a very important lesson to learn at an early age. ${ }^{459}$

During the 1980 Term, Rehnquist was not at his best. In late July and early August 1980, he spent a week in the hospital with severe back pain from a degenerative disc. ${ }^{460}$ Rehnquist later wrote Roberts's co-clerk Dean Colson about a novel "which John had brought over to the hospital for me to read

456 Owen Fiss \& Charles Krauthammer, The Rehnquist Court, THE NEW REPUBLIC, Mar. 1982, at 14-21.

457 See William H. REHNQUist, The SUPREME COURT 298-301 (1987).

${ }^{458}$ Roberts, supra note 1, at 14-15 (Rehnquist did not require bench memos; he discussed cases with clerks in walks around the Supreme Court building).

${ }^{459}$ Roberts Supreme Court Hearings, supra note 5, at 203; see Roberts Alabama Speech, supra note 417 (recalling Rehnquist's admonition to make time for your children).

${ }^{460}$ Rehnquist FBI FOIA Request, 77-HQ-106904, Section 6, G.W. Medical Center, Discharge Summary, Aug. 8, 1980. 
during the summer of 1980 when the three of you acted more as medical interns than as law clerks."461

Roberts's clerkships could have not been more different. Friendly was a workaholic devoted to the law; Rehnquist viewed the law as a job that yielded to family time. Friendly was more open to his clerks' suggestions and, like Brandeis, often adopted them word for word; Rehnquist was less amenable to clerks' suggestions and less willing to change his mind. "Anyone who clerked for him was familiar with him intoning the phrase, "Well, I'm just not going to do it,"' Roberts recalled. "That meant that was the end of it, no matter how much you were going to try to persuade him. It wasn't going to happen."462 Roberts shared Friendly's "law intenseness."463 Roberts, however, was more of a political animal than Friendly and thrived in the Court's highly politicized atmosphere. Roberts enjoyed Friendly's intense and monastic process of crafting an opinion but also appreciated Rehnquist's more ideological approach. ${ }^{464}$

\section{Reagan Justice Department}

After his clerkships, Roberts embarked on a completely different career path than Friendly. Friendly's standard advice to his former clerks-not to spend too much time in the public sector before gaining litigation and corporate experience in private practice 465 _reflected his pre-judicial career in big law firms. Roberts, however, gained his formative legal experiences in the public sector.

Roberts embodied Brandeis and Frankfurter's dream for Harvard's top law graduates-highly credentialed, trained at the feet of great judges, and primed for public service. ${ }^{466}$ Whereas Brandeis prepared his clerks for academia and positions in Roosevelt's New Deal, Roberts entered public service as one of the legal foot soldiers in the Reagan Revolution. Reagan's November 1980 defeat of Jimmy Carter changed Roberts's career trajectory. Clerking for Rehnquist identified Roberts with the emerging conservative

${ }^{461}$ Letter from William Rehnquist to Dean Colson 1-2 (Oct. 1, 1981) (on file with Rehnquist Papers, Hoover Institution, Box 113, Folder 7 "Law Clerks 1979-1982").

462 Jeffrey Rosen, Roberts's Rules, THE ATLANTIC, Jan./Feb. 2007, at 112 [hereinafter Rosen, Roberts's Rules]. For a discussion of Roberts's Rehnquist clerkship, see generally Liptak \& Purdum, supra note 2.

463 See Scott, supra note 428, at 25.

464 See Roberts Supreme Court Hearings, supra note 5, at 202-03.

465 Edelman Interview, supra note 389.

466 See White, supra note 54. 
legal movement. One of the movement's goals included "the recruitment and mentoring of young conservative lawyers." 467

Near the end of his Rehnquist clerkship, the Reagan Justice Department approached Roberts about serving as a special assistant to Attorney General William French Smith. Special assistantships were the entrée to the corridors of Washington political power. Though nominally assisting Smith, Roberts reported to another Republican lawyer and future D.C. Circuit judge, Kenneth Starr.

At the Justice Department, Friendly and Rehnquist were in Roberts's thoughts. In March 1982, Roberts wrote a memo proposing reform of habeas corpus by eliminating Fay v. Noia's de novo review, including a one-year statute of limitations on habeas review, and abolishing federal habeas review of state death penalty cases. Such review, Roberts wrote, "makes a mockery of the criminal justice system." 468 Roberts later testified that his memo proposed to limit successive, unmeritorious habeas petitions clogging the federal system. ${ }^{469}$ At the time, he wrote Assistant Attorney General Jonathan C. Rose: "The attached memorandum contains some thoughts on habeas corpus reform, for whatever you think they're worth. Judge Friendly and Justice Rehnquist would never have forgiven me if I remained mute." 470

Roberts sent Friendly the memo, which quoted Friendly's law review article, Is Innocence Irrelevant?,471 arguing that Fay v. Noia should be overruled by legislation. "Please feel free to file it in the nearest wastebasket if that is your inclination," Roberts wrote Friendly, adopting the judge's modesty. "I certainly do not agree with everything in the proposal. Compromises had to be made in order to bring our ideas closer to those of our friends in Congress, who may, in any event, follow the above filing suggestion themselves." 472 Friendly responded that, "[d]espite the flattering quotation," Roberts's habeas proposal went "too far." ${ }^{\text {"473 }}$ Roberts's calls for

467 Steven M. Teles, Transformative Bureaucracy: Reagan's Lawyers and the Dynamics of Political Investment, 23 STUD. IN AM. POL. DEV. 61, 69 (2009). See generally STEVEN M. TELES, THE RISE OF THE CONSERVATIVE LEGAL MOVEMENT (2008).

468 Roberts Memo (Mar. 1982) (on file with author).

${ }^{469}$ See Roberts Supreme Court Hearings, supra note 5, at 432-35.

470 Roberts Memo, supra note 468.

471 See Friendly, supra note 370.

472 Letter from John G. Roberts to Henry J. Friendly (Mar. 18, 1982) (on file with Friendly Papers, supra note 72, Box 220, Folder 220-2).

${ }^{473}$ Letter from Henry J. Friendly to John G. Roberts (Apr. 2, 1981) (on file with Friendly Papers, supra note 72, Box 220, Folder 220-2); see also Letter from Henry J. Friendly to Assistant Attorney General Jonathan C. Rose (Apr. 2, 1981) (on file with Friendly Papers, supra note 72, Box 220, Folder 220-2); Letter from Assistant Attorney General Jonathan C. Rose to Henry J. Friendly (Mar. 24, 1982) (on file with Friendly Papers, supra note 72, Box 220, Folder 220-2). 
habeas reform, no doubt inspired by Friendly's article, were fourteen years ahead of their time. ${ }^{474}$

After eighteen months in the Justice Department, Roberts left in November 1982 to become Associate White House Counsel. Roberts wrote Friendly: "While I suspect you may be displeased that I have not yet found my way to a litigator's table in the courtroom, the legal issues surrounding the President are fascinating, and I am delighted to have the opportunity to explore them and serve an Administration whose objectives I share."475 Friendly, despite his warning about waiting too long to enter private practice, encouraged Roberts. "You certainly are needed in the White House," Friendly wrote, "I sometimes wonder whether this country has ceased to be governable by anyone." $" 476$

Friendly helped Roberts on issues of mutual interest such as torpedoing the National Court of Appeals or "intercircuit tribunal." Roberts wrote Friendly about pressure from Chief Justice Burger, Congress, and the Justice Department because of the Supreme Court's caseload of 150 cases per term. "In confidence, our office is fighting the good fight against it," Roberts wrote Friendly. "Our only hope is that Congress will continue to do what it does best-nothing." 477 Friendly responded with encouragement and a letter he had written to Rep. Robert Kastenmeier (D-WI) opposing the proposal. ${ }^{478}$ Roberts thanked Friendly for the Kastenmeier letter and assured Friendly that the Administration would go along with the National Court of Appeals only if it included "abolition of Supreme Court mandatory appellate jurisdiction, repeal of diversity jurisdiction, and restrictions on prisoner petitions ( $\$ 1983$ as well as habeas corpus) .... There will be peace in Lebanon before Congress repeals diversity jurisdiction or restricts prisoner petitions, so I think our position is fairly fixed."479 As Roberts predicted, the National Court of Appeals failed and repealing diversity jurisdiction never happened. For nearly four years, Roberts worked in a capacity at the White House Counsel's office familiar to Frankfurter and Brandeis during the New Deal

474 See Antiterrorism and Effective Death Penalty Act of 1996, 28 U.S.C. $\S \S 2261-$ 2266 (2006) (banning successive petitions, imposing one-year (or less) statute of limitations on initial petitions, and eliminating de novo review).

475 Letter from John G. Roberts to Henry J. Friendly (Feb. 3, 1983) (on file with Friendly Papers, supra note 72, Box 220, Folder 220-4).

476 Letter from Henry J. Friendly to John G. Roberts (Feb. 8, 1983) (on file with Friendly Papers, supra note 72, Box 220, Folder 220-4).

${ }^{477}$ Letter from John G. Roberts to Henry J. Friendly (Oct. 11, 1983) (on file with Friendly Papers, supra note 72, Box 220, Folder 220-6).

478 Letter from Henry J. Friendly to John G. Roberts (Oct. 18, 1983) (on file with Friendly Papers, supra note 72, Box 220, Folder 220-6).

479 Letter from John G. Roberts to Henry J. Friendly (Nov. 18, 1983) (on file with Friendly Papers, supra note 72, Box 220, Folder 220-6). 
and familiar to Rehnquist as head of Nixon's Office of Legal Counsel but foreign to Friendly-lawyer as political actor.

\section{Hogan \& Hartson}

In May 1986, Roberts entered private practice as an associate at Hogan \& Hartson, a move that would have pleased Friendly. Friendly, however, did not live to see it. Depressed about his beloved wife Sophie's death, completely blind, and in failing health in March 1986, the eighty-two-yearold Friendly committed suicide. ${ }^{480}$

Roberts, like Friendly, thrived in private practice (Roberts made partner in October 1987), but as a different type of lawyer. Whereas Friendly made a name for himself as a regulatory counsel and corporate litigator, Roberts joined the Supreme Court bar. ${ }^{481}$ Roberts found a new mentor in E. Barrett Prettyman Jr., a Democratic establishment figure, son of a D.C. Circuit judge, clerk to three Justices, and frequent Supreme Court advocate. Prettyman became Roberts's mentor and lunch partner. ${ }^{482}$ By emulating Prettyman, Roberts represented corporate clients, like Friendly, but strove to do so before the Court.

\section{Principal Deputy Solicitor General}

Roberts also became a leading member of the Supreme Court bar with help from his former Reagan Justice Department boss, Ken Starr. As George H.W. Bush's Solicitor General, Starr lured Roberts back to government to be Starr's principal deputy. Serving in the Solicitor General's office was the most opportune way to argue before the Court and to build a future Supreme Court practice. As Principal Deputy Solicitor General, Roberts decided whether the government should appeal adverse decisions. ${ }^{483} \mathrm{He}$ practiced law as social policy-making in ways that Friendly never imagined. For example, Roberts signed a brief arguing that Roe v. Wade was "wrongly

480 Kramer Interview, supra note 380; Paul Gewirtz, A Lawyer's Death, 100 HARV. L. REv. 2053, 2053-54 (1987).

481 Richard J. Lazarus, Advocacy Matters Before and Within the Supreme Court: Transforming the Court by Transforming the Bar, 96 GEO. L.J. 1487, 1499-1500 (2008); Michael Grunwald, Roberts Cultivated an Audience with Justices for Years, WASH. POST, Sept. 11, 2005, at A1.

482 Grunwald \& Goldstein, supra note 4.

483 Judge Roberts' Judiciary Committee Questionnaire, GPO ACCESS http://www.gpoaccess.gov/congress/senate/judiciary/sh 109-158/57-140.pdf [hereinafter Roberts Supreme Court Questionnaire]. 
decided." ${ }^{284} \mathrm{He}$ signed another brief arguing for the termination of courtordered school desegregation. ${ }^{485}$ These positions reflected the Administration's views and not necessarily Roberts's. It is a mistake, Roberts argued, to conflate zealous advocacy and agreeing with his client's views. ${ }^{486}$ Either way, his job landed him in the culture wars. Roberts's Solicitor General experience caught the attention of the first Bush Administration.

\section{D.C. Circuit}

In January 1992, George H.W. Bush nominated Roberts to replace Clarence Thomas on the D.C. Circuit. The thirty-seven-year-old Roberts would have been one of the Nation's youngest federal appellate judges. ${ }^{487}$ The Democrat-controlled Senate never held hearings or voted on Roberts's nomination before the 1992 presidential election. Senate Republicans blamed the Democrats. ${ }^{488}$ Democrats claimed the Bush Administration, which knew that nominations are not voted upon in presidential election years, failed to make a "really great push ... to make an exception for Mr. Roberts," and perhaps felt overconfident that Roberts could be re-nominated after Bush defeated Bill Clinton. ${ }^{489}$ Clinton's defeat of Bush dashed Roberts's hopes of a precocious start on the bench. Unfortunately for Roberts, Friendly was not around to push Roberts's confirmation as Frankfurter and Hand had done for Friendly. Friendly had written letters to New York's U.S. Senators and enlisted at least one former Friendly clerk to urge Leval's confirmation in 1977 as a judge in the Southern District of New York. ${ }^{490}$

Roberts turned disappointment into a blessing and found happiness in his personal life. In 1996, he married Jane Sullivan, a fellow Washington lawyer; they have two children, Josephine and Jack. Friends had worried that Roberts was married to the law much like Cardozo and, to a lesser extent, Friendly.

484 Brief for Respondent at 13, Rust v. Sullivan, 500 U.S. 173 (1990) (Nos. 89-1321,

485 Brief for United States as Amicus Curiae Supporting Respondents, Bd. of Educ. v. Dowell, 498 U.S. 237 (1991) (No. 89-1080).

486 Roberts D.C. Circuit Hearings, supra note 424, at 419.

${ }^{487}$ Roberts was thirty-six when Bush announced his nomination. Michael Luttig joined the Fourth Circuit at age thirty-seven; Alex Kozinski was Chief Justice of the Court of Federal Claims at age thirty-two and a Ninth Circuit judge by age thirty-five.

488 See Roberts D.C. Circuit Hearings, supra note 424, at 115.

489 See id. at 114

490 Letter from A. Raymond Randolph to Henry J. Friendly 1 (Apr. 4, 1977) (on file with Friendly Papers, supra note 72, Box 210, Folder 210-11) (informing Friendly that he had spoken to friends in Carter Justice Department); Letter from Pierre Leval to Henry J. Friendly (May 8, 1979) (on file with Friendly Papers, supra note 72, Box 219, Folder 219-4). 
Roberts, however, struck the work and family balance that Rehnquist had taught him. ${ }^{491}$ Roberts returned to Hogan \& Hartson in 1993 and joined a shortlist of Supreme Court advocates; the Justices regarded him as one of the best. ${ }^{492}$ Roberts won twenty-five of his thirty-nine Supreme Court arguments. ${ }^{493}$

On May 10, 2001, George W. Bush re-nominated Roberts to the D.C. Circuit, but the Democrat-controlled Senate again stalled the nomination. The Republicans retook the Senate on January 7, 2003, and Roberts, fortyeight, was confirmed five months later.

During his two years on the D.C. Circuit, Roberts often turned to Friendly's writings for inspiration and support. Roberts cited Friendly's law review articles and opinions in six of forty-nine D.C. Circuit opinions. ${ }^{494} \mathrm{Just}$ as he did in the Justice Department memorandum about reforming habeas corpus, Roberts "sometimes pressed Friendly into the service of agendas not exactly Friendly's own." 495 In one opinion, fellow Friendly clerk and D.C. Circuit Judge Merrick Garland accused Roberts of misreading Friendly's views. ${ }^{496}$

Roberts's description of the D.C. Circuit during his Supreme Court nomination hearings contained the same sort of judge-as-umpire idealization as his description of Friendly. Roberts described the D.C. Circuit as a court where "judges put aside those [political] ties and those views and become judges all focused on the same mission of vindicating the rule of law," where

${ }^{491}$ See Roberts Supreme Court Hearings, supra note 5, at 203.

492 Roberts D.C. Circuit Hearings, supra note 424, at 98 (Sen. Hatch said: "I have had Supreme Court Justices say you are one of the two greatest appellate lawyers living today, to me personally.").

493 Roberts Supreme Court Questionnaire, supra note 483, at 18-34.

494 See Taucher v. Brown-Hruska, 396 F.3d 1168, 1173-74 (D.C. Cir. 2005) (quoting Friendly, Quest for Reason, supra note 158, reprinted in FRIENDLY, BENCHMARKS, supra note 347, at 291, 294); United States ex rel. Totten v. Bombardier Corp., 380 F.3d 488, 495 (D.C. Cir. 2004) (quoting FRIENDLY, BENCHMARKS, supra note 347, at 216); In re England, 375 F.3d 1169, 1181-82 (D.C. Cir. 2004) (quoting FRIENDLY, BENCHMARKS, supra note 347, at 202); PDK Labs., Inc. v. U.S. Drug Enforcement Agency, 362 F.3d 786, 802, 809 (D.C. Cir. 2004) (Roberts, J., concurring in part and concurring in the judgment) (quoting Henry J. Friendly, More Definite Standards of Administrative Action: The Need, in FRIENDLY, BENCHMARKS, supra note 347, at 86, 97 and quoting Time, Inc. v. U.S. Postal Serv., 667 F.2d 329, 335 (2d Cir. 1981) (Friendly, J.)); Lemoyne-Owen College v. NLRB, 357 F.3d 55, 61 (D.C. Cir. 2004) (quoting FRIENDLY, BENCHMARKS, supra note 347, at 104); Ramaprakash v. FAA, 346 F.3d 1121, 1122 n.1 (D.C. Cir. 2003) (citing FRIENDLY, BENCHMARKS, supra note 347 , at 106).

495 Robert Gordon, Friendly Fire: How John Roberts Differs From His Hero and Mentor, SLATE (Aug. 11, 2005), available at http://www.slate.com/id/2124353.

496 See United States ex rel. Totten, 380 F.3d at 513 (Garland, J., dissenting). 
opinions were "almost always unanimous," and judges did not disagree "along political lines." 497 But often the unanimity of D.C. Circuit opinions depends on the composition of the three-judge panel. Roberts, for example, joined fellow Friendly clerk A. Raymond Randolph's majority opinion in the Hamdan detainee detention case that the Supreme Court subsequently reversed. ${ }^{498}$ Had he spent his entire judicial career on the D.C. Circuit, Roberts would have encountered more hot-button issues than Friendly did on the Second Circuit, but Roberts also might have lived up to his idealization of Friendly as a judicial umpire.

\section{FRIENDLY MYTHOLOGY REVISITED}

Near the end of Roberts's Supreme Court nomination hearings, Sen. Charles Schumer said the "fundamental question" was:

[W]hat kind of justice will John Roberts be? Will you be a truly modest, temperate, careful judge in the tradition of Harlan, Jackson, Frankfurter and Friendly? Will you be a very conservative judge who will impede congressional prerogatives but does not use the bench to remake society, like Justice Rehnquist? ${ }^{499}$

It is too early in Roberts's judicial career to draw any definitive conclusions. But, at least from a professional standpoint, the current answer is probably both.

From Rehnquist, Roberts learned to write minimalist opinions, to balance work and family, and to foster collegiality despite ideological disagreements. Roberts's role as Chief Justice has probably increased his admiration for Rehnquist. Roberts has praised Rehnquist's accomplishments as Chief Justice, who lacks authority over fellow Justices other than assigning opinions and presiding over oral argument. Roberts has credited Rehnquist with making oral argument less "freewheeling and free-ranging. . . . When he left the court, the arguments were more about law, which I think arguments to the court should be." 500 Roberts has acknowledged that as Chief Justice

497 Roberts Supreme Court Hearings, supra note 5, at 254. Roberts cited Friendly and concurred in a D.C. Circuit case because "the cardinal principle of judicial restraint-if it is not necessary to decide more, it is necessary not to decide morecounsels us to go no further." PDK Labs, 362 F.3d at 799 (Roberts, J., concurring in part and concurring in the judgment).

${ }^{498}$ Hamdan v. Rumsfeld, 415 F.3d 33 (D.C. Cir. 2005), rev'd, 548 U.S. 557 (2006).

499 Roberts Supreme Court Hearings, supra note 5, at 442.

500 John Flowers, Chief Justice Speaks at Middlebury College, ADDISON CTY. IND., Oct. 26, 2006; see also Adam Gorlick, Chief Justice Roberts Dedicates Stanford Law School's Rehnquist Courtyard, STANFORD REP., Oct. 23, 2009 ("Before him, arguments and briefs before the court were more free wheeling .... Chief Justice Rehnquist's 
Rehnquist "changed" from Roberts's clerkship when Rehnquist was more of a "Lone Ranger."501 Roberts also admires Rehnquist's legal contributions. "He changed the way that law is considered," Roberts said in October 2009. "Historians will not overlook Chief Justice Rehnquist. They will talk about the effect of his presence on the court in strengthening the concept of federalism in the Constitution, in giving meaning to the concept of separation of powers and refining our notions of criminal law and procedures." 502

Friendly's influence on Roberts should not be underestimated. ${ }^{503}$ From Friendly, Roberts learned to take pride in judicial craftsmanship, to provide elaborate reasoning and bring intellectual rigor to each opinion, and to reason one's way to a result. In many ways, Friendly remains Roberts's intellectual ideal. Roberts's descriptions of Friendly and Rehnquist in his Supreme Court questionnaire are revealing:

I was fortunate to have two appellate clerkships immediately after law school. Judge Henry J. Friendly is justly remembered as one of this Nation's truly outstanding federal appellate judges. The clerkship on the Supreme Court for then-Associate Justice Rehnquist the following year was an intensive immersion in the federal appellate process at the highest level. ${ }^{504}$

The first description praises Friendly the judge; the second praises the Court as an institution.

Friendly's influence on Roberts derives in part from coming first. Friendly introduced Roberts to the federal judiciary and its traditions.

approach in his opinions and his approach at oral argument focused on the more concrete building blocks of the law - the language of a statute or a constitutional provision and the court's precedence [sic] in the particular area."); Adam Liptak, Sidebar: Judging a Court with Ex-Judges Only, N.Y. TIMES, Feb. 17, 2009, at A14 (quoting Roberts that "the method of analysis and argument shifted to the more solid grounds of legal arguments. What are the texts of the statutes involved? What precedents control? ... [leading to] a more legal perspective than a policy perspective").

${ }^{501}$ Rosen, Roberts's Rules, supra note 462, at 112 ("I think there's no doubt that he changed, as associate justice and chief; he became naturally more concerned about the function of the institution.").

502 Gorlick, supra note 500. Compare JEFFREY ROSEN, THE SUPREME COURT 220 (2007) (contending Roberts "appears to share many of the former chief's qualities of temperament and jurisprudence" and eschews originalism for a "bottom-up" approach to judging), with Simon Lazarus, More Polarizing Than Rehnquist, AM. PROSPECT, May 2007, at 23 (arguing "the Roberts Court's actual performance draws quite a different picture from its chief's off-the-court presentations").

503 Daniel Breen, Avoiding "Wild Blue Yonders": The Prudentialism of Henry J. Friendly and John Roberts, 52 S.D. L. REV. 73 (2007); Laura Ray, The Style of a Skeptic: The Opinions of Chief Justice Roberts, 83 IND. L.J. 997, 1012-13 (2008).

504 Roberts Supreme Court Questionnaire, supra note 483, at 16. 
Friendly, having clerked for Brandeis, learned from Frankfurter and Harlan, and sat with Hand, considered himself part of a sacred order. ${ }^{505}$ Roberts also sees himself as coming from this same grand tradition, admiring Chief Justice John Marshall's leadership, ${ }^{506}$ Justice Jackson's writing, ${ }^{507}$ and Justice Brennan's collegiality. ${ }^{508}$ Roberts wanted to unite the Court and decrease the number of 5-4 decisions. ${ }^{509} \mathrm{He}$ often writes with a Holmesian skepticism, fondness for epigrams, and sense of humor. ${ }^{510}$

Roberts's writing process reflects the modern realities of clerkships. Roberts, like most Justices, employs four law clerks. By contrast, Gray and Brandeis hired one clerk per Term; Friendly hired one and eventually two; Rehnquist hired three. Clerks, moreover, are more ideologically identified with their judges and more accustomed to drafting opinions. Despite these institutional changes, Roberts has incorporated lessons that Friendly learned from Brandeis and that Roberts learned from Friendly. But the professional influences of an alternative judicial genealogy beginning with Jackson and Rehnquist are there, too. Roberts described his writing process to C-SPAN:

I write [the opinions] out longhand. I have law clerks help if there is something I think they could write part of-you know, "I feel comfortable with this, so you go ahead and draft something up," that I will then heavily edit. If it's a new area that I don't feel I know about, I try to do that myself to make sure I'm getting it right. I like to do a lot of the facts myself, because I think they're very important. And certainly by the time the opinion is done, I don't put it to bed until I feel comfortable that it's - that it's my work. ... it's an ongoing process. You write a first draft. You figure out, "Well, I need to know a little bit more about how this case fits in." You

505 See supra text accompanying note 340 .

506 Rosen, Roberts's Rules, supra note 462, at 106 ("Roberts decided early in his first term to embrace Marshall as a model.").

507 Roberts Supreme Court Hearings, supra note 5, at 385 ("One of the reasons I've given previously for admiring Justice Jackson is he was one of the best writers the court has ever had ....").

508 Compare Maura Reynolds, Judge Roberts' View From the Bench, L.A. TIMES, Aug. 10, 2005, at A9 (citing February 2005 speech praising Jackson's writing style, Frankfurter and Harlan's "analytical clarity," Brennan's "collegiality," and then-Chief Justice Rehnquist), with Roberts D.C. Circuit Hearings, supra note 424, at 437-38 ("As a general matter, I admire the judicial restraint of Holmes and Brandeis, the intellectual rigor of Frankfurter, the common sense and pragmatism of Jackson, the vision of John Marshall. But I would not say that there is one Justice's judicial philosophy that I would strive to copy.").

509 See Rosen, Roberts's Rules, supra note 462, at 105.

510 Ray, supra note 503, at 1013-15 (comparing Roberts's "skepticism" and "epigrammatic statements" to Holmes's); see, e.g., Pennsylvania v. Dunlap, $129 \mathrm{~S}$. Ct. 448, 448 (2008) (Roberts, C.J., dissenting from denial of certiorari) ("North Philly, May 4, 2001. Officer Sean Devlin, Narcotics Strike Force, was working the morning shift.”). 
go back and read the case. You're always going back and looking at the briefs, always bringing the law clerks in and bouncing ideas off of them"What's wrong with it?" It's sort of the continuation of the oral argument process-“What's wrong with this? What's the answer to that?" ... in my case, I like to do a lot of different drafts. Twenty drafts, twenty-five drafts it's not unusual, changing one thing in one draft and changing something else; sometimes changing it back, and then changing it back again. . . I like the writing process, so I enjoy that. ${ }^{511}$

Like Brandeis, Roberts understands the importance of facts and writes many drafts. Like Brandeis and Friendly, Roberts writes most of his opinions himself in longhand and takes great pride in judicial craftsmanship. Like Friendly and Rehnquist, Roberts does not require that clerks write bench memos and uses his clerks as sounding bounds. ${ }^{512}$ Like Jackson, Roberts displays a fondness for epigrams. And like Rehnquist, he delegates some drafting to his law clerks.

If clerkship genealogies reveal a future judge's DNA, then Friendly and Rehnquist are the two strands of Roberts's double-helix. Friendly avoided constitutional questions, deferred to elected officials, and respected precedent. Rehnquist tried to empower the states at the expense of the federal government, overruled federal statutes, and was less respectful of precedent.

The more interesting question is why Roberts has gone to great lengthswith friends and law clerks, in his D.C. Circuit opinions, and most prominently during his Supreme Court nomination hearings-to portray himself as a Friendly disciple.

\section{A. Friendly as Umpire}

During his Supreme Court nomination hearings, Roberts described Friendly as the impartial judicial umpire whom Roberts aspired to be. Roberts told the Senate Judiciary Committee that he admired Friendly's "total commitment to excellence in his craft" and described how "editorialists of the day couldn't decide whether he was a liberal or a conservative." $513 \mathrm{He}$ admired that Friendly was not results-oriented and recalled that Friendly once had circulated a dissent because the majority's position he had been assigned "was not right." $514 \mathrm{He}$ admired the authoritativeness of Friendly's opinions, which Friendly accomplished not

511 Interview by Susan Swain with John G. Roberts, in Washington, D.C. (June 19, 2009), available at http://www.c-spanvideo.org/program/286078.

512 Roberts Alabama Speech, supra note 4.17.

513 Roberts Supreme Court Hearings, supra note 5, at 202.

514 Id. 
through a Holmesian turn-of-phrase but through a Brandeisian rigor. ${ }^{515}$ Roberts said:

[Friendly] doesn't just sort of, you know, knock the pieces off the board. He marches through in a very careful way to let you know exactly how he reached the decision, why he went this way if there was a difference among the precedents, why he chose that one if there was a question of who has the responsibility, why he went that way, and lays it all out in such a way that you can understand the result.

To this day, lawyers will say, when they get into an area of the law and they pick up one of his opinions, that you can look at it and it's like having a guide to the whole area of the law. 516

Finally, Roberts described Friendly as "an absolute genius.... I think everybody would have agreed we would have a better result if we just let him make the decision, regardless of what it was. But he had the essential humility to appreciate that he was a judge, and that this decision should be made by this agency or this decision by that legislature." 517

Friendly exemplified Roberts's conception of judicial modesty. Asked to describe judicial modesty, Roberts said:

Judges have to have the humility to recognize that they operate within a system of precedent shaped by other judges equally striving to live up to the judicial oath, and judges have to have the modesty to be open in the decisional process to the considered views of their colleagues on the bench. 518

\section{B. Friendly as Unattainable Ideal}

Friendly is an unattainable ideal for Roberts because they took different career paths to the bench, served on different courts, and judged in different eras.

Friendly spent his entire pre-judicial career in private practice as a corporate litigator rather than an ideologue. Although he represented many corporations at Hogan \& Hartson, Roberts defined his legal career on the front lines of the conservative legal movement. His formative legal

515 Id.

516 Id. at $202-03$.

$517 \mathrm{Id}$. at 202.

518 Id. at 55 . Roberts described a "modest judge" as understanding "the role of the judge is limited," "respect for precedent," and "being open to the considered views of your colleagues." Id. at 158 . On judicial modesty, see Roberts Supreme Court Questionnaire, supra note 483, at 66-67. 
experiences were serving in the Reagan Justice Department and White House Counsel's Office and spearheading the conservative legal agenda as the principal deputy in the Bush I Solicitor General's office under Ken Starr. Service in two Republican administrations reaffirmed Roberts's belief in using the law to change policy and trumped the lessons of deference to elected officials and respect for precedent that he had learned with Friendly.

In some ways, the Friendly-Roberts comparison is unfair because they served on different courts. Friendly was a Second Circuit judge who had to defer to Supreme Court and Second Circuit precedent or face the threat of reversal by the Court or en banc. Friendly's decisions were final ninety-nine percent of the time, but he was never sure which ones. Friendly also never addressed many of the hot-button social, political, and economic issues that reach the Court.

No one on the current Court practices the judicial restraint of Holmes, Brandeis, or Friendly. Perhaps judicial restraint is incompatible with the Court's role in American society since Brown v. Board of Education. Although the failed enforcement of Brown revealed the limits of the Court as an engine for social or political change, the "legal liberalism" 519 of the Warren Court has persisted with the Burger Court, the Rehnquist Court, and the Roberts Court. Roberts's image of Friendly's avoiding of constitutional questions, deferring to elected officials, and respecting precedent sadly seems like an anachronism.

\section{Friendly v. Rehnquist}

Several of Roberts's recent high-profile opinions illustrate the difficulties of living up to his ideal vision of judging like Friendly. A headline writer characterized Citizens United as "Roberts versus Roberts," 520 but based on Roberts's judicial genealogy, his high-profile opinions might be more accurately described as Friendly v. Rehnquist.

Roberts's plurality opinion in Parents Involved in Community Schools (PICS) reflects Rehnquist's influence, not Friendly's. ${ }^{521}$ Invalidating the race-based school assignment plans in Seattle and Louisville, Roberts followed Rehnquist's majority opinion in Gratz and Rehnquist's dissent in

519 KALMAN, supra note 31, at 2 (using "the term legal liberalism to refer to trust in the potential of courts, particularly the Supreme Court, to bring about 'those specific social reforms that affect large groups of people such as blacks, or workers, or women, or partisans of a particular persuasion; in other words, policy change with nationwide impact"').

520 Jeffrey Rosen, Roberts Versus Roberts, THE NEW REPUBLIC, Mar. 11, 2010, at 17, available at http://www.tnr.com/article/politics/roberts-versus-roberts [hereinafter Rosen, Roberts Versus Roberts].

${ }^{521}$ Parents Involved in Cmty. Sch. v. Seattle Sch. Dist. No. 1, 551 U.S. 701 (2007). 
Grutter. Roberts refused to follow controlling precedent in Grutter, 522 distinguishing affirmative action in graduate schools from primary and secondary schools. ${ }^{523}$

In a very un-Brandeis move, Roberts refused to defer to the decisions of elected school board officials in Seattle and Louisville to make race one factor in assigning students. Roberts selectively quoted from briefs of Brown plaintiffs to portray the PICS dissenters' deferential position as similar to that of segregationists in Brown, a comparison that lacked the historical context of a Brandeis brief, one of Friendly's scholarly articles, or the prize-winning papers of a former Harvard history major. ${ }^{524}$ Roberts punctuated his PICS opinion with a Jacksonian epigram: "The way to stop discrimination on the basis of race is to stop discriminating on the basis of race." 525 Friendly never would have written such a phrase. ${ }^{526}$ Neither Brandeis nor Friendly championed racial issues. 527 Friendly, though he agreed with the outcome in Brown, ${ }^{528}$ believed that its lack of clear principle led to legal liberalism run amok in Roe. ${ }^{529}$ Like Roe, Roberts's PICS opinion perpetuated legal liberalism and trampled on the power of state and local elected officials.

Friendly's (and Brandeis's) influence is most evident in Roberts's majority opinion in Northwest Austin Municipal Utility District No. One v. Holder (NAMUDNO). ${ }^{530}$ Roberts took a Brandeisian approach of avoiding constitutional questions. ${ }^{531}$ Rather than address plaintiff's argument about the unconstitutionality of $\S 5$ of the Voting Rights Act, Roberts ruled for the plaintiff on statutory grounds. He broadly read the Act's bailout provision in $\S 4$ to include a "utility district" within the definition of a "political subdivision," 532 a reading that arguably contradicts one of the Court's

522 See id. at $740-41$.

523 See id. at $724-25$.

524 See id. at 746-48; Joel K. Goldstein, Not Hearing History: A Critique of Chief Justice Roberts's Reinterpretation of Brown, 69 OHIO ST. L.J. 791 (2008) (criticizing Roberts's selective quotation from Brown briefs in Parents Involved).

525 Parents Involved, 551 U.S. at 748.

526 See Friendly-Epsteins Interview, supra note 72, pt. VII, side 2, at 3.

527 See Christopher Bracey, Louis Brandeis and the Race Question, 52 ALA. L. REV. 859, 861 (2001); supra text accompanying note 376 (quoting Friendly about Thurgood Marshall).

528 Boudin, Madison Lecture, supra note 246, at 993-94; Henry J. Friendly, The Public-Private Penumbra-Fourteen Years Later, 130 U. PA. L. REV. 1289, 1292 (1982) (defending result in Shelley v. Kraemer and analogizing to Brown).

529 See Friendly, supra note 373, at 29-42.

530129 S. Ct. 2504, 2508 (2009).

531 Id. at 2508.

$532 \mathrm{Id}$. at 2513-2517. 
precedents. ${ }^{533}$ Despite its somewhat strained statutory interpretation and reading of precedent, Roberts's opinion channels Friendly's judicial modesty and incrementalism by explicitly deferring to Congress. ${ }^{534}$ It also garnered eight votes. Roberts, however, may have written a more minimalist opinion not because of Friendly's influence but because Roberts did not have five votes (or at least the vote of Justice Kennedy) to invalidate $\S 5$ of the Voting Rights Act on broad constitutional grounds. 535

Roberts's concurring opinion in Citizens United reveals his willingness to depart from Brandeis and Friendly's avoidance of constitutional decisions, deference to Congress, and respect for precedent. ${ }^{536}$ Roberts acknowledged that the Court usually seeks to avoid constitutional questions and to defer to Congress. ${ }^{537}$ Unlike $N A M U D N O$, where the plaintiff had raised alternative statutory and constitutional arguments, Citizens United agreed to dismiss its facial challenge to the McCain-Feingold Law in the lower courts. ${ }^{538}$ The Court took the unusual step of asking for reargument on constitutional issues not decided or even raised below.

Roberts could have avoided constitutional questions in Citizens United in several ways. He could have determined that the facial constitutional challenge had been waived. He could have decided the case on statutory grounds that the corporate campaign finance law did not apply to video on demand, ${ }^{539}$ a somewhat strained reading of the statute but no more strained than his statutory reading in NAMUDNO. Roberts invoked Brown as a reason not to adhere to stare decisis. ${ }^{540}$ And in a possible warning shot against Roe and Casey, he contended that stare decisis is "diminished.... when the precedent's validity is so hotly contested that it cannot reliably function as a basis for decision in future cases ...."541 His Citizens United concurrence reads more like a Rehnquist-type opinion that justified overruling two Supreme Court precedents and invalidating corporate spending limits in the McCain-Feingold Act, not a Friendly-type opinion that avoided

533 Id. at 2515 (citing City of Rome v. United States, 446 U.S. 156, 167 (1980) (limiting definition of political subdivision to "state")).

534 Id. at 2513 (quoting Blodgett v. Holden, 275 U.S. 142, 147-148 (1927) (Holmes, J., concurring)).

535 Rosen, Roberts Versus Roberts, supra note 520.

536 Citizens United v. Fed. Elections Comm'n, 130 S. Ct. 876, 917 (2010) (Roberts, C.J., concurring).

${ }^{537}$ Id. at 930-31 (quoting Blodgett v. Holden, 275 U.S. 142, 147-148 (1927)

(Holmes, J., concurring) and citing Ashwander v. TVA, 297 U.S. 288, 346 (1936)

(Brandeis, J., concurring)).

538 Id. at 892 (majority opinion).

$539 \mathrm{Id}$. at 887.

${ }^{540} \mathrm{Id}$. at 920 (Roberts, C.J., concurring).

${ }^{541}$ Id. at 921 (Roberts, C.J., concurring). 
constitutional questions, respected precedent, and deferred to elected officials.

Three years earlier, Roberts had distinguished one of the campaign finance precedents later overruled in Citizens United, and Justice Scalia had charged Roberts with engaging in "faux judicial restraint." 542 Perhaps from 2007 to 2009, Roberts engaged in Friendly's judicial incrementalism. Or perhaps, from the perspective of the ACLU and others, Roberts's Citizens United concurrence championed freedom of speech. ${ }^{543}$ Roberts's protection of free speech, however, is decidedly mixed. ${ }^{544}$

Roberts's majority opinion in $P C A O B$ is more minimalist than Citizens United. $P C A O B$ did not strike down the entire Sarbanes-Oxley Act or enjoin the Public Company Accounting Oversight Board, severing only the statute's double for-cause removal provision of board members as a violation of separation of powers. ${ }^{545}$ Yet the majority could have avoided constitutional questions by forcing the plaintiff to exhaust its administrative remedies or through an alternative reading of an underlying statute. ${ }^{546}$ No precedent required Roberts to overturn part of the statute. ${ }^{547}$ And, even though Roberts feared "a government ... ruled by functionaries" 548 and invoked the Constitution as "adopted to enable the people to govern themselves, through their elected leaders," Roberts instead opted for government by an unelected and unaccountable judiciary. In severing the for-cause removal provision, he

542 Fed. Election Comm'n v. Wis. Right to Life, Inc., 551 U.S. 449, 499 n.7 (2007) (Scalia, J., concurring in part and concurring in the judgment).

543 See Floyd Abrams \& Ronald Dworkin, Letters to the Editor, "The Devastating" Decision: An Exchange, N.Y. REV. OF Books, Apr. 29, 2010, at 65.

544 Compare United States v. Stevens, 130 S. Ct. 1577, 1586, 1592 (2010) (invalidating federal statute banning depictions of animal cruelty and limiting exceptions to First Amendment to historically-recognized categories), with Morse v. Frederick, 551 U.S. 393, 397 (2007) (upholding student suspension for displaying "Bong Hits 4 Jesus" banner off school property), and Rumsfeld v. Forum for Academic \& Inst. Rights, 547 U.S. 47, 60 (2006) (rejecting challenge to Solomon Amendment banning federal funding for universities that restrict access to military recruiters in part by distinguishing conduct from speech).

545 Free Enter. Fund v. Pub. Co. Accounting Oversight Bd., 130 S. Ct. 3138, 3161 (2010) (severing the unconstitutional provision).

546 Compare id. at 3150-51 (rejecting jurisdictional challenge based on statutory exhaustion requirement), with id. at 3182 (Breyer, J., dissenting) (observing "a plaintiff need not even first exhaust his administrative remedies"), and id. at 3182-84 (Breyer, J., dissenting) (arguing that there is no for-cause provision regarding SEC commissioners and that the majority opinion violates Ashwander's constitution avoidance principles).

${ }^{547}$ Id. at 3166-67 (Breyer, J., dissenting) (arguing "this Court's precedent . . . . does not clearly invalidate the provision in dispute" and that Humphrey's Executor and subsequent cases "expressly disapproved most of Myers ' broad reasoning").

$548 \mathrm{Id}$. at 3156. 
rewrote a statute passed by the House and Senate and signed by the President. Roberts's minimalist holding in $P C A O B$ seems Friendly-esque, but his inability to avoid constitutional questions and defer to elected officials is not. His willingness to rewrite an act of Congress to make a theoretical point about the scope of executive power seems more reminiscent of Rehnquist's opinions about federalism. ${ }^{549}$

It remains much too soon to tell whether Roberts's future opinions will channel Friendly's modesty and incrementalism like in NAMUDNO or reflect Rehnquist's less deferential approach to elected officials like in PICS, Citizens United, and to a lesser extent $P C A O B$. After all, Roberts has only sat on the Court for five years. Rehnquist's first five years on the Court were much different than his last five years. ${ }^{550}$ It is too simplistic, moreover, to define Roberts by only a handful of opinions or by either Friendly or Rehnquist. Any definitive conclusions about Roberts's jurisprudence must await a lifetime of his opinions as Chief Justice.

The most interesting thing about Roberts's clerkships is the mythology he has constructed about himself as a Friendly disciple and about Friendly as the sophisticated judicial umpire. Before the Senate Judiciary Committee, Roberts invoked Friendly as a rhetorical strategy to get confirmed and to project an image of fairness and impartiality. In some ways, Roberts's comments about Friendly are no different than Justice Sonia Sotomayor repeatedly telling the Senate Judiciary Committee that "a judge's job 'is not to make law' but 'to apply the law" 551 or President Obama calling for bipartisanship and then passing his health care legislation entirely through Democratic votes.

If anything, Roberts's idealization of Friendly shows him to be a master strategist much like the historical figure he often invokes-Chief Justice John Marshall. 552 Roberts cloaks himself as a Friendly disciple, then Roberts pursues the same conservative legal goals that he worked for as a Justice Department lawyer. The parallels between Roberts and Marshall continue if one considers Roberts locked in an ideological battle over the Constitution

549 See John Elwood, Free Enterprise Fund: The Lopez of Separation of Powers Doctrine, THE VOLOKH CONSPIRACY (June 28, 2010, 12:31 PM), http://volokh.com/2010/06/28/free-enterprise-fund-the-lopez-of-separation-of-powersdoctrine (comparing Roberts's PCAOB opinion to Rehnquist's opinion in Lopez because of their minimal practical impact).

${ }^{550}$ Reva Siegel, You've Come A Long Way, Baby: Rehnquist's New Approach to Pregnancy Discrimination in Hibbs, 58 STAN. L. REV. 1871, 1873 (2006).

551 Peter Baker and Neil A. Lewis, Judge Focuses on Rule of Law at the Hearings, N.Y. TIMES, July 14, 2009, at Al.

552 Rosen, Roberts's Rules, supra note 462 (expressing admiration for Marshall); Roberts Alabama Speech, supra note 417 (recommending biography of John Marshall to law students). 
with President Obama, much like the battles over the Constitution between Marshall and Jefferson. ${ }^{553}$ If Obama's comments about Citizens United at the State of the Union Address and Roberts's remarks at the University of Alabama are any indication, ${ }^{554}$ future cases about financial regulation and the constitutionality of the health care mandate could pit the Roberts Court against the Obama Administration. Perhaps a constitutional showdown will be avoided because of Roberts's desire to emulate his judicial idol, Henry Friendly.

Roberts's admiration for Friendly is heartfelt and genuine; the bond between them is everlasting. On May 15, 2010, Roberts hosted a reunion for former Friendly clerks at the Supreme Court. ${ }^{555}$ Second Circuit Judge Pierre Leval presented the Chief Justice with Friendly's judicial robe, which Friendly's family had given to Leval after Friendly's death. Leval said: "The Judge would have wanted Roberts to have it." 556

\section{CONCLUSION}

Judicial genealogy explores the professional influence of judges on law clerks. Friendly's clerkship with Brandeis and Roberts's clerkship with Friendly inspired them to become judges. As clerkships have become more widespread, the federal judiciary is increasingly composed of former clerks. ${ }^{557}$ Most clerks, however, do not become judges. Whether they choose private practice, public service, or the academy, clerks can learn valuable professional lessons from their judges about pride of craftsmanship, judicial decision-making, legal ethics, and possible career paths. The prestige, proliferation, and power of clerkships have changed over time to reflect an increasingly bureaucratic government, the complex nature of the law, and a professionalized judiciary. The constant is the intergenerational bond between judges and clerks.

Judicial genealogy also matters because, as the clerkships of Brandeis, Friendly, and Roberts show, law clerks tend to idealize their judges. This clerkship mythology, combined with the emergence of clerkships as musthave credentials, promotes a culture of judicial supremacy. The first time

553 Jeffrey Toobin, No More Mr. Nice Guy, NEW YORKER, May 25, 2009, at 42, 51 (suggesting a Roberts-Obama fight over the Constitution); Jeffrey Rosen, POTUS $v$. SCOTUS, THE NEW REPUBLIC, Mar. 16, 2010, available at http://www.tnr.com/article/politics/potus-v-scotus (making a similar connection and adding parallels to Marshall and Jefferson and Lincoln and Taney).

554 Roberts Alabama Speech, supra note 417 ("To the extent the state of the union has degenerated into a political pep rally, I don't see why we're there.").

555 Boudin Interview, supra note 448; Leval Interview, supra note 401.

${ }^{556}$ Leval Interview, supra note 401.

557 See infra app. 1. 
many lawyers wield power over people's lives is during clerkships. Clerks often work for judges who still believe in courts as engines of social or political change despite how the aftermath of Brown v. Board of Education discredited this idea of legal liberalism. Legal liberalism persisted not only during the Warren Court but also during the Burger Court with Roe v. Wade and the Rehnquist Court's efforts to realign the balance of power between the federal government and the states. Perhaps the Roberts Court's countermajoritarian decision in Citizens United will subject legal liberalism to another reappraisal. By encouraging top graduates to begin their careers as clerks, law professors may be sending the wrong message about the relative importance of judicial power. Some scholars have advocated a congressional clerkship program to provide balance. ${ }^{558}$ Judicial clerkships, however, are institutionally entrenched in American legal culture. Clerks need to realize that they can learn valuable professional lessons from their judges but that their judges are not gods and the judiciary should not be viewed as the mountaintop.

558 Dakota S. Rudesill, Closing the Legislative Experience Gap: How a Legislative Law Clerk Program Will Benefit the Legal Profession and Congress, 87 WASH. U. L. REV. 699, 703 (2010) (citing Letter from Dean Larry Kramer et al., to Sen. Arlen Spector, Chairman, Senate Judiciary Comm., and Rep. James Sensenbrenner, Chairman, House Judiciary Comm. (July 20, 2005)); Robin West, A Response to Goodwin Liu, 116 YALE L.J. POCKET PART 157, 161-62 (2006), available at http://thepocketpart.org/yljonline/constitutional-law/79-a-response-to-goodwin-liu. 
APPENDIX 1

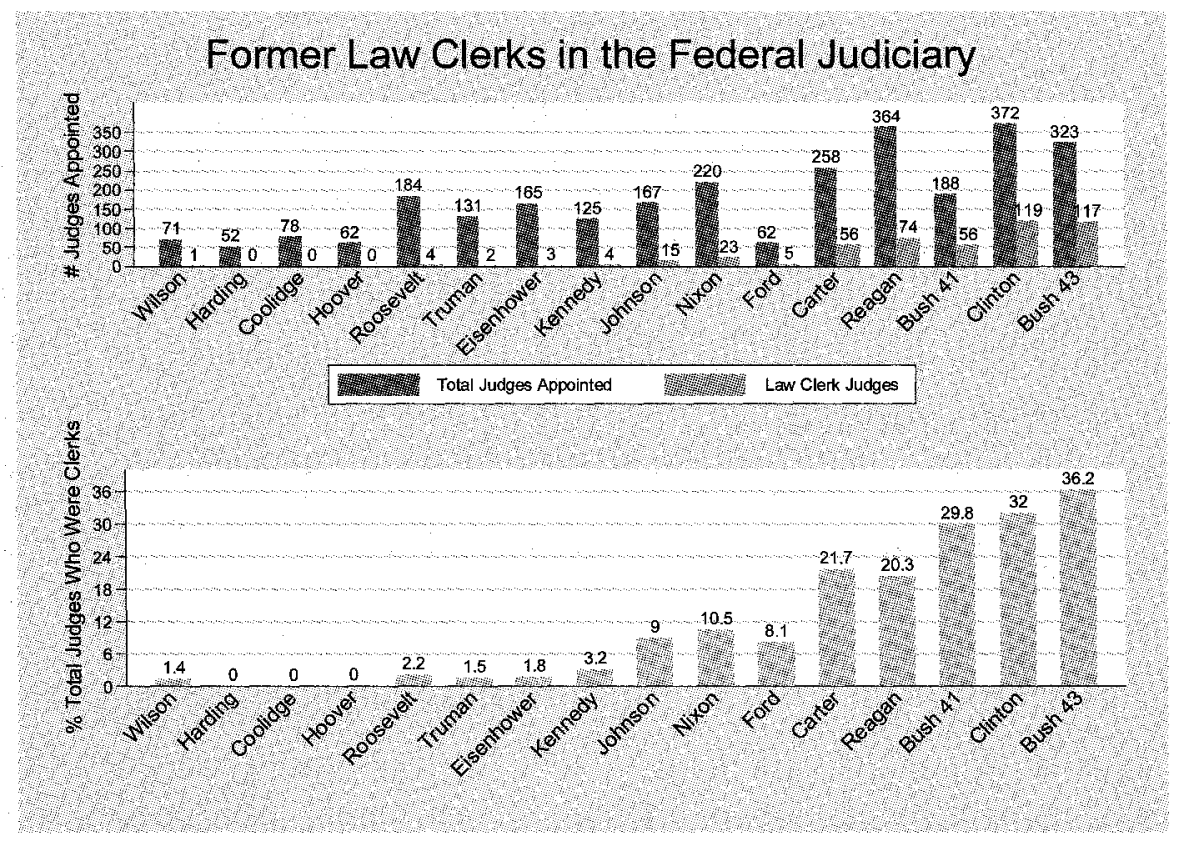

The Federal Judicial Center supplied the raw data, which is available on its website: http://www.fjc.gov/public/home.nsf/hisj. Only Article III judges confirmed by the Senate are included. Judges nominated to two different courts by the same President are only counted once. 
